UNIVERSIDADE DE SÃO PAULO

PROGRAMA DE PÓS-GRADUAÇÃO INTERUNIDADES EM BIOENGENHARIA ESCOLA DE ENGENHARIA DE SÃO CARLOS - FACULDADE DE MEDICINA DE RIBEIRÃO PRETO - INSTITUTO DE QUÍMICA DE SÃO CARLOS

DANIELA VIEIRA

Obtenção e caracterização de biocompósitos formados a partir de hidroxiapatita sintética e fibroína de seda na forma de blocos para enxerto ósseo

SÃO CARLOS 


\section{DANIELA VIEIRA}

Obtenção e caracterização de biocompósitos formados a partir de hidroxiapatita sintética e fibroína de seda na forma de blocos para enxerto ósseo

\section{VERSÃO CORRIGIDA}

(Versão original encontra-se na unidade que aloja o Programa de Pós-graduação)

Dissertação de mestrado apresentada ao Programa de Pós-Graduação Interunidades Bioengenharia -

Escola de Engenharia de São Carlos / Faculdade de Medicina de Ribeirão Preto / Instituto de Química de São Carlos da Universidade de São Paulo como parte dos requisitos para a obtenção do título de mestre em Ciências.

Área de Concentração: Bioengenharia Orientador: Prof. Dr. Sérgio A. Yoshioka

\section{SÃO CARLOS}




\section{AUTORIZO A REPRODUCÃO TOTAL OU PARCIAL DESTE TRABALHO POR QUALQUER MEIO CONVENCIONAL OU ELETROONICO, PARA FINS DE ESTUDO E PESQUISA, DESDE QUE CITADA A FONTE.}

Ficha catalográfica elaborada pela Biblioteca Prof. Dr. Sérgio Rodrigues Fontes da EESC/USP com os dados inseridos pelo(a) autor(a).

V657o

Vieira, Daniela

Obtenção e caracterização de biocompósitos formados a partir de hidroxiapatita sintética e fibroina de seda na forma de blocos para enxerto ósseo / Daniela Vieira; orientador Sérgio A. Yoshioka. Săo Carlos, 2018.

Dissertação (Mestrado) - Programa de Pós-Graduação Interunidades em Bioengenharia e Área de Concentração em Bioengenharia -- Escola de Engenharia de São Carlos; Faculdade de Medicina de Ribeirão Preto; Instituto de Quimica de Săo Carlos, da Universidade de Săo Paulo, 2018 .

1. Biocompósito. 2. Fibroina de seda. 3. Hidroxiapatita. 4. Regeneraçăo ossea. 5. Engenharia de tecido. I. Titulo.

Eduardo Graziosi Silva - CRB - 8/8907 
Nome: VIEIRA, Daniela

Título: Obtenção e caracterização de biocompósitos formados a partir de hidroxiapatita sintética e fibroína de seda na forma de blocos para enxerto ósseo

Dissertação apresentada ao Programa de Pós-Graduação Interunidades Bioengenharia - Escola de Engenharia de São Carlos / Faculdade de Medicina de Ribeirão Preto / Instituto de Química de São Carlos da Universidade de São Paulo como parte dos requisitos para a obtenção do título de mestre em Ciências.

\section{FOLHA DE JULGAMENTO}

\section{Candidato(a): Danicla Vieira \\ Titulo: "Obtençào e caracterizaçlo de biocompósitos formados a partir de hidroxiapatita sintética e fibroina de seda na forma de blocos para enxerto ósseo"}

Comissåo Julgadora

Prof(a). Dr(a). Sérgio Akinobu Yoshioka EESCIUSP

Prof(a), Dr(a). Alessandra de Almeida Lucas UFScar

Prof(a), Dria) Miguel Ángel Ramirez Gil UNESP

Prof(a). Dr(a). Rafael Salomaio EESCIUSP
Assinatura
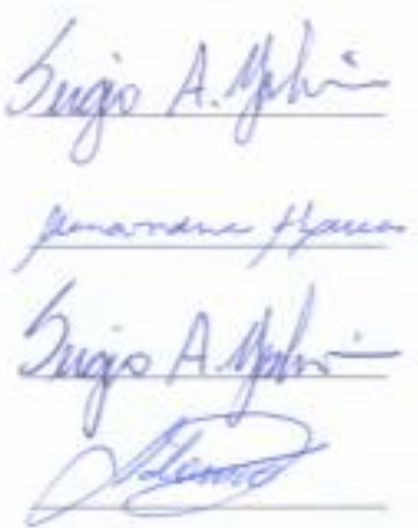

Resultade

Nå Votante

APROVAD4

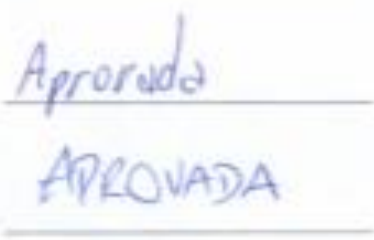


"Let us pick up our books and our pens. They are our most powerful weapons. One child, one teacher, one book and one pen can change the world."

(MALALA, 2014) 


\section{RESUMO}

VIEIRA, D. Obtenção e caracterização de biocompósitos formados a partir de hidroxiapatita sintética e fibroína de seda na forma de blocos para enxerto ósseo. 2018. 68 f. Dissertação (Mestrado) - Escola de Engenharia de São Carlos, Universidade de São Paulo, São Carlos, 2018.

Biomateriais que promovem e auxiliam a regeneração óssea vêm ganhando grande visibilidade em pesquisas na área de engenharia tecidual, em destaque os biocompósitos a partir de cerâmicas e polímeros. Muitos desafios abrangem essa área de pesquisa, sendo o principal, criar um material que mais se assemelha ao osso, não só em sua resistência mecânica, mas também em sua bioatividade e porosidade. Esse projeto tem como foco o desenvolvimento e processamento de blocos de biocompósito formados a partir de hidroxiapatita (HAp) e fibroína de seda (FS). A fibroína de seda, obtida a partir dos casulos do bicho-da-seda, foi lavada em solução de carbonato de sódio com concentração de $5 \%$ por 30 minutos. Sua dissolução foi realizada através de solução ternária contendo cloreto de cálcio, etanol e água, na proporção molar de 1:2:8. A HAp foi co-precipitada na FS dissolvida em solução ternária através de solução de fosfato $\left(\mathrm{Na}_{2} \mathrm{HPO}_{4}\right)$ sob agitação constante. Os blocos foram prensados manualmente e avaliou-se sua morfologia, relação $\mathrm{Ca} / \mathrm{P}$ e absorção de líquido definindo a melhor proporção de \%HAp e \%FS. Após a determinação da proporção $75 \%$ HAp e $25 \%$ FS, os blocos foram conformados em prensa hidráulica com pressões fixas de 50 e $100 \mathrm{MPa}$. As características morfológicas foram avaliadas através de análises de $\mathrm{MEV}$, porosidade, absorção de líquidos, microtomografia computadorizada ( $\mu$-CT) e medição da área superficial específica (BET). As características químicas e estruturais foram analisadas por EDS, FTIR, TGA e DRX. Além disso, avaliou-se a resistência à compressão, a bioatividade e a citotoxicidade do biocompósito. Os resultados mostram que o biocompósito estudado apresenta características químicas e estruturais próxima ao osso trabecular, resistência à compressão entre 2 e 10MPa e porosidade entre $30 \%$ e $70 \%$, é biocompatível e possui capacidade de formação de apatita. O biomaterial em estudo apresenta-se como uma boa perspectiva na área de engenharia tecidual óssea.

Palavras-chaves: Biocompósito, fibroína de seda, hidroxiapatita, regeneração óssea, engenharia de tecido. 


\begin{abstract}
VIEIRA, D. Obtainance and characterization of biocomposites prepared from synthetic hydroxyapatite and silk fibroin in form of blocks for bone grafting. 2018. $68 \mathrm{f}$. Dissertation (Master) - São Carlos School of Engineering, Ribeirão Preto Medical School and São Carlos Institute of Chemistry, University of São Paulo, São Carlos, 2018.
\end{abstract}

Biomaterials that promote and aid bone regeneration have gained great visibility in tissue engineering research, with emphasis on biocomposites from ceramics and polymers. Many challenges cover this area, the main is being to create a material similar to bone, not only in its mechanical strength but also in its bioactivity and porosity. This project focuses on the development and processing of biocomposite blocks formed by hydroxyapatite (HAp) and silk fibroin (SF). The silk fibroin, obtained from the cocoons of the silkworm, was washed in $5 \%$ sodium carbonate solution for 30 minutes. Its dissolution was carried out through a ternary solution containing calcium chloride, ethanol and water, in a molar ratio of 1: 2: 8. The HAp was co-precipitated in SF dissolved in ternary solution through phosphate solution $\left(\mathrm{Na}_{2} \mathrm{HPO}_{4}\right)$ under constant stirring. The blocks were manually pressed and their morphology, $\mathrm{Ca} / \mathrm{P}$ ratio and liquid absorption were evaluated to determine the best HAp/FS ratio. After defined the best ratio, $75 \% \mathrm{HAp}$ and $25 \% \mathrm{FS}$, blocks were formed in a hydraulic press with fixed pressures (50 and $100 \mathrm{MPa}$ ). The morphological characteristics were evaluated by SEM, Porosity, Liquid Absorption, Computerized Microtomography $(\mu-\mathrm{CT})$ and specific surface area (BET). The chemical and structural characteristics were analyzed by EDS, FTIR, TGA and XRD. In addition, the compressive strength, bioactivity and cytotoxicity of the composite were evaluated. The results show a biocomposite with chemical and structural characteristics close to the trabecular bone, mechanical resistance between 2 and $10 \mathrm{MPa}$ and porosity between $30 \%$ and $70 \%$, it is biocompatible and with apatite formation capacity. The biomaterial studied presents a good perspective in the field of bone tissue engineering.

Keywords: Biocomposite, silk fibroin, hydroxyapatite, bone regeneration, tissue engineering. 


\section{LISTA DE FIGURAS}

Figura 1 - (A) Crescimento do mercado de biomateriais (B) Distribuição do crescimento por aplicação 12

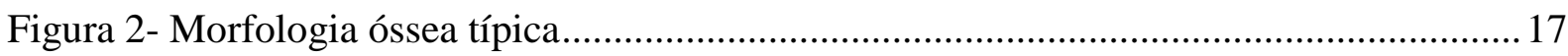

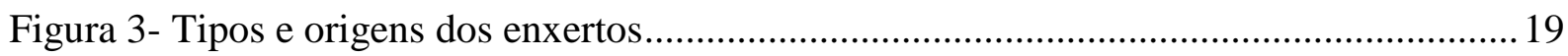

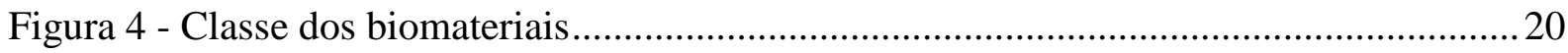

Figura 5 - (A) Seda: Origem e composição (B) Diferentes estruturas possíveis para fibroína

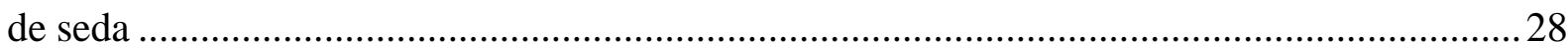

Figura 6 - Sequência de amino ácidos da cadeia de alta massa molecular da FS ...................29

Figura 7 - Esquema representativo da estrutura de folhas- $\beta$ presente na FS ..........................2 29

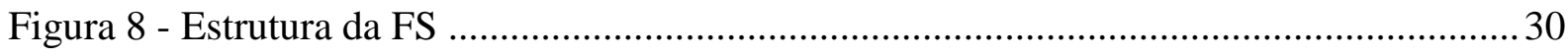

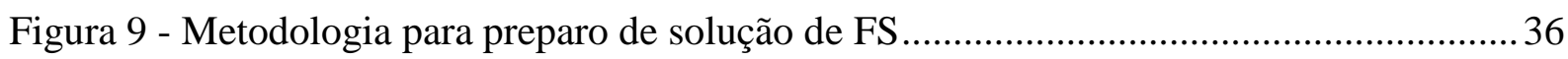

Figura 10 - Co-precipitação de HAp+ FS e preparação dos blocos ........................................ 37

Figura 11 - Fotomicrografias por MEV da amostra 75\%HAp25\%FS prensada manualmente 43

Figura 12 - Fotomicrografias do biocompósito prensado à 50MPa .......................................4 44

Figura 13 - Fotomicrografias do biocompósito prensado à 100MPa …................................. 45

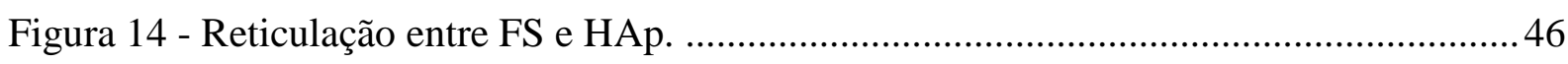

Figura 15 - Imagens de $\mu \mathrm{CT}$ das amostras prensadas à $50 \mathrm{MPa}$......................................... 48

Figura 16 - Imagens de $\mu \mathrm{CT}$ das amostras prensadas à $100 \mathrm{MPa}$........................................49

Figura 17 - Composição química do biocompósito (-) 75\%HAP + 25\% FS........................ 51

Figura 18 - Curva termogravimétrica (-) TGA (-) DTG (A) Biocompósito 75\%HAp/25\%FS (B) Fibroína de seda

Figura 19 - Espectroscopia de absorção no infravermelho de: A (一) biocompósito 75\%HAp/25\%FS; B (一) Fibroína de seda; C (-) HAP de fêmur bovino desproteinizado...55 Figura 20 - Difração de Raio-X padrão (-) biocompósito 75\%HAp/25\%FS.........................56

Figura 21 - Resistência à compressão mecânica do biocompósito 75\%HAP + 25\%FS ..........58

Figura 22 - Evidências de presença do defeito de laminação nas amostras prensadas ............59 Figura 23 - Fotomicrografias das amostras em ensaio SBF (A) 0 dias (B) 14 dias (C) 28 dias

Figura 24 - Esquema representativo da formação de apatita sob a camada de hidroxiapatita .62 Figura 25 - Curvas de viabilidade celular: (-) Controle positivo (-) Controle negativo (-) $75 \% \mathrm{HAp}+25 \% \mathrm{FS}$ prensado $50 \mathrm{MPa}(-)$ 75\%HAp+25\%FS prensado $100 \mathrm{MPa}$ .63 


\section{LISTA DE TABELAS}

Tabela 1 - Comparativo das propriedades dos enxertos autógenos e alógenos ......................... 18

Tabela 2 - Tamanhos de poros e a etapa de crescimento ósseo.............................................. 21

Tabela 3 - Fatores importantes na seleção dos materiais para aplicação biomédica ................22

Tabela 4- Propriedades dos ossos e das principais cerâmicas bioativas e suas aplicações. ..... 23

Tabela 5 - Principais técnicas e características da HAp final................................................26

Tabela 6 - Características mecânicas FS e demais fibras poliméricas .....................................31

Tabela 7 - Relação Ca/P, absorção de álcool e resistência à compressão para as amostras prensadas manualmente

Tabela 8 - Porosidade e absorção de líquido do composto 75\%HAP + 25\%FS prensados a 50

e $100 \mathrm{MPa}$ 47

Tabela 9 - Resultados obtidos pela análise CTAN 49

Tabela 10 - \% dos elementos químicos presentes no biocompósito experimental e na hidroxiapatita teórica 


\section{SUMÁRIO}

1. INTRODUÇÃO ....................................................................................................................12

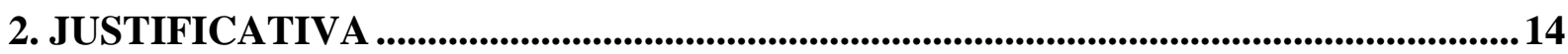

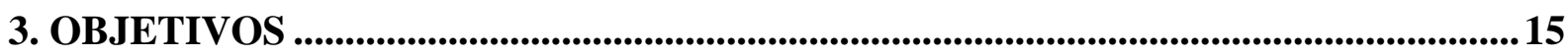

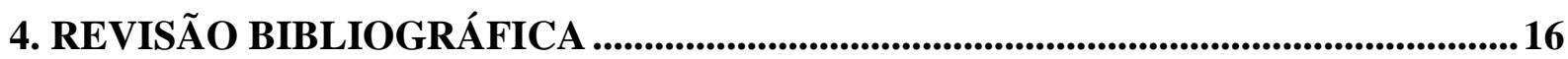

4.1 Sistema ósseo e sua morfologia..................................................................................................16

4.2 Engenharia de tecido ósseo .........................................................................................................17

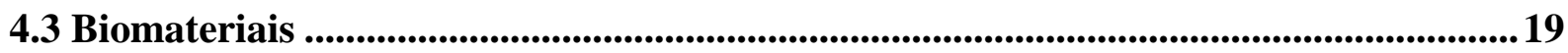

4.4 Biocerâmicas ...................................................................................................................................22

4.5 Biopolímeros ..............................................................................................................26

4.6 Biocompósitos ................................................................................................................................31

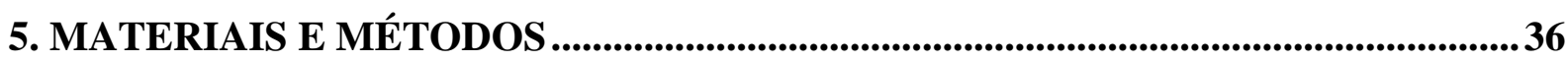

5.1 Obtenção, Purificação e Solubilização da Fibroína de Seda ..............................................36

5.2 Obtenção do biocompósito .....................................................................................................36

5.3 Caracterizações dos biocompósitos obtidos .........................................................................38

5.3.1 MICROSCOPIA ELETRÔNICA DE VARREDURA (MEV) …………………............. 38

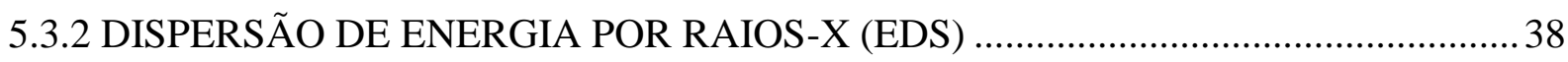

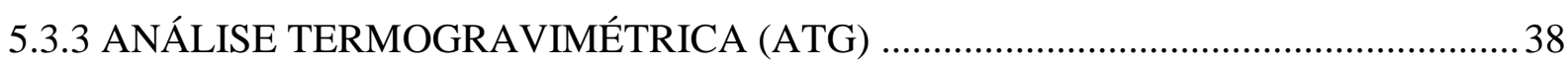

5.3.4 ESPECTROSCOPIA NO INFRAVERMELHO POR TRANSFORMADA DE

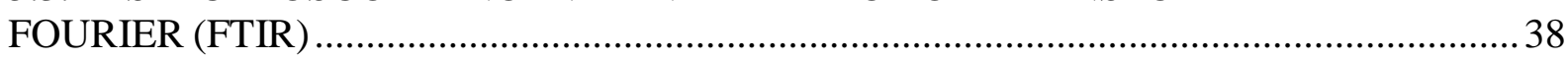

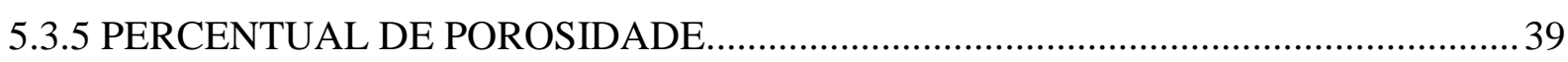

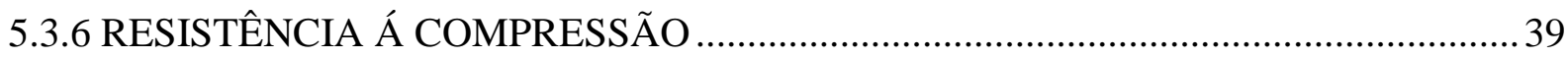

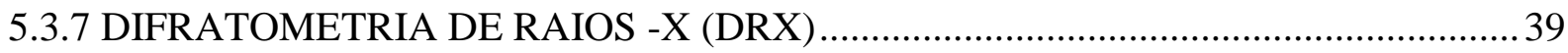

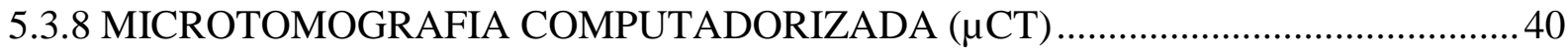

5.3.9 ÁREA SUPERFICIAL ESPECÍFICA (BET) …………............................................ 40

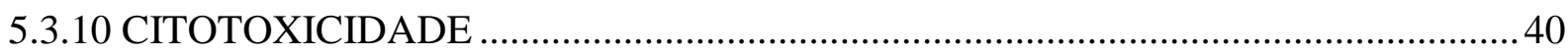

5.3.11 AVALIAÇÃO IN VITRO DA CAPACIDADE DE FORMAÇÃO DE APATITA .....40

6. RESULTADOS E DISCUSSÕES...............................................................................42

6.1 Definição da relação orgânica/inorgânica do biocompósito ...............................................42

6.2 Microscopia eletrônica de varredura (MEV) ..................................................................... 43

6.3 Porosidade e absorção de líquidos ...........................................................................................46

6.4 Microtomografia computadorizada $(\mu-\mathrm{CT})$..................................................................... 48

6.5 Área superficial (BET) .............................................................................................50

6.6 Análise da relação Ca/P (EDS) ............................................................................................51 


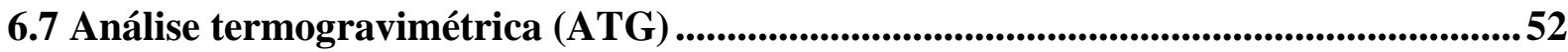

6.8 Espectroscopia na região do infravermelho (FTIR)................................................54

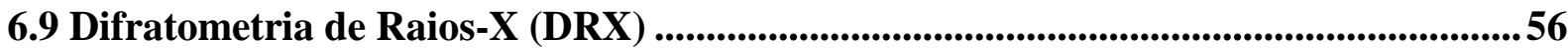

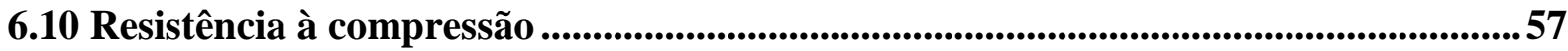

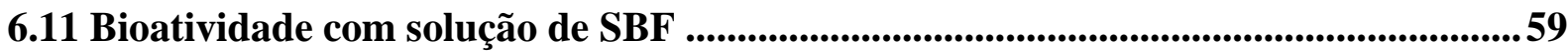

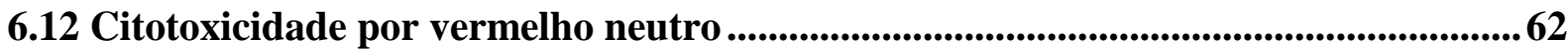

7. CONCLUSÃO

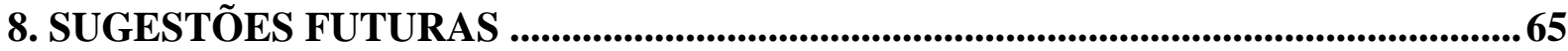

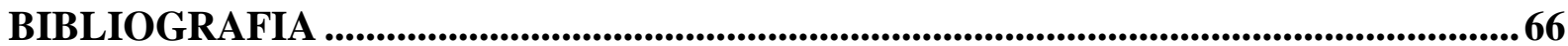




\section{INTRODUÇÃO}

A engenharia tecidual vem se apresentando como uma estratégia promissora para a área de regeneração óssea. Estima-se que em 2020, no mundo todo, aproximadamente 6,6 milhões de cirurgias ortopédicas serão realizadas anualmente para reparo de defeitos ósseos provenientes de fraturas, doenças ou má formação. Nos Estados Unidos, 1,3 milhões de pessoas se submetem a cirurgias do sistema ósseo anualmente. Nesse contexto, faz-se necessário desenvolver substitutos biológicos que imitam a estrutura e a função dos tecidos originais (MANDAL et al., 2012; MCNAMARA et al., 2014; MELKE et al., 2016).

O mercado de biomateriais para tratamentos ortopédicos cresce a uma taxa veloz (Figura 1). O foco atual está em materiais bioativos, ou seja, que interajam com moléculas biológicas e células, e, regenerem os tecidos. Para a integração com o sistema ósseo também é desejado que esses apresentem osteoindução, osteocondução e osteointegração. Além disso, espera-se boa resistência mecânica, biocompatibilidade e biodegradabilidade, o que irá permitir a reposição do biomaterial enxertado por novo tecido ósseo (STEVENS et al., 2008; LIN et al., 2012; MCNAMARA et al., 2014).

Figura 1 - (A) Crescimento do mercado de biomateriais (B) Distribuição do crescimento por aplicação

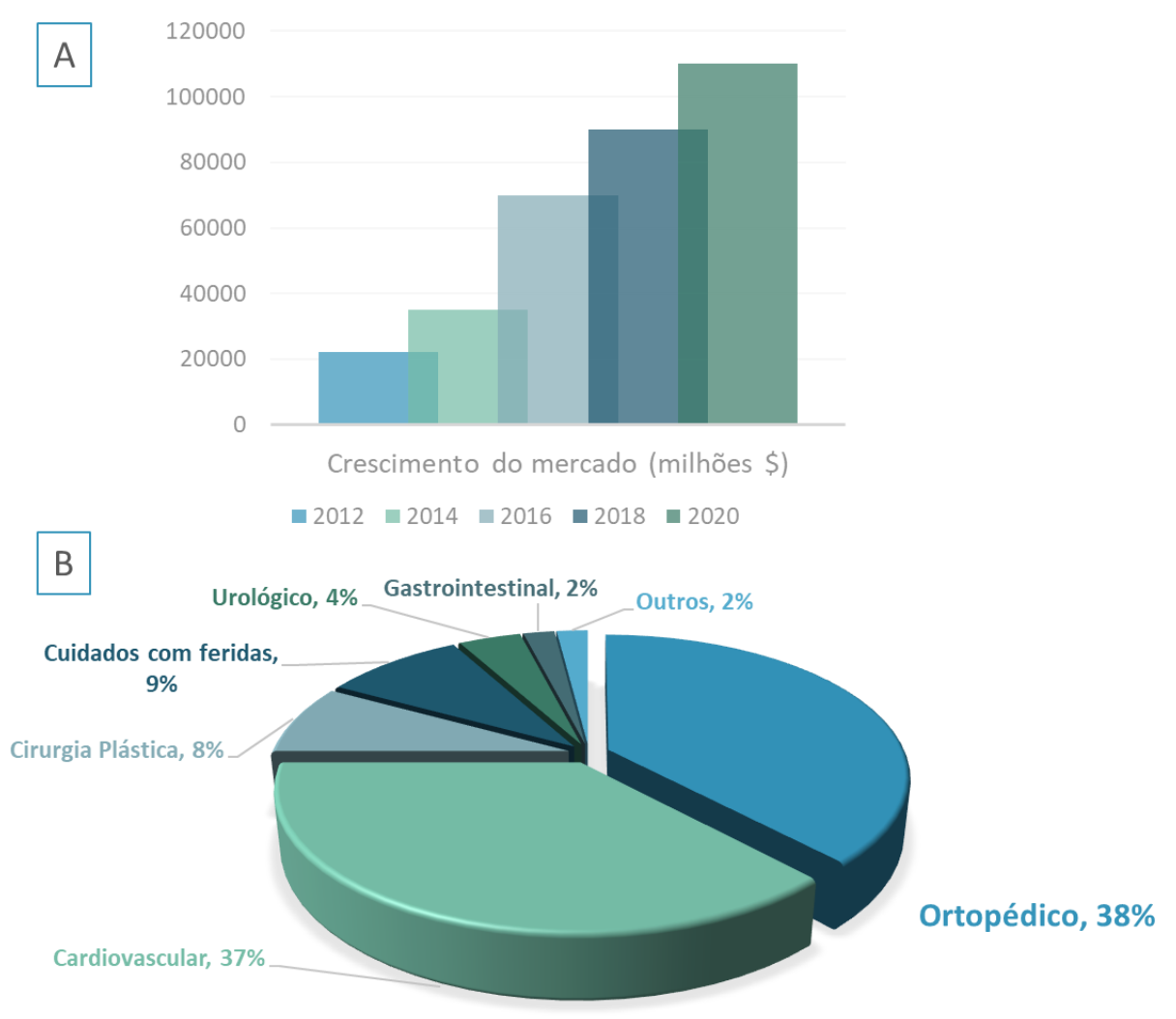

Fonte: Adaptado de Bajaj (2018) 
As biocerâmicas com alta porosidade têm atraído à atenção de pesquisadores como um substituo ósseo, pois, a mesmas apresentam estrutura porosa tridimensional que proporciona condições ideias para o crescimento de células. A porosidade permite permeabilidade, difusão de oxigênio e nutrientes e criação de integração vascular. Porém, as cerâmicas são naturalmente frágeis tornando-as não apropriadas para suportar cargas sozinhas. A junção de dois materiais diferentes para formar um biocompósito tem como objetivo mimetizar o tecido, ou seja, aproximar o mais real possível da composição óssea, permitindo aumento da resistência mecânica e aumento do potencial de osteoindução (LIN et al., 2012; MCNAMARA et al., 2014; MELKE et al., 2016).

As propriedades mecânicas dos biocompósitos podem ser incrementadas com o uso de polímeros naturais tais como, colágeno, quitosana e fibroína de seda. Esta, vem se destacando por possuir propriedades biomédicas e mecânicas relevantes, além de propriedades térmicas excelentes (temperatura de desnaturação acima de $150^{\circ} \mathrm{C}$ ). Diversas linhas de pesquisa ao redor do mundo estão estudando um novo tipo de suporte para reparo ósseo a partir desse biopolímeros (JUDAS et al., 2012).

Apesar de suas características favoráveis, a fibroína de seda, se utilizada sozinha, apresenta pontos de atenção para uso em aplicações clínicas e processos industriais, tais como, baixa rigidez (alta maleabilidade) e alto custo de produção. Por essas razões, diversos estudos, envolvendo a fibroína de seda, vêm sendo realizados para aumentar as propriedades das mesmas. Sendo então uma área de rápido crescimento dentro das pesquisas em engenharia de tecido (JIANG et al., 2013). 


\section{JUSTIFICATIVA}

O maior desafio hoje nas pesquisas para enxertos ósseos é encontrar um biomaterial que se pareça o mais próximo possível do osso, com sua estrutura de poros (teor, distribuição de tamanhos, formato e interconectividade) e com as propriedades mecânicas semelhantes. O uso de suportes possibilita alta porosidade, permitindo a formação tridimensional de um novo tecido. Eles permitem a formação de um microambiente, onde ocorrerá proliferação controlada das células, diferenciação das mesmas e a criação de uma população celular ao seu redor, sendo que esses fatores são essenciais para o processo de reparação (STEVENS et al., 2008; LIN et al., 2012; BICALHO et al., 2011).

Pesquisas recentes com diferentes biopolímeros demonstram que ainda existem muitos campos a serem explorados dentro da engenharia de tecidos. Suportes à base de colágeno, por exemplo, não apresentam as propriedades mecânicas desejadas. Outro polímero utilizado em suportes é o poli(caprolactona), porém, apesar de ser biocompatível e possuir taxa lenta de degradação, não apresenta resposta óssea sem pré-mineralização. Nesse contexto, os suportes baseados em fibroína de seda têm demonstrado ótimas habilidades para auxiliar na regeneração de tecidos ósseos, porém, devido à estrutura tridimensional e a porosidade ainda não ideal, não apresentam as propriedades mecânicas desejadas (GIL et al., 2011).

O projeto visou o processamento do biocompósito de hidroxiapatita e a fibroína de seda em forma de blocos não sinterizados, focando em obter a relação porosidade versus resistência à compressão ideal. Atualmente existem diversas pesquisas envolvendo biocompósitos de hidroxiapatita e a fibroína de seda em diferentes formatos, tais como gel, esponjas, entre outros, porém, com a utilização de técnicas de processamento caras e demoradas. A inovação do biocompósito de hidroxiapatita com fibroína de seda, no formato de blocos não sinterizados e apenas prensados, permitirá uma redução significativa de custos no processo de produção e características relevantes para o uso como enxerto ósseo na engenharia de tecidos. 


\section{OBJETIVOS}

- Geral

Este trabalho teve como objetivo desenvolver biocompósitos de hidroxiapatita com fibroína de seda sem o processo de sinterização e caracterizá-los para o uso na engenharia de tecido ósseo.

- Específicos

- Extrair e solubilizar a fibroína de seda;

- Desenvolver blocos de biocompósito de hidroxiapatita com fibroína de seda através do processo de prensagem;

- Caracterizar blocos de biocompósito quanto à morfologia, estrutura, porosidade, composição, comportamento termodinâmico e resistência à compressão;

- Realizar testes preliminares de citotoxicidade in vitro nos blocos; 


\section{REVISÃO BIBLIOGRÁFICA}

\subsection{Sistema ósseo e sua morfologia}

O sistema ósseo humano é formado por 206 ossos, dos quais, 126 pertencem ao esqueleto apendicular (membros superiores e inferiores), 74 ao axial (cabeça, pescoço e tronco) e 6 ossículos auditivos. Os ossos possuem capacidade de se modelarem durante toda a vida, auxiliando na adaptação às mudanças dos esforços biomecânicos e na regeneração de tecido antigo ou com pequenas danificações, dessa maneira, se mantém mecanicamente mais forte (BILEZIKIAN et al., 2002; CLARKE, 2008).

Os ossos estão classificados em quatro categorias: longos, incluindo as clavículas, úmero, rádio, ulna, metacarpos, fêmur, tíbias, fíbulas, metatarsos e falanges; curtos, encontrados no carpo e tarso e sesamóides; planos, sendo o crânio, a mandíbula, a escápula, o esterno e as costelas; e por último, os irregulares onde estão as vértebras, o sacro, o cóccix e o hioide (BILEZIKIAN et al., 2002; CLARKE, 2008).

O esqueleto possui uma variedade de funções, dentre elas, fornece estrutura para todo o corpo, permite o movimento e a locomoção, fornece suportes para os músculos, protege os órgãos e estruturas internas vitais, proporciona manutenção da homeostase mineral e do equilíbrio ácido-base, e ainda, proporciona o meio para a formação, desenvolvimento e maturação dos elementos sanguíneos no interior da medula. O osso possui duas formações, sendo elas: cortical, com morfologia densa e sólida; e trabecular formado por uma rede de placas de trabéculas (BILEZIKIAN et al., 2002; CLARKE, 2008; STEVENS et al., 2008). Ele é composto por uma matriz orgânica (20 a 40\%) e mineral (50 a 70\%), além de água (5 a $10 \%)$ e lipídeos $(3 \% \mathrm{~g} / \mathrm{g})$. O principal constituinte da fase mineral é a hidroxiapatita (HAp, $\left.\mathrm{Ca}_{10}(\mathrm{OH})_{2}\left(\mathrm{PO}_{4}\right)_{6}\right)$. É possível observar na Figura 2 a morfologia óssea típica.

O colágeno tipo I constitui aproximadamente $95 \%$ da matriz orgânica, sendo que, os 5\% restantes são demais proteínas. A porção cerâmica proporciona resistência à compressão, enquanto que a orgânica permite sua elasticidade e flexibilidade (PRECHEUR, 2007; CLARKE, 2008; PRAKASAM et al., 2015; ORYAN; ALIDADI, 2017). A estrutura porosa é formada por diferentes tamanhos de poros e com porosidade entre 30 e $90 \%$, dependendo da carga exercida, da idade e do estado de saúde óssea. Quando há perda do tecido, por doenças ou traumas, é utilizado o enxerto ósseo, sendo esse escolhido com base nas propriedades biomecânicas necessárias, composição química, densidade e tamanho do local do defeito. (BILEZIKIAN et al., 2002; CLARKE, 2008; PRAKASAM et al., 2015) 
Figura 2- Morfologia óssea típica

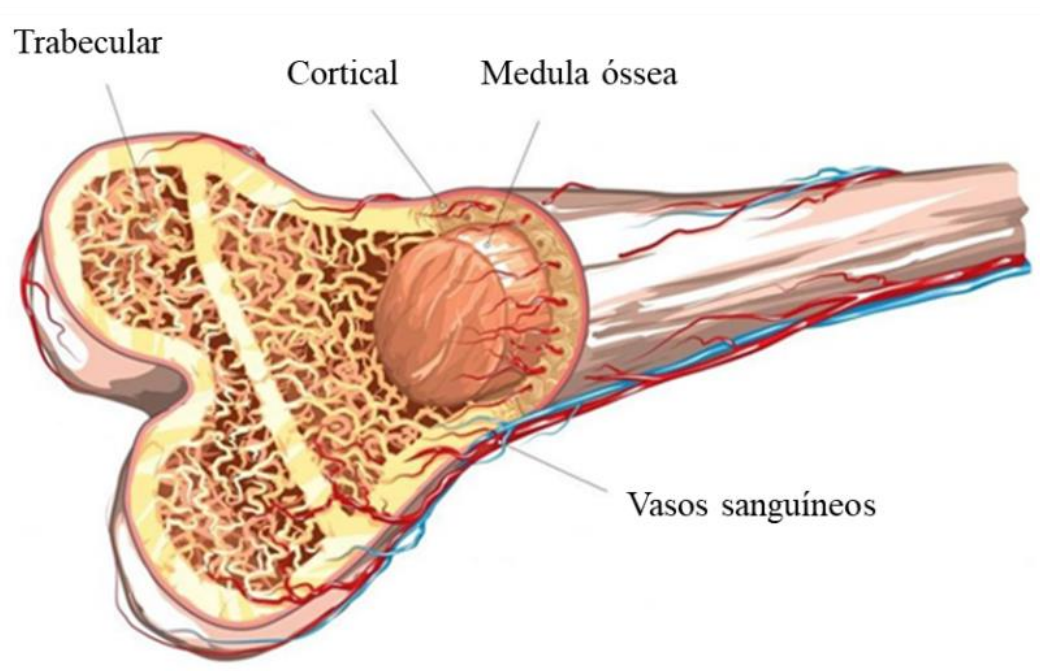

Fonte: adaptado de Dalton (2017)

\subsection{Engenharia de tecido ósseo}

Nas últimas décadas a demanda por substitutos sintéticos cresceu em um ritmo acelerado devido ao aumento do número de traumas causados por acidentes e defeitos inerentes à doenças e envelhecimento da população. As maiores demandas são para a área craniana, dental, maxi facial, ortopédicas e de coluna. As recentes melhorias nos materiais, na bioengenharia e nas técnicas de enxertos, têm auxiliado grandemente muitos pacientes ao redor do mundo. As constantes inovações com células troncos, biomateriais e órgãos artificiais demostram uma enorme evolução na ciência biomédica. (PRAKASAM et al., 2015)

Existem três principais características desejadas em um biomaterial substituto, sendo elas: osteogênese, osteoindução e osteocondução. A osteogênese é um processo em que o material implantado auxilia na formação de um novo tecido por meio de células já existentes e maduras. A osteoindução é a capacidade de induzir a formação de tecido através da diferenciação de células imaturas (mesenquimais). Por fim, a osteocondução é a formação de osso ao longo da superfície do suporte (GREENWALD et al., 2001; KAO, SCOTT, 2007).

Os enxertos autógenos são provindos do mesmo indivíduo, sendo alocados de uma região para outra. Esses são considerados como padrão de referência quando comparados com os demais tipos porque eles possuem osteogênese, osteoindução e osteocondução. Como pertencem ao mesmo ser humano, apresentam baixíssimo risco de rejeição, porém como desvantagem, possuem a limitação do material e a morbidade associada com a coleta desses. (GREENWALD et al., 2001; PRECHEUR, 2007; STEVENS, 2008; ORYAN; ALIDADI, 
Os enxertos alógenos são adquiridos de seres da mesma espécie, porém, geneticamente diferentes (muitas vezes são provindos de cadáveres). Uma vez coletado, o material deve passar por um tratamento para eliminar os componentes contaminantes e reduzir a reposta imune do hospedeiro, porém, esses processos enfraquecem as propriedades mecânicas dos enxertos e sua estrutura. (GREENWALD et al., 2001; KAO, SCOTT, 2007; PRECHEUR, 2007). Na tabela 1 é possível observar a comparação das estruturas de enxertos autógenos e alógenos em relação às características almejadas.

Tabela 1 - Comparativo das propriedades dos enxertos autógenos e alógenos

\begin{tabular}{c|c|c|c|c}
\hline Enxerto & $\begin{array}{c}\text { Resistência } \\
\text { Mecânica }\end{array}$ & Osteocondução & Osteoindução & Osteogênese \\
Autógeno trabecular & Não & +++ & +++ & ++ \\
Alógeno trabecular & Não & ++ & + & Não \\
\hline
\end{tabular}

Fonte: Adaptado de Greenwald et al. (2001)

Os xenógenos, derivados de espécies diferentes do hospedeiro (sendo os mais utilizados provenientes do osso bovino), possuem alta porosidade, por volta de $75 \%$, os que os tornam um material com boa osteocondução. Porém, devido aos macroporos naturais, a estabilidade inicial quando enxertado é comprometida. Sua grande área superficial aumenta a angiogênese e é de grande auxilio no crescimento ósseo. (KAO, SCOTT, 2007; PRECHEUR, 2007)

O material ideal para exercer tal função deve ser biocompatível, bioreabsorvível, osteocondutivo, osteoindutivo, permitir o crescimento do novo tecido através dele, apresentar estrutura mecânica similar ao osso que irá substituir, fácil de aplicar e armazenar e, ainda, apresentar ótimo custo benefício. Diversos biomateriais estão disponíveis no mercado, tais como, os biovidros, óxido de alumínio (alumina), sulfato de cálcio, fosfatos de cálcio e hidroxiapatita sintética. (KAO, SCOTT, 2007; PRECHEUR, 2007) Na Figura 3 está esquematizado os tipos e origens dos enxertos ósseos. 


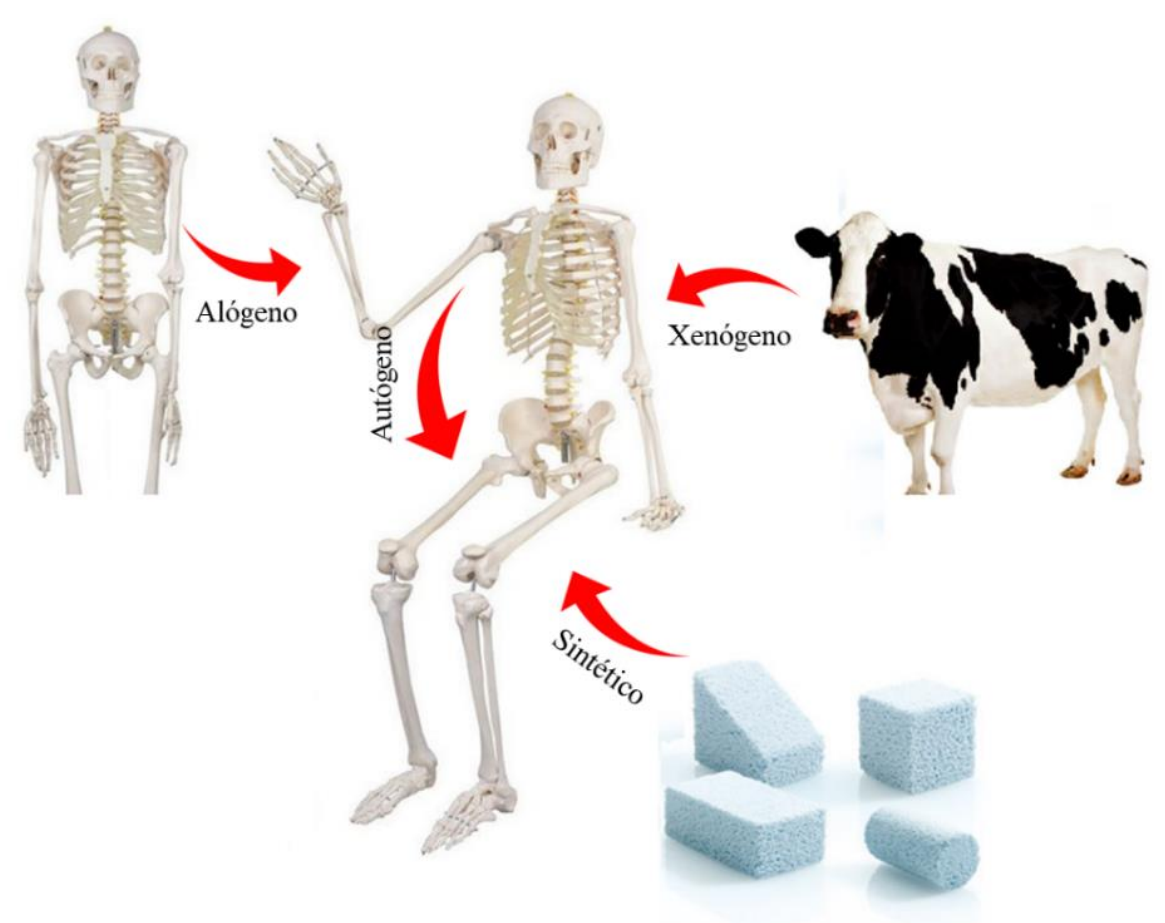

Fonte: Elaborado pela autora

\subsection{Biomateriais}

A ciência dos biomateriais envolve o estudo físico e químico de materiais que têm como foco a interação com o meio biológico. Tradicionalmente são estudadas as sínteses, caracterizações e a biologia desses materiais que serão utilizados em tecidos hospedeiros. Uma das principais características exigida é a biocompatibilidade, ou seja, suportar as células, a função e não provocar reação imune ou resposta inflamatória (RATNER et al., 2012; AHADIAN et al., 2017). De acordo com Ratner et al. (2012), a biocompatibilidade tem que ser definida de acordo com a aplicação desejada e não é uma propriedade comum ao mesmo material, por exemplo, existem biomateriais que são hemocompatíveis, porém não são osteocompatíveis.

Os biomateriais são classificados em dois grupos: naturais e sintéticos. Os naturais são encontrados nos tecidos, como colágeno e fibrina, eles têm sido utilizados em implantes há muitos anos. Essa classe apresenta benefícios quando comparadas com os sintéticos, tais como, biodegradabilidade, propriedades biológicas e boa e interação celular, porém, como desvantagens, eles podem causar resposta imune devido às interações celulares, baixas propriedades mecânicas, desestabilidade e baixa reprodutibilidade (RATNER et al., 2012; 
AHADIAN et al., 2017).

Já os sintéticos, como metais, cerâmicas e polímeros, podem ser reproduzidos em grandes escalas, são fáceis de esterilizar e exibem melhorias nas propriedades mecânicas e químicas, porém, não apresentam alta interação celular e podem gerar respostas inflamatórias após o implante. Na Figura 4 observa-se essa classificação e suas possíveis aplicações na engenharia de tecidos (RATNER et al., 2012; AHADIAN et al., 2017).

\section{Figura 4 - Classe dos biomateriais}

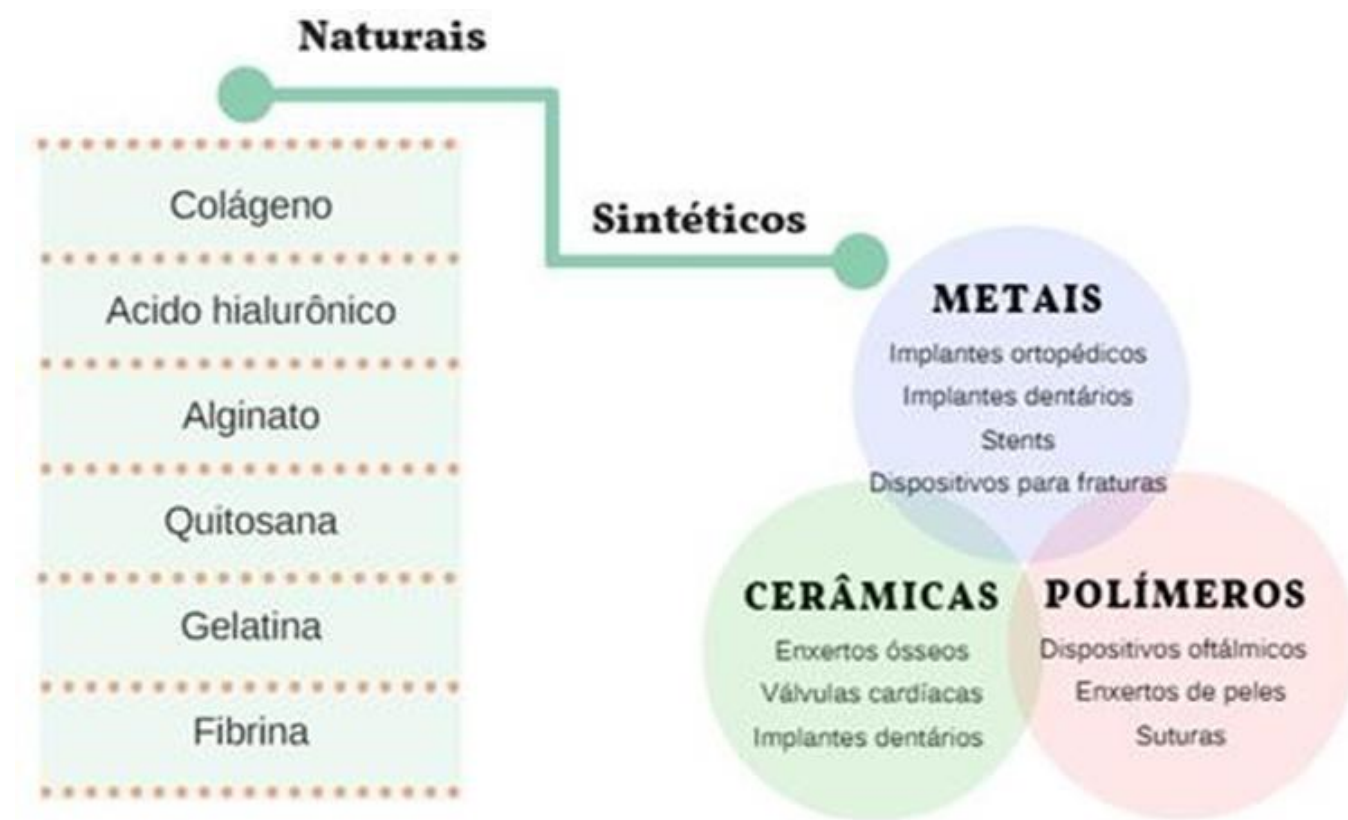

Fonte: Adaptado de Ahadian et al. (2017)

No geral, esses biomateriais devem apresentar também biodegradabilidade, propriedades específicas de superfície, porosidade e resistência mecânica. As propriedades mecânicas são parâmetros de grande importância para a engenharia de tecido, pois, o implante deve desenvolver e manter um ambiente adequado para o crescimento e funcionalização do novo tecido (RATNER et al., 2012; AHADIAN et al., 2017).

A porosidade é um fator essencial para o desenvolvimento de biomateriais para a regeneração óssea. Além de auxiliar na fixação e permitir a ligação química com o osso, os poros abertos e conectados estão diretamente ligados à formação óssea e, são essenciais para a adesão e crescimento celular. A interconexão ainda permite a disponibilidade de um caminho para o crescimento de vasos sanguíneos, essenciais para a nutrição do novo tecido formado. (PRAKASAM et al., 2015; SIERRA et al., 2017).

O tamanho dos poros é uma característica relevante nos scaffolds. O novo tecido e sua 
conexão com o material é dependente do tamanho ideal dos orifícios, que devem variar de acordo com cada etapa necessária para o crescimento do osso. Na Tabela 2 estão listados os tamanhos de poros ideais para cada etapa de crescimento ósseo. Um modelo 3D cerâmico ideal deve promover um ambiente propício aos constituintes celulares e extracelulares possuindo porosidade de diferentes tamanhos (KLAWITTER, HULBERT, 1971; KOMLEV, BARINOV, 2002; SIERRA et al., 2017)

Tabela 2 - Tamanhos de poros e a etapa de crescimento ósseo

\begin{tabular}{c|c}
\hline Etapas & Tamanho de poro necessário \\
Osteócitos & $100-500 \mathrm{~nm}$ \\
Osteoclastos & $10-20 \mu \mathrm{m}$ \\
Vascularização & $5-125 \mu \mathrm{m}$ \\
Crescimento de tecido & $100-350 \mu \mathrm{m}$ \\
\hline
\end{tabular}

Fonte: Komlev, Barinov (2002)

A escolha do biomaterial para a correta aplicação é um processo complexo e de muito estudo, lembrando que a interação entre esse e o tecido hospedeiro é extremamente relevante. Esses devem mimetizar a função da matriz extracelular substituída, incluindo sua interação celular e tecidual, assim, deve-se selecionar de acordo com as propriedades mecânicas, físicas, químicas e biológicas exigidas. Na Tabela 3 tem-se um guia geral para os fatores a serem observados durante a escolha do biomaterial. (AHADIAN et al., 2017). 
Tabela 3 - Fatores importantes na seleção dos materiais para aplicação biomédica

\begin{tabular}{|c|c|c|c|}
\hline Fatores a observar & \multicolumn{3}{|c|}{ Descrição } \\
\hline Primeiro: Funções gerais & $\begin{array}{l}\text { Composição química } \\
\text { (interior e superfície) }\end{array}$ & Densidade & $\begin{array}{l}\text { Módulo de elasticidade, } \\
\text { resistência à compressão } \\
\text { e à tração }\end{array}$ \\
\hline Segundo: Funções gerais & Adesão química & $\begin{array}{l}\text { Topologia da superfície } \\
\text { (Textura e rugosidade) }\end{array}$ & $\begin{array}{c}\text { Dureza, resistência ao } \\
\text { cisalhamento, resistência } \\
\text { à flexão }\end{array}$ \\
\hline $\begin{array}{l}\text { Terceiro: Funções } \\
\text { específicas baseadas na } \\
\text { aplicação }\end{array}$ & $\begin{array}{l}\text { Biofuncionalidade, } \\
\text { bioinerte, bioatividade, } \\
\text { bioestabilidade e } \\
\text { biodegradação }\end{array}$ & $\begin{array}{c}\text { Forma, geometria, } \\
\text { condutividade térmica e } \\
\text { elétrica, cor, opacidade e } \\
\text { transparência }\end{array}$ & $\begin{array}{l}\text { Rigidez, maciez, } \\
\text { resistência à fadiga, ao } \\
\text { impacto, à adesão e à } \\
\text { abrasão }\end{array}$ \\
\hline $\begin{array}{l}\text { Quarto: Processo e } \\
\text { fabricação }\end{array}$ & \multicolumn{3}{|c|}{ Reprodutibilidade, qualidade, esterilização, embalagem, armazenamento e custo } \\
\hline $\begin{array}{l}\text { Quinto: Características do } \\
\text { hospedeiro }\end{array}$ & \multicolumn{3}{|c|}{$\begin{array}{l}\text { Tecido, órgão, espécie, idade, sexo, condições de saúde, atividade, resposta } \\
\text { sistêmica e procedimento utilizado }\end{array}$} \\
\hline
\end{tabular}

Fonte: Adaptado de Ramakrishna et al. (2001)

\subsection{Biocerâmicas}

O uso de biocerâmicas para aplicações médicas tem predominado há alguns anos, essas incluem alumina $\left(\mathrm{Al}_{2} \mathrm{O}_{3}\right)$, zircônia $\left(\mathrm{ZrO}_{2}\right)$, hidroxiapatita e demais fosfatos de cálcio reabsorvíveis. Apresentam como características principais a não-toxicidade, estabilidade química em meio biológico e biocompatibilidade. São classificadas como bioinertes, bioreabsorvíveis e bioativas. (PRAKASAM et al., 2015; IBRAHIM et al., 2017; ORYAN; ALIDADI, 2017)

As cerâmicas bioinertes não interagem com o meio hospedeiro, formando tecidos fibrosos na interface dos materiais implantados. As bioreabsorvíveis permitem que o tecido hospedeiro substitua o material implantado, pois são degradadas pelo corpo humano. Já as bioativas, como o bioglass (biovidro) e a hidroxiapatita, são capazes de se ligar com os tecidos e induzir seus crescimentos, possuindo alto potencial nas aplicações biomédicas devido à resistência à corrosão e ao desgaste. As bioativas possuem a capacidade de formação 
de uma camada de apatita em sua superfície quando implantada, mediando a integração com a matriz óssea (KOKUBO; KIM; KAWASHITA, 2003; IBRAHIM et al., 2017; ORYAN; ALIDADI, 2017).

Apesar das fragilidades das cerâmicas, as demais propriedades permitem uma grande área de aplicação, tais como, restaurações dentárias, implantes na orelha e coluna vertebral, substituições de ossos faciais e cranianos e preenchimento de defeitos ósseos no geral. Dentre as biocerâmicas, a hidroxiapatita se destaca por possuir diversas formas e permitir sua aplicação em diferentes áreas, além de excelente capacidade de integração óssea. Na Tabela 4 é possível observar as propriedades das principais cerâmicas bioativas e dos ossos (PRAKASAM et al., 2015; ORYAN; ALIDADI, 2017).

Tabela 4- Propriedades dos ossos e das principais cerâmicas bioativas e suas aplicações.

\begin{tabular}{|c|c|c|c|}
\hline Material & $\begin{array}{c}\text { Resistência à } \\
\text { compressão (MPa) }\end{array}$ & $\begin{array}{c}\text { Tempo de } \\
\text { degradação (meses) }\end{array}$ & $\begin{array}{c}\text { Aplicação na engenharia de } \\
\text { tecido ósseo }\end{array}$ \\
\hline Osso cortical & $131-224$ & $\begin{array}{l}\text { Regeneração óssea } \\
\text { natural }\end{array}$ & Enxertos autógenos e alógenos \\
\hline Osso trabecular & $2-10$ & $\begin{array}{c}\text { Regeneração óssea } \\
\text { natural }\end{array}$ & Enxertos autógenos e alógenos \\
\hline $\begin{array}{c}\text { Hidroxiapatita } \\
{\left[\mathrm{Ca}_{10}\left(\mathrm{PO}_{4}\right)_{6}(\mathrm{OH})_{2}\right]}\end{array}$ & $500-1000$ & $>24$ & $\begin{array}{c}\text { Scaffolds, preenchimento, liberação } \\
\text { de drogas, recobrimentos }\end{array}$ \\
\hline $\begin{array}{l}\text { Fosfato tricálcico } \\
\qquad\left[\mathrm{Ca}_{3}\left(\mathrm{PO}_{4}\right)_{2}\right]\end{array}$ & 154 & $>24$ & $\begin{array}{l}\text { Preenchimento (grânulos, pastas e } \\
\text { cementos) }\end{array}$ \\
\hline $\begin{array}{c}\text { Brushita } \\
{\left[\mathrm{CaHPO}_{4} \cdot 2 \mathrm{H}_{2} \mathrm{O}\right]}\end{array}$ & $35-60$ & $>24$ & Liberação de drogas e restauração \\
\hline Monetita $\left[\mathrm{CaHPO}_{4}\right]$ & $15-25$ & $3-6$ & $\begin{array}{l}\text { Parafusos, preenchimento de } \\
\text { defeitos }\end{array}$ \\
\hline Bioglass & $40-60$ & Não degrada & $\begin{array}{l}\text { Preenchimento de } \\
\text { defeitos }\end{array}$ \\
\hline
\end{tabular}




\section{Scaffolds de Fosfatos de Cálcio}

Ao longo das últimas décadas, a engenharia de tecidos foi considerada uma solução alternativa para o reparo e regeneração de tecido humano danificado. Particularmente, no caso da área óssea, os scaffolds (suportes) atuam como a matriz que apoia a formação de novo material biológico. Esses devem possuir alguns requisitos básicos, como porosidade elevada, poros com tamanhos específicos, propriedades de superfície que permitem a adesão, a diferenciação e a proliferação celular, além de possuir integridade mecânica e biocompatibilidade (SABIR; XU; LI, 2009; PRAKASAM et al., 2015).

Os suportes de fosfato de cálcio $(\mathrm{CaP})$ são considerados como um material interessante, pois são bioativos e auxiliam na adesão e proliferação celular, apesar de possuírem baixas resistências mecânicas. No geral, as biocerâmicas de CaP são caracterizadas pela composição química (estequiometria e pureza), homogeneidade, distribuição da fase, tamanho e forma do grão, cristalinidade, tamanho de poros e distribuição da porosidade (PRAKASAM et al., 2015; ORYAN; ALIDADI, 2017).

A grande maioria dos fosfatos de cálcio são baseadas em hidroxiapatita (HAp), fosfato $\beta$-tricálcico $(\beta$-TCP), fosfato $\alpha$-tricálcico $(\alpha-\mathrm{TCP})$ ou fosfato de cálcio bifásico (BCP) (que é uma mistura de $\beta$-TCP + HAp ou $\alpha$-TCP + HAp). As biocerâmicas de CaP produzidas em temperatura ambiente possuem duas propriedades diferentes quando comparadas com as sinterizadas, sendo, a área de superfície especifica mais próxima a do osso e a formação de fases percursoras de apatita óssea (ORYAN; ALIDADI, 2017).

\section{Hidroxiapatita}

A Hidroxiapatita (HAp) é um biomaterial amplamente explorado para aplicações médicas, sendo um fosfato de cálcio estável sob condições fisiológicas. Além da sua bioatividade, a sua estrutura química é semelhante ao componente mineral dos ossos e outros tecidos rígidos, como dentes e cartilagem mineralizada. Suas características fazem com que HAp possa ser aplicada em diferentes áreas médicas, tais como matrizes para a liberação controlada de fármacos e na engenharia de tecido ósseo (além de sua biocompatibilidade com tecidos duros, também é usada para o reparo do tecido mole) (SHOJAI et al., 2013; PRAKASAM et al., 2015; IBRAHIM et al., 2017; HAIDER et al., 2017).

A HAp é mais comumente usada na regeneração óssea como substitutos, preenchimentos, e em revestimentos para implantes metálicos. Apresenta relação estequiométrica entre Cálcio/Fósforo $(\mathrm{Ca} / \mathrm{P})$ igual ao valor de 1,67. HAp sintética possui uma 
ampla gama de aplicações biomédicas sob a forma de pós, micro- ou nanocristais, blocos, folhas, cerâmicas densas ou porosas e filmes finos, podendo ser utilizada pura ou em compósitos (SHOJAI, et al., 2013; ORYAN; ALIDADI, 2017; HAIDER et al., 2017).

A hidroxiapatita degrada no corpo humano, o que a torna um substrato temporário para o crescimento e desenvolvimento de células. Seu grau de cristalinidade influenciará diretamente na sua degradação, sendo que quanto mais cristalina, menor será sua taxa de degradação/reabsorção, e com isso, maior durabilidade no corpo. Além disso, uma das características importantes para o sucesso dos scaffolds/implantes é sua porosidade, pois, os poros aumentam sua área de superfície, levando há uma melhor ligação e fixação com as células e tecidos (IBRAHIM et al., 2017; HAIDER et al., 2017).

Um grande desafio hoje é a utilização de HAp como biomateriais implantados para áreas que precisam de esforço mecânico, como quadris e joelhos, pois apresenta fragilidade e baixas propriedades mecânicas. Outro desafio é utilizar as técnicas de fabricação corretas para as propriedades finais desejadas (IBRAHIM et al., 2017).

Há duas principais rotas para síntese de hidroxiapatita, sendo elas por vias úmidas ou secas. Os métodos por via seca (reações no estado sólido) ocorrem com o uso de alta temperatura ou com auxilio mecânico (pressão). Os métodos úmidos apresentam um melhor controle da morfologia e dos tamanhos das partículas, sendo os mais comuns precipitação química, tratamento hidrotérmico, eletrofiação, electrospray, irradiação por micro-ondas, emulsão, precipitação com emulsificante e vapor químico (RATNAYAKE; MUCALO; DIAS, 2016; QI et al., 2017a; HAIDER et al., 2017).

Todos esses métodos resultam em diferentes morfologias e composições químicas. Nos métodos úmidos controla-se mais facilmente a relação estequiométrica entre $\mathrm{Ca} / \mathrm{P}$. Se a mesma não for 1,67, ocorrerá a precipitação de outras fases, como por exemplo, TCP (trifosfato de cálcio). O controle simultâneo da nucleação, cristalização e aglomeração é complexo e requer cuidados no preparo. (RATNAYAKE et al., 2016; HAIDER et al., 2017) $\mathrm{Na}$ Tabela 5 é possível observar os principais parâmetros de controle para os métodos mais utilizados na produção de HAp. 
Tabela 5 - Principais técnicas e características da HAp final

\begin{tabular}{c|c|c|c|c}
\hline Método & $\begin{array}{c}\text { Temperatura de } \\
\text { preparo }\left({ }^{\circ} \mathbf{C}\right)\end{array}$ & $\begin{array}{c}\text { Grau de } \\
\text { Cristalinidade }\end{array}$ & $\begin{array}{c}\text { Tamanho da } \\
\text { partícula }(\boldsymbol{\mu})\end{array}$ & $\begin{array}{c}\text { Custo de } \\
\text { processo }\end{array}$ \\
$\begin{array}{c}\text { Precipitação } \\
\text { química }\end{array}$ & 25 & Baixo & $>0,1$ & Baixo \\
Hidrotérmico & $150-400$ & Alto & $>0,05$ & Alto \\
Sol-Gel & $37-85$ & Variável & $>0,001$ & Variável \\
Reações no & $1050-1250$ & Alto & $>2,0$ & Baixo \\
\hline
\end{tabular}

Fonte: Adaptado de Shojai et al. (2013) e Haider et al. (2017)

\subsection{Biopolímeros}

O uso de polímeros na engenharia de tecidos vem sendo amplamente estudado em laboratórios e aplicações clínicas. O emprego desses apresenta algumas vantagens em relação às demais classes devido a sua biocompatibilidade, boas propriedades mecânicas, microestrutura, taxa de degradação controlável e fácil processabilidade. Eles podem ser de origem sintética ou natural. (SABIR et al., 2009; SIONKAWSKA, 2011)

Os polímeros biodegradáveis sintéticos oferecem algumas vantagens em relação aos de origem natural, pois podem ser sintetizados de maneira a incrementar suas propriedades, além de apresentarem maior uniformidade e reprodutibilidade em sua estrutura. Porém, podem apresentar respostas imunes devido à presença residual de seus precursores ou iniciadores (SABIR et al., 2009; SIONKAWSKA, 2011; REBELO; FERNANDES; FANGUEIRO, 2017).

Já os polímeros naturais são ótimos suportes para aderência e crescimento celular, pois permitem o estímulo de resposta celular no mesmo tempo que implantado. Apresentam estrutura altamente organizada e contém substâncias da matriz extracelular. Porém, sua reprodutibilidade e processabilidade são mais complexas, possuem menor resistência mecânica que os polímeros sintéticos e suas taxas de degradação podem variar de paciente para paciente devido ao envolvimento de enzimas necessárias para degradação presentes em cada indivíduo. (SABIR et al., 2009; SIONKAWSKA, 2011; REBELO; FERNANDES; FANGUEIRO, 2017) 
Os principais biopolímeros utilizados no preparo de materiais para aplicação biomédica são: colágeno, quitina, quitosana, queratina, elastina e fibroína de seda, todos derivados de animais. Há também os de origem vegetal que podem ser utilizados, sendo eles, pectina, celulose e amido (SIONKAWSKA, 2011).

\section{Fibroína de seda}

A seda é historicamente reconhecida por suas características únicas, principalmente resistência mecânica e estabilidade térmica. Médicos e cirurgiões utilizam-na há séculos como material de sutura, e recentemente, ela vem ganhando um grande destaque como biomaterial. Suas excelentes propriedades, como biocompatibilidade, facilidade de modificação química, baixa taxa de degradação in vivo e habilidade de ser processada em diferentes formatos a partir de soluções aquosas ou solventes orgânicos, a tornam um material de grande interesse biotecnológico. (ROCKWOOD et al., 2011; QI et al., 2017b)

Produzida na glândula posterior do bicho da seda (Bombyx Mori), a seda é formada por duas principais estruturas, a fibroína de seda (FS) e a sericina. A sericina é uma glicoproteína hidrofílica que reveste a FS (Figura 5A). Durante o processo de purificação dos casulos, a sericina é removida devido à possibilidade de gerar respostas imunes ao corpo humano, embora alguns pesquisadores reportem que a sericina auxilia na proliferação celular e na melhoria de feridas causadas por queimaduras. Uma vez que a sericina é removida, a fibroína de seda dissolvida pode ser processada em diferentes estruturas, como mostrado na Figura 5B (ROCKWOOD et al., 2011; MOTTAGHITALAB et al., 2015). 
Figura 5 - (A) Seda: Origem e composição (B) Diferentes estruturas possíveis para fibroína de seda

(A)

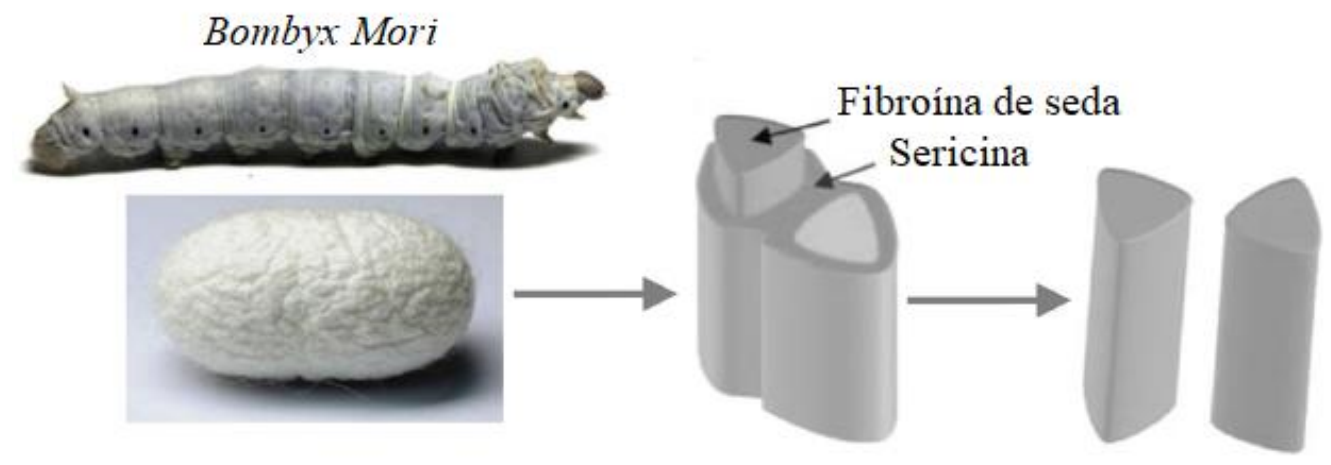

Fibroína de seda

(B)

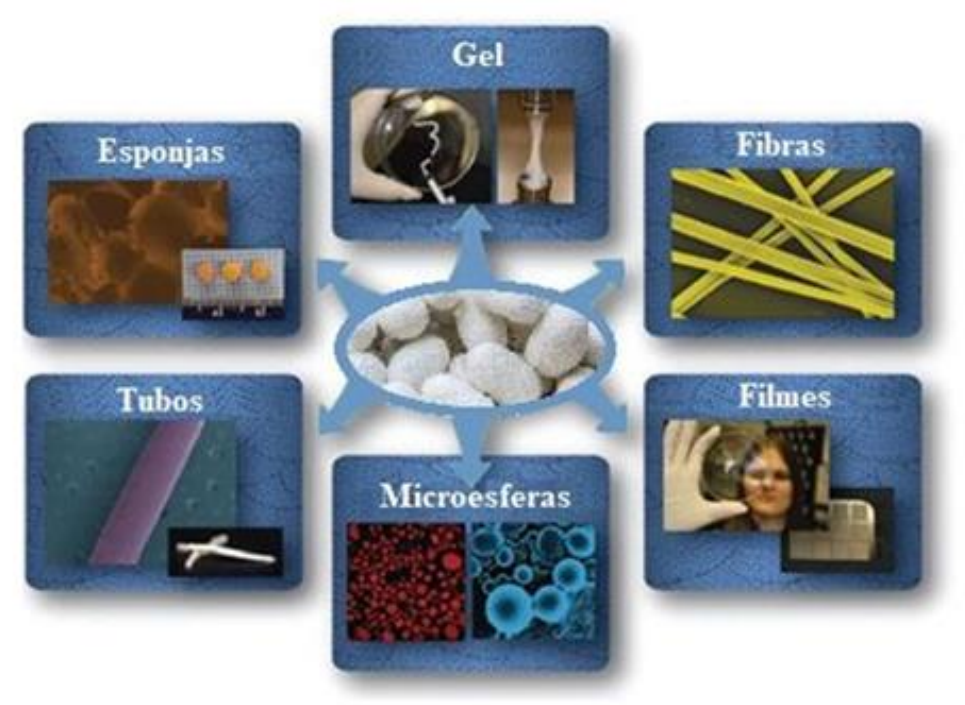

Fonte: adaptado de Koh et al. (2015) e Rockwood et al. (2011)

A fibroína de seda (FS) é um copolímero composto por duas cadeias, uma de baixa massa molecular $(\sim 26 \mathrm{kDa})$, e a outra de alta massa molecular $(\sim 390 \mathrm{kDa})$, ligadas por ligações de dissulfeto na terminação - $\mathrm{C}$ das cadeias de alta massa molecular. A cadeia de alta massa molecular, hidrofóbica, é uma sequência repetitiva de glicina (GLY)-alanina (ALA) serina (SER), formada por folhas cristalinas (folhas-ß) que conferem a resistência mecânica (Figura 6). A sequência das cadeias de baixa massa molecular não é repetitiva, é hidrofílica e apresenta baixa cristalinidade. Na Figura 6 encontra-se o esquema da sequência de amino ácidos presentes na cadeia de alta massa molecular. (ROCKWOOD et al., 2011; MANDAL et al., 2012; MOTTAGHITALAB et al., 2015) 
Figura 6 - Sequência de amino ácidos da cadeia de alta massa molecular da FS<smiles>CC(NC(=O)CNC(=O)C(C)NC(=O)CNC(=O)C(CO)NC(=O)CNC(C)(C)C)C(=O)O</smiles>

Fonte: Adaptado de Qi et al. (2017b)

A alta cadeia molecular, com repetitividade de aminoácidos, é capaz de se auto organizar em folhas cristalinas através de ligações intramoleculares e intermoleculares (ligação de hidrogênio e força de Van Der Waal) formando regiões altamente organizadas de maneira paralela e antiparalela, apresentando uma estrutura estável, com conformação espacial em zig-zag (KOH ET AL., 2015). O esquema da conformação paralela e antiparalela pode ser observada na Figura 7.

Figura 7 - Esquema representativo da estrutura de folhas-ß presente na FS

\section{Folhas- $\beta$ paralelas}

$\mathrm{C} \leftarrow \mathrm{N}$

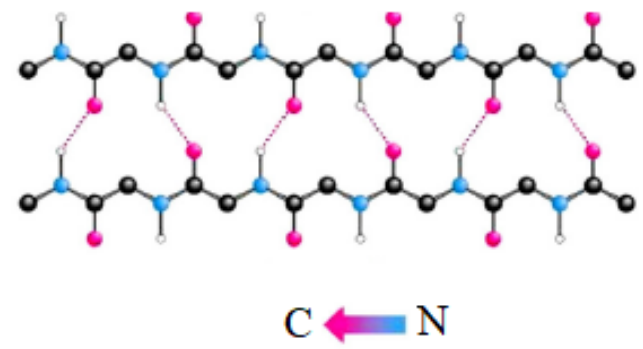

- Carbono Oxigênio
Folhas- $\beta$ antiparalelas

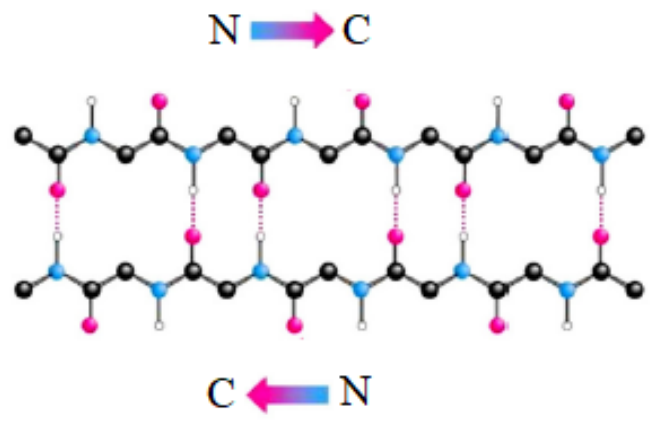

Nitrogênio

Fonte: Adaptado de Koh et al. (2015)

As três estruturas cristalinas presentes na fibroína de seda são do tipo I, II e III. A I, também conhecida como $\alpha$-hélice, pode ser facilmente convertida em II através de mudanças de temperatura e efeitos de solventes como metanol e cloreto de potássio. Já a estrutura II, refere-se ao arranjo de folhas- $\beta$ antiparalelas, e é a grande responsável pela resistência mecânica da fibroína e pela cristalinidade. A estrutura III é instável e difícil de ser observada, se apresenta na forma helicoidal em interface de ar e água (MOTTAGHITALAB et al., 2015; QI et al., 2017b). A estrutura da FS pode ser observada na Figura 8. 
Figura 8 - Estrutura da FS

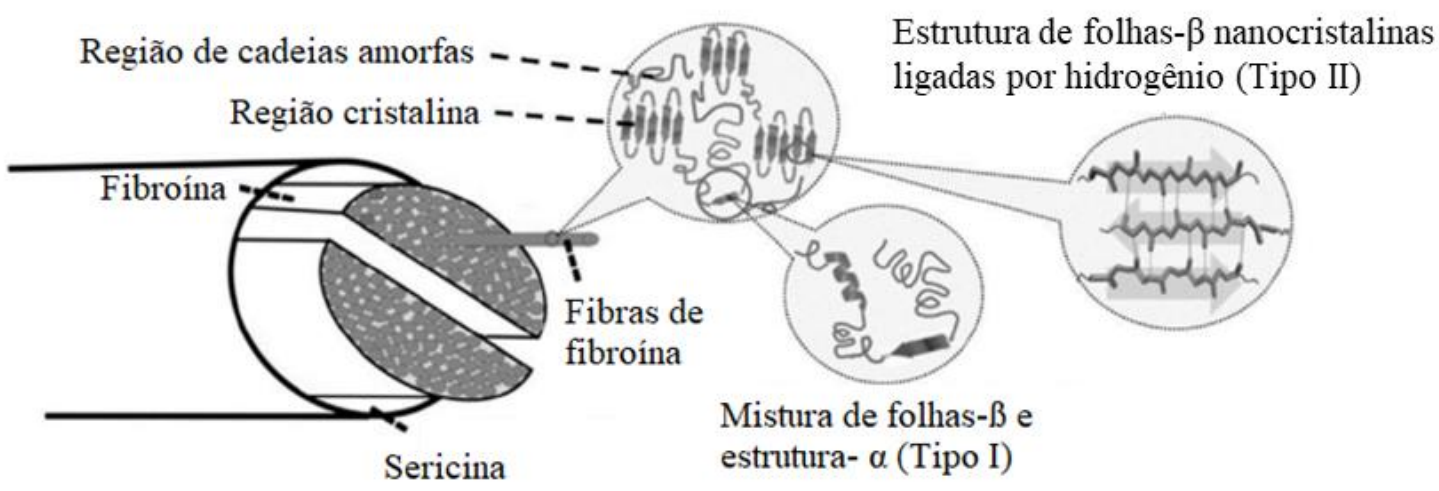

Fonte: Adaptado de Qi et al. (2017b)

Além de suas excelentes propriedades mecânicas, a FS também é um material biodegradável. FS altamente cristalizada degrada em taxas mais lentas, porém as taxas de degradação são dependentes do local implantado, do esforço mecânico exigido e do processamento aplicado para produzi-la. No geral, a taxa de degradação aumenta ou diminui de acordo com a presença de folhas- $\beta$ (devido a sua cristalinidade), porém é conhecido que ela pode ser afetada diretamente pelo metabolismo do hospedeiro do material implantado. (ROCKWOOD et al., 2011)

FS possui diversas características que a tornam aplicável em diferentes campos de atuação. Por exemplo, sua flexibilidade é ótima para produzir scaffolds porosos, enquanto que sua resistência à tração é ideal para fios de sutura. Sua resistência mecânica é superior aos polímeros biodegradáveis convencionais, tais como, colágeno, quitosana e ácido hialurônico, tornando-a uma excelente candidata para aplicações na engenharia de tecido ósseo. Na Tabela 6 encontra-se as características mecânicas de FS e demais fibras poliméricas (ROCKWOOD et al., 2011; MOTTAGHITALAB et al., 2015). 
Tabela 6 - Características mecânicas FS e demais fibras poliméricas

\begin{tabular}{c|c|c}
\hline Material & Módulo de Young (GPa) & $\begin{array}{c}\text { Resistência à tração } \\
\text { (MPa) }\end{array}$ \\
Fibroína de seda & $10-17$ & $300-700$ \\
Colágeno & $0,0012-0,046$ & $0,9-7,4$ \\
Nylon & $1,8-5$ & $430-950$ \\
Lã & 0,5 & 200 \\
Polipropileno & 4,6 & 360 \\
\hline
\end{tabular}

Fonte: Koh et al. (2015)

\subsection{Biocompósitos}

Devido ao rápido desenvolvimento de novas tecnologias biomédicas, incluindo a engenharia de tecidos, medicina regenerativa, terapia de genes e liberação de fármacos, novos materiais estão sendo desenvolvidos para atender as especificidades requeridas nesses diferentes campos de atuação. Materiais convencionais (somente um componente), como polímero, metais ou cerâmicas, não são satisfatórios (RAMAKRISHNA et al., 2001; SAILAJA et al., 2016; DZIADEK; STODOLAK-ZYCH; CHOLEWA-KOWALSKA, 2017).

Com o objetivo de atender os requisitos de biocompatibilidade, biodegradabilidade e propriedades mecânicas, há uma necessidade de obter materiais completos com funções avançadas. Por exemplo, um material multifuncional para engenharia de tecido ósseo deve induzir a formação do osso sem a adição de fator de crescimento orgânico, como BMP (proteína morfogenética do osso), degradar progressivamente de acordo com a taxa de regeneração do novo tecido, induzir a formação de vasos sanguíneos e, ainda, exibir atividade antibacteriana e anti-inflamatória. Portanto para isso, o suporte ideal será possível através do design e desenvolvimento de materiais com multicomponentes, ou seja, os compósitos (RAMAKRISHNA et al., 2001; SAILAJA et al., 2016; DZIADEK; STODOLAK-ZYCH; CHOLEWA-KOWALSKA, 2017).

Além disso, os tecidos humanos são essencialmente compósitos com propriedades anisotrópicas, que dependem dos papéis e estruturas de vários componentes, por exemplo, 
colágeno, elastina e hidroxiapatita. Sugere-se, portanto, que os materiais compostos ofereçam um maior potencial de biocompatibilidade e estrutura do que os homogêneos (RAMAKRISHNA et al., 2001; SAILAJA et al., 2016; DZIADEK; STODOLAK-ZYCH; CHOLEWA-KOWALSKA, 2017).

A hidroxiapatita é amplamente utilizada para preparar compósitos de matriz cerâmica e reforços poliméricos, com o objetivo de conferir bioatividade, osteocondutividade e melhorar as propriedades mecânicas (a presença de HAp aumenta a resistência à compressão e o módulo de Young). As fases orgânicas-inorgânicas possuem propriedades muito especiais, permitindo a indução da mineralização biomimética e a formação de estruturas autoorganizadas. Se desenvolvidas corretamente abordam muitos desafios biomédicos existentes atualmente (RAMAKRISHNA et al., 2001; SAILAJA et al., 2016; DZIADEK; STODOLAKZYCH; CHOLEWA-KOWALSKA, 2017).

Atualmente na literatura encontram-se diversos trabalhos propondo biomateriais para uso na engenharia tecidual. Esses trabalhos envolvem hidroxiapatita, fibroína de seda ou, ambas juntas, formando um biocompósito. Há estudos em que os materiais desenvolvidos focam na estrutura física, envolvendo a avaliação dos poros e porosidade, e resistência à compressão, como também há estudos com foco somente no processamento do material.

Charrière, Lemaitre e Zysset (2003), por exemplo, estudaram o processamento de scaffolds macroporosos formados somente por hidroxiapatita através de precipitação e em seguida moldada em estrutura 3D utilizando um molde de sacrifício. As amostras foram aquecidas a $90^{\circ} \mathrm{C}$ durante $24 \mathrm{~h}$ para sua completa formação. O processo desenvolvido nesse estudo foi capaz de gerar scaffolds com porosidade de 56\%, porém com baixa interconectividade, e, com resistência à compressão mecânica de 12,5 \pm 4,6 MPa.

Outro trabalho focado em scaffolds porosos de hidroxiapatita foi desenvolvido por Real et al. (2002). Em seus estudos os suportes com porosidade de 51,8\% (tamanho de poros entre $0,3 \mu \mathrm{m}$ até $300 \mu \mathrm{m}$, sendo $50 \%$ deles com $10 \mu \mathrm{m}$ ) apresentaram resistência à compressão de 2,1 \pm 0,3 MPa. Já Landi et al. (2003) tiveram o mesmo objetivo, porém utilizando hidroxiapatita carbonatada, resultando em resistências de 6,0 $\pm 0,5 \mathrm{MPa}$.

Gil et al. (2011) estudaram a resistência mecânica de scaffolds produzidos com fibroína de seda. Em seu trabalho dois tipos de suportes foram estudados, um contendo solução de fibroína + Hexafluoroisopropanol e o segundo contendo o mesmo, porém adicionando fibroína de seda em pó. A porosidade encontrada foi entre $92,7 \pm 0,9 \%-74,6 \pm 0,9 \%$, com 
tamanho de até $300 \mu \mathrm{m}$. Concluiu-se que a resistência mecânica aumenta com o aumento do pó de fibroína de seda adicionado. Amostras somente com solução de 16\% do polímero, apresentou a menor resistência mecânica, sendo essa de 0,47 $\pm 0,33 \mathrm{MPa}$, porém a maior resistência encontrada em seu estudo foi de 5,10 \pm 0,41 $\mathrm{MPa}$ em amostras com solução de $32 \% \mathrm{FS}+320 \mathrm{mg}$ do polímero em forma de pó.

Estudos como o de Fan et al. (2010) e Zakharov et al. (2017) focaram na fabricação de compósitos de FS e HAP através do processo de precipitação. O primeiro aproveita os sais de cálcio presentes na solução ternária $\left(\mathrm{CaCl}_{2}\right.$, etanol e água) utilizada na dissolução de fibroína de seda. Já o segundo utilizou uma metodologia em que se adiciona soluções de $\left(\mathrm{NH}_{4}\right)_{2} \mathrm{HPO}_{4}$ e $\mathrm{Ca}\left(\mathrm{NO}_{3}\right)_{2}$ em suspensão de fibroína de seda hidrolisada em $\mathrm{NaOH}$. Ambos encontraram diferenças entre a morfologia de hidroxiapatita pura e a do compósito com fibroína de seda, sendo que as amostras preparadas somente com cerâmica apresentaram estruturas em forma de bastões não aglomerados. Já as amostras com a presença de fibroína de seda exibiram empacotamento e ligação com a hidroxiapatita.

Em outro estudo realizado por Wang e Li (2007) também se observa a morfologia aglomerada quando se tem a interação de hidroxiapatita e fibroína de seda. Nesse trabalho, o composto foi preparado a partir de solução de $\mathrm{Ca}(\mathrm{OH})_{2}$ e $\mathrm{H}_{3} \mathrm{PO}_{4}$, fibroína de seda e quitosana, ambas em pó. Novamente a fotomicrografia revelou uma diferença entre a hidroxiapatita pura e o compósito estudado. As partículas de HAp pura, apresentam formas de agulhas e dispersas. Quando se observa a morfologia da composição entre HAp + FS + Quitosana, não há alteração na forma de agulha da cerâmica, porém as partículas agora se apresentam agregadas umas às outras. Nesse trabalho, assim como o de Fan et al. (2010) e Zakharov et al. (2017), o foco foi a metodologia para a fabricação do composto, sendo que não houve a conformação de scaffolds 3D.

Gholipourmalekabadi et al. (2015) estudaram a formação de matrizes 3D de compostos com hidroxiapatita e fibroína de seda. Os scaffolds foram processados através da metodologia de liofilização. As micrografias indicaram tamanhos de poros de $350 \pm 67 \mu \mathrm{m}$ para amostras com $5 \%$ de fibroína de seda, e $112 \pm 89 \mu \mathrm{m}$, para amostras com $10 \%$ do polímero. O aumento da \% de FS torna os poros condensados e compactados em orifícios menores. Em seu estudo, e em outros citados no mesmo trabalho, concluiu-se que o aumento da quantidade do polímero tende a diminuir o tamanho dos poros.

Wang, Nemoto e Senna (2004) analisaram a porosidade de diferentes concentrações de 
HAp + FS em modelos 3D. Os scaffolds foram processados através de prensagem, a $98 \mathrm{MPa}$, de pós com misturas de hidroxiapatita e fibroína de seda nas proporções de 90/10, 80/20, 70/30 e 60/40. Os poros encontrados possuem distribuição entre 40-115 $\mu \mathrm{m}$. O compósito apresenta aumento de densidade conforme acrescenta-se maior quantidade do polímero, devido a ligação entre as partículas de hidroxiapatita aglomeradas e as fibrilas da proteína da seda.

Park et al. (2015) avaliou scaffolds 3D de hidroxiapatita e fibroína de seda processados a partir da mistura de $\mathrm{HAp}+\mathrm{FS}$, acrescentando uma camada de $\mathrm{NaCl}$ ou sacarose para incremento da porosidade. Ele relatou em seus estudos uma porosidade acima de $65 \%$ e absorção de líquido acima de $83 \%$, essa atribuída a estrutura interconectadas dos poros, o que promove morfologia adequada para o crescimento celular.

Em outro estudo realizado por Lin et al. (2008), os scaffolds foram formados a partir do gotejamento de solução de fibroína de seda em solução de nano-hidroxiapatita, após as partículas foram ligadas com glutaraldeído e liofilizadas. Todas as proporções estudadas (70\%, 60\%, 30\%, 10\% e 0\% de HAp) apresentaram porosidade acima de 40\%, sendo que quanto maior a quantidade de HAp, maior a porosidade. Já a capacidade de absorção de líquidos diminui com o aumento de HAp acrescentada, devido ao aumento da densidade do suporte.

Alguns estudos focam na relação porosidade e resistência à compressão, como por exemplo, no trabalho de Liu et al. (2008) onde foi desenvolvido esponjas com várias \%HAp + $\%$ FS através de liofilização. Concluiu que as amostras com 70\%HAp+30\%FS exibiram resistência mecânica de $0,4 \mathrm{MPa}$ e porosidade de $61,1 \% \pm 1,6$. O aumento do material inorgânico causa uma modificação na morfologia dos poros, causando rugosidade, o que auxilia na adesão celular e proliferação.

Teimouri et al. (2015) também desenvolveram trabalhos envolvendo FS e HAp formando esponjas por liofilização, porém agregando gelatina aos compósitos. Novamente se observa a mudança na estrutura dos poros para uma superfície mais rugosa. A amostras com $70 \%$ de material inorgânico e 30\% orgânico apresentaram resistência de 0,9 MPa com porosidade de $50 \%$.

Outro trabalho com liofilização foi desenvolvido por Qi et al. (2014), os seus compósitos formados com quitosana (1\%), fibroína de seda $(1 \%)$ e hidroxiapatita $(0,5 \%)$ foram pré-preparados com sais de $\mathrm{NaCl}$. As amostras com FS e HAP apresentaram resistência 
mecânica de 4,5 MPa, com porosidade de 95\%. Quando adicionado quitosana a mistura, apresentam resistência de 6,5 MPa e porosidade semelhante.

A grande maioria dos trabalhos para o desenvolvimento de scaffolds 3D de HAP e FS apresentam o uso de metodologias complexas, como por exemplo a liofilização. Há uma oportunidade de se aprimorar um biocompósito focando nas estruturas físicas e químicas mais próximas ao osso trabecular e processadas de maneira simplificada, com custo reduzido. Nesse contexto, o presente estudo se faz necessário para que novas possiblidades sejam obtidas para materiais substitutos do tecido ósseo. 


\section{MATERIAIS E MÉTODOS}

\subsection{Obtenção, Purificação e Solubilização da Fibroína de Seda}

A fibroína de seda foi obtida a partir dos casulos do bicho-da-seda (Bombyx mori) de classe I sem as crisálidas, que foram fornecidos pela empresa BRATAC, Bastos, SP. Os casulos foram tratados com solução aquosa fervente de carbonato de sódio com concentração de $5 \%(\mathrm{~g} / \mathrm{g})$, durante 30 minutos para extração da sericina. Em seguida, a fibroína foi lavada com água desionizada três vezes a cada $1 \mathrm{~h}$, mantendo em água entre as lavagens. A fibroína lavada foi colocada em placa de Petri para secagem a $60^{\circ} \mathrm{C}$, por $48 \mathrm{~h}$. Para solubilização da fibroína foi utilizada metodologia desenvolvida por Ajisawa A. (1969) utilizando solução ternária contendo cloreto de cálcio, água destilada e etanol na proporção molar de 1:2:8 $\left(\mathrm{CaCl}_{2}: \mathrm{EtOH}: \mathrm{H}_{2} \mathrm{O}\right)$, com $10 \%(\mathrm{~g} / \mathrm{g})$ de fibroína sobre agitação magnética até dissolução completa da fibroína a $80^{\circ} \mathrm{C}$. Após o resfriamento, a solução foi passada por peneira de 60 mesh para extração de impurezas. A solução foi utilizada logo em seguida ao seu preparo (Figura 9).

Figura 9 - Metodologia para preparo de solução de FS

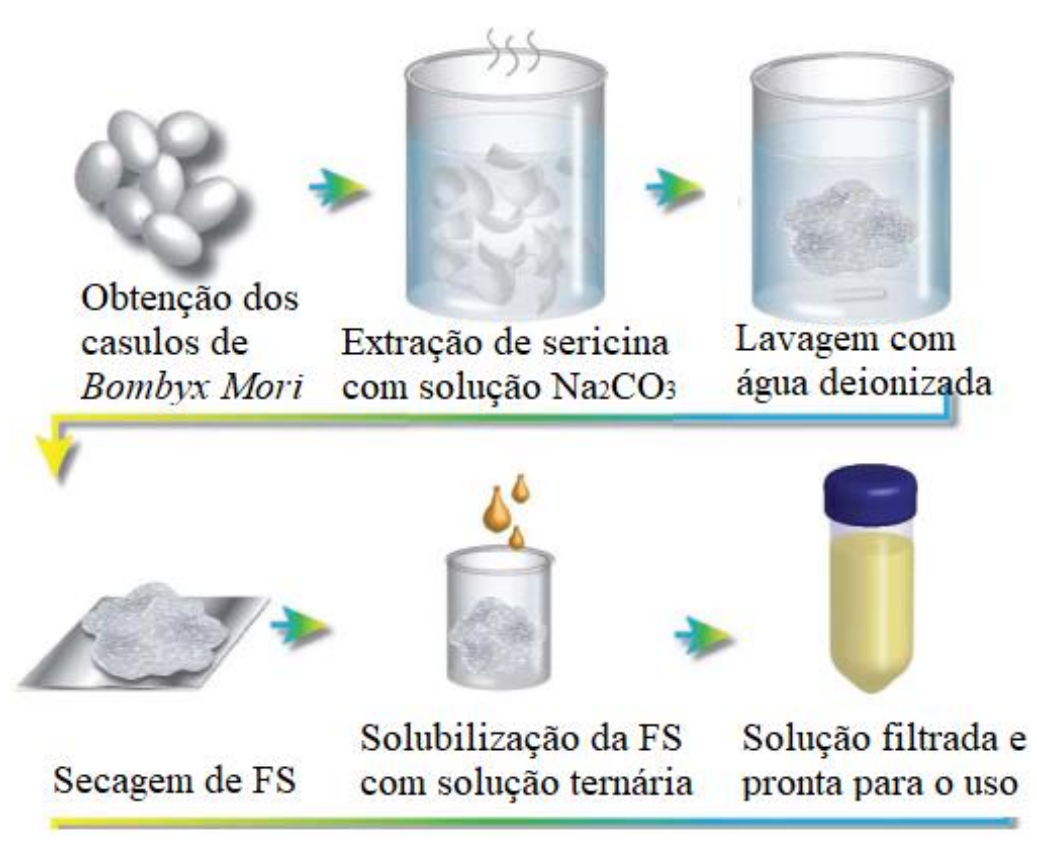

Fonte: Elaborado pela autora

\subsection{Obtenção do biocompósito}

A obtenção da hidroxiapatita ocorreu através do processo de precipitação (Equação I). A solução de fosfato dissódico $\left(\mathrm{Na}_{2} \mathrm{HPO}_{4}\right)$, tamponada com tampão Tris-hidróxi- 
metilaminometano (Tris-HCl) $0,05 \mathrm{~mol} \mathrm{~L}^{-1}$ e pH 9,0, foi gotejada na solução de fibroína de seda dissolvida. Realizou-se o processo em diferentes proporções (contendo de 65\%, 75\%, $85 \%$ e $95 \%$ de hidroxiapatita) a fim de se obter o biocompósito mais adequado para um substituto ósseo. A homogeneização ocorreu com agitação mecânica (10.000 RPM) durante 30 minutos.

$$
6 \mathrm{HPO}_{4}^{-2}+10 \mathrm{Ca}^{+2}+2 \mathrm{OH} \leftrightarrow \mathrm{Ca}_{10}\left(\mathrm{PO}_{4}\right)_{6}(\mathrm{OH})_{2}
$$

Para os testes iniciais a formação de blocos cilíndricos $(9 \mathrm{~mm}$ de diâmetro e $10 \mathrm{~mm}$ de altura) foi realizada através de prensagem manual com o objetivo de definir a melhor \%HAp. Com a definição da composição $75 \% \mathrm{HAp}+25 \% \mathrm{FS}$, os biocompósitos foram prensados através de prensa hidráulica (Prensa MAXX - 3 toneladas, Essence Dental) em moldes de aço inox com força de compactação de 50 e $100 \mathrm{MPa}$ (A definição da composição das amostras será explicada na seção 6.1). Após a formação dos blocos dos biocompósitos (9 mm de diâmetro e $10 \mathrm{~mm}$ de altura), os mesmos foram secos a $60^{\circ} \mathrm{C}$ por $48 \mathrm{~h}$. Os blocos secos foram lavados com água deionizada, para retirada de sais solúveis em água por 48h, sobre agitação constante e com troca de água a cada $4 \mathrm{~h}$. Por último, os blocos foram secos durante $48 \mathrm{~h}$ a $60^{\circ} \mathrm{C}$ (Figura $10)$.

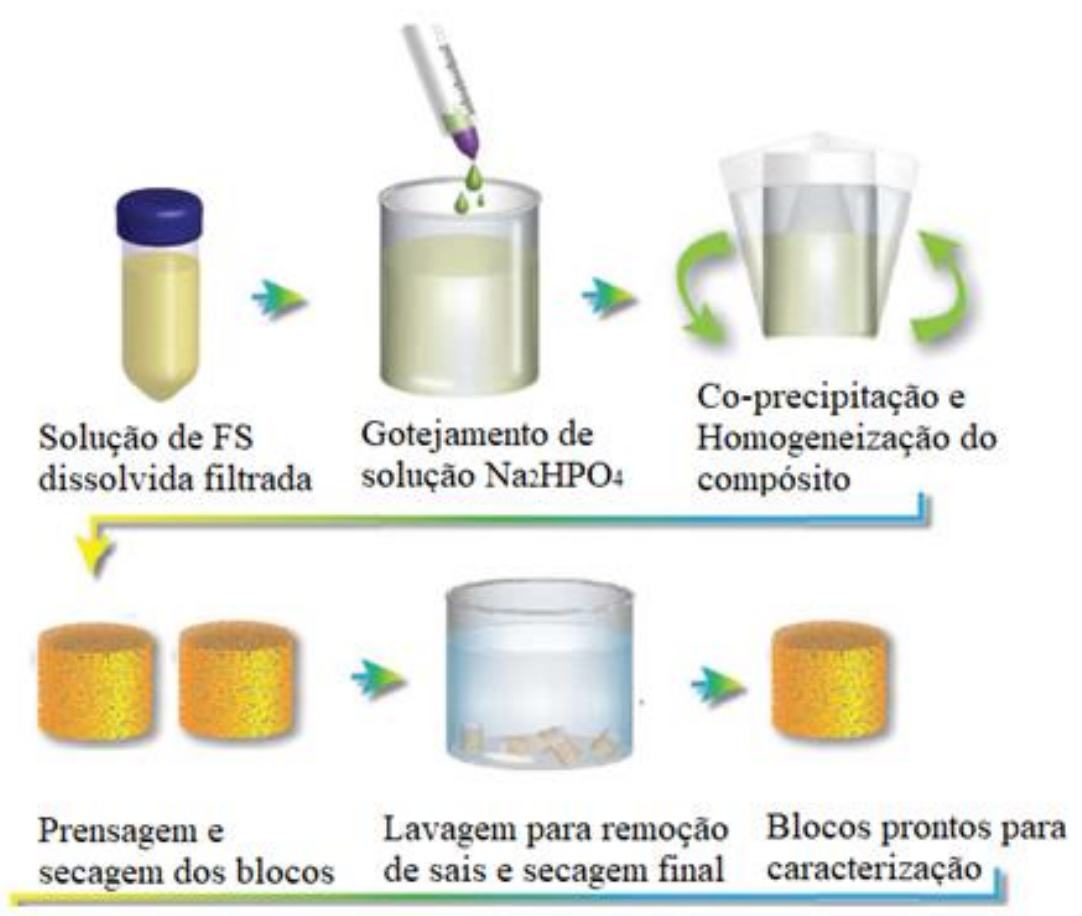

Fonte: Elaborado pela autora 


\subsection{Caracterizações dos biocompósitos obtidos}

Foram realizadas as seguintes análises físico-químicas dos biocompósitos formados por hidroxiapatita e fibroína de seda:

\subsubsection{MICROSCOPIA ELETRÔNICA DE VARREDURA (MEV)}

As fotomicrografias de MEV foram obtidas na Central de Análises Químicas Instrumentais do Instituto de Química de São Carlos (CAQI/IQSC/USP) em um equipamento ZEISS LEO 440 (Cambridge, England) com detector OXFORD (model 7060), operando com feixe de elétrons de $20 \mathrm{kV}$, corrente de 2,82 A e I probe de $200 \mathrm{pA}$. As amostras foram recobertas com carbono em um metalizador Coating System BAL-TEC MED 020 (BAL-TEC, Liechtenstein) e mantidas em dessecador até o momento de análise.

\subsubsection{DISPERSÃO DE ENERGIA POR RAIOS-X (EDS)}

EDS foi utilizado para determinação da composição qualitativa e semi- quantitativa das amostras através de emissão de raios X. A análise de EDS foi realizada em um equipamento EDS LINK ANALYTICAL, (Isis System Series 200), na Central de Análises Químicas Instrumentais do Instituto de Química de São Carlos (CAQI/IQSC/USP), com detector de SiLi Pentafet, janela ultrafina ATW II (Atmosphere Thin Window), de resolução de $133 \mathrm{eV}$ à 5,9 keV, acoplado a um Microscópio Eletrônico LEO 440 (LEO Electron Microscopy Ltd), com um detector Oxford (Oxford Instruments Inc.). Foi utilizado o padrão de Co para calibração, feixe de elétrons de $20 \mathrm{kV}$, distância focal de $25 \mathrm{~mm}$, "dead time" de $30 \%$, corrente de 2,82 A e I "probe" de 950 pA.

\subsubsection{ANÁLISE TERMOGRAVIMÉTRICA (ATG)}

Através da análise termogravimétrica verificou-se o comportamento de decomposição térmica do biocompósito formado por hidroxiapatita e fibroína de seda e quantificação da fase mineral e orgânica do mesmo. As medidas foram realizadas de 25 até $800{ }^{\circ} \mathrm{C}$, em atmosfera de ar sintético, com amostras de aproximadamente $10 \mathrm{mg}$ e taxa de aquecimento de $10{ }^{\circ} \mathrm{C} \mathrm{min}^{-1}$ em um equipamento de TGA, modelo Q-50 da TA Instruments, pertencente a Análises Químicas Instrumentais do Instituto de Química de São Carlos (CAQI/IQSC/USP).

\subsubsection{ESPECTROSCOPIA NO INFRAVERMELHO POR TRANSFORMADA DE FOURIER (FTIR)}

O espectro de absorção na região do infravermelho foi realizado para analise estrutural através das vibrações dos grupos funcionais para verificar a presença de folha- $\beta$ ou $\alpha$-hélice. 
Foi utilizado um espectrofotômetro da Shimadzu IRAffinity-1 pertencente a Central de Análises Químicas Instrumentais do Instituto de Química de São Carlos (CAQI/IQSC/USP), com 64 scans e resolução de $4 \mathrm{~cm}^{-1}$, com faixa de número de onda utilizada de 400 a $4000 \mathrm{~cm}^{-1}$ com amostras em pastilhas de $\mathrm{KBr}$.

\subsubsection{PERCENTUAL DE POROSIDADE}

O total de porosidade foi calculado baseado no princípio de Arquimedes, com auxílio da norma NBR ISSO 5017. As amostras ( $\mathrm{n}=5)$ foram secas a $60{ }^{\circ} \mathrm{C}$ por $24 \mathrm{~h}$. E suas massas (M1) foram medidas em balança de precisão $0,01 \mathrm{mg}$. Em seguida foram colocadas em um recipiente com etanol. As amostras passaram por ciclos de desaeração para a completa absorção do etanol no interior dos blocos. Mediu-se a massa do bloco após completa imersão de etanol (M2). E por último, mede-se a massa do bloco imerso no álcool (M3) com auxílio de balança analítica mecânica. Dessa maneira, calcula-se a \% de absorção de líquidos (\%AL) através da equação II e a \% de porosidade aparente (\%PA) do bloco utilizando a equação III.

$$
\begin{aligned}
& \% A L=\frac{M 2-M 1}{M 2} \times 100 \\
& \% P A=\frac{M 2-M 1}{M 2-M 3} \times 100
\end{aligned}
$$

\subsubsection{RESISTÊNCIA Á COMPRESSÃO}

Foram realizados ensaios de compressão nos blocos das diferentes proporções de hidroxiapatita e fibroína de seda para identificar à que apresenta maior resistência à compressão. As amostras ( $\mathrm{n}=5)$ para esses ensaios foram modeladas em formas cilíndricas, com diâmetro de $9 \mathrm{~mm}$ e altura de $10 \mathrm{~mm}$. Os ensaios de compressão foram realizados utilizando o equipamento TIME GROUP $30 \mathrm{KN}$, no Laboratório de Ensaio Mecânico NEMAF/EESC/USP, utilizando células de carga de $5000 \mathrm{Kg}$, com velocidade de $0,5 \mathrm{~mm} / \mathrm{minuto}$.

\subsubsection{DIFRATOMETRIA DE RAIOS -X (DRX)}

A técnica de difração de Raio-X foi realizada para determinação de fases e cristalinidade do composto estudado. Os estudos foram executados em um difratômetro de raio-X Bruker D8 Discovery Instrument, utilizando como parâmetro de difração $2 \theta$ com 
deslocamento de $2 \%$ minuto tensão de $40 \mathrm{kv}$, corrente de $20 \mathrm{~mA}$, com varredura entre $5^{\circ}$ a $105^{\circ}$, com radiação $\mathrm{CuK} \alpha$. O ensaio foi desempenhado no laboratório de caracterização de materiais do Departamento de Engenharia de Materiais da Universidade de McGill, Montreal, Canadá.

\subsubsection{MICROTOMOGRAFIA COMPUTADORIZADA $(\mu \mathrm{CT})$}

Através da técnica de $\mu \mathrm{CT}$ é possível observar o biocompósito em imagens 3D, avaliando seu volume, porosidade e conectividade dos poros. As amostras foram escaneadas em equipamento Micro-CT SkyScan 1172 (SkyScan; Kontich, Belgium). A reconstrução das imagens foram realizadas usando NRecon (Version 1.6.2.0; SkyScan). Para o cálculo de porosidade e volume foi utilizado o software CT-Vol (SkyScan, August 2003, Aartselaar, Belgium). O ensaio foi realizado no laboratório de biomateriais do Instituto de Pesquisa Ortopédicas da Universidade McGill, Montreal/Canadá.

\subsection{9 ÁREA SUPERFICIAL ESPECÍFICA (BET)}

A definição da área superficial específica das amostras do biocompósito formado por hidroxiapatita e fibroína de seda foi obtida através da metodologia Brunauer-Emmet-Teller (BET), utilizando absorção de nitrogênio. Para isso, as amostras foram trituradas e secas por $24 \mathrm{~h}$ em vácuo para a eliminação de umidade. As amostras foram ensaiadas em equipamento Tristar 3000 (Micromeritics Instruments Corporation, Gerogia USA). O ensaio foi realizado no laboratório de caracterização de materiais do Departamento de Odontologia da Universidade de McGill, Montreal/Canadá.

\subsubsection{CITOTOXICIDADE}

Os ensaios de citotoxicidade são utilizados como o primeiro passo para comprovar biocompatibilidade de dispositivos médicos e materiais a serem implantados. $\mathrm{O}$ ensaio foi realizado de acordo com o método de incorporação de vermelho neutro baseado na norma ISO 10993-5 - Tests for in vitro cytotoxicity. Foram utilizadas células de ovário de hamster chinês $(\mathrm{CHO})$ para determinar a resposta biológica in vitro. O estudo foi realizado na Faculdade de Zootecnia e Engenharia de Alimentos, Departamento de Ciências Básicas, Universidade de São Paulo, campus de Pirassununga/SP.

\subsubsection{AVALIAÇÃO IN VITRO DA CAPACIDADE DE FORMAÇÃO DE APATITA}

A avaliação de formação de apatita se faz necessária para prever a capacidade de ligação do composto estudado com o osso in vivo antes de experimentos com animais. $\mathrm{O}$ 
ensaio foi realizado utilizando solução SBF (solução inorgânica que tem uma composição similar ao plasma sanguíneo humano sem componentes orgânicos). Para isso, foi utilizada a norma ABNT NBR ISO 23317 "Implantes para cirurgia - Avaliação in vitro da capacidade de formação de apatita de materiais de implante". A solução de SBF foi preparada dissolvendo sais de $\mathrm{NaCl}, \mathrm{NaHCO}_{3}, \mathrm{KCl}, \mathrm{K}_{2} \mathrm{HPO}_{4} \cdot 3 \mathrm{H}_{2} \mathrm{O}, \mathrm{MgCl}_{2} \cdot 6 \mathrm{H}_{2} \mathrm{O}, \mathrm{CaCl}_{2}$, e $\mathrm{Na}_{2} \mathrm{SO}_{4}$ em água destilada. A solução foi padronizada em $\mathrm{pH} \mathrm{7,4}$ a $36,5{ }^{\circ} \mathrm{C}$. Foi utilizada microscopia eletrônica de varredura para evidenciar a camada de apatita formada na superfície dos implantes. 


\section{RESULTADOS E DISCUSSÕES}

\subsection{Definição da relação orgânica/inorgânica do biocompósito}

Os testes preliminares foram efetuados para definir a relação de porcentagem de hidroxiapatita (HAp) e fibroína de seda (FS) mais adequada para um substituto ósseo. Os primeiros estudos foram feitos com a proporção orgânico/inorgânico de 35/65, 25/75, 15/85 e $5 / 95 \%(\mathrm{~g} / \mathrm{g})$. Para isso, o biomaterial foi caracterizado com os seguintes ensaios: porcentagem de absorção de álcool, onde o intuito era avaliar a interconectividade dos poros; microscopia eletrônica de varredura (MEV) para estudar morfologia do biocompósito; relação $\mathrm{Ca} / \mathrm{P}$ através de dispersão de raios-X (EDS) e ensaio de compressão mecânica a fim de avaliar a resistência das amostras. As amostras de 95\%HAp e 5\%FS se desagregaram no momento das lavagens para remoção dos sais solúveis em água, não sendo possível caracterizar as mesmas, logo, essa porcentagem foi descartada. Os resultados das demais proporções dos testes preliminares estão listados na Tabela 7.

Tabela 7 - Relação Ca/P, absorção de álcool e resistência à compressão para as amostras prensadas manualmente

\begin{tabular}{c|c|c|c}
\hline Amostra & Relação Ca/P & $\begin{array}{c}\text { \% Absorção de } \\
\text { álcool (g/g) }\end{array}$ & $\begin{array}{r}\text { Resistência à } \\
\text { compressão mecânica } \\
\text { (MPa) }\end{array}$ \\
65\%HAp+35\%FS & $1,89 \pm 0,01$ & $63,8 \pm 2,2$ & $0,25 \pm 0,11$ \\
$75 \%$ HAp+25\%FS & $1,67 \pm 0,15$ & $61,4 \pm 0,8$ & $0,36 \pm 0,01$ \\
\hline $85 \%$ HAp+15\%FS & $2,23 \pm 0,23$ & $58,8 \pm 1,5$ & $0,11 \pm 0,05$ \\
\hline
\end{tabular}

Fonte: Elaborado pela autora

Com os resultados dos testes preliminares a proporção $75 \% \mathrm{HAp}+25 \% \mathrm{FS}$ revelou um conjunto de resultados mais favoráveis para um possível substituto ósseo, possuindo a proporção de material inorgânico/orgânico mais próxima ao osso, uma relação $\mathrm{Ca} / \mathrm{P}$ mimética a hidroxiapatita e uma melhor resistência à compressão mecânica. Os estudos prosseguiram a partir dessa proporção. As amostras foram novamente confeccionadas utilizando prensa hidráulica para a padronização da força aplicada, com pressões de 50 e $100 \mathrm{MPa}$. Então, analisou-se novamente a morfologia do biocompósito, as características químicas e estruturais e os comportamentos térmico e mecânico.

Na Figura 11 é possível observar as fotomicrografias obtidas por MEV da amostra de 
$75 \%$ HAp + 25\% FS das amostras prensadas manualmente. Nota-se que a co-precipitação da HAp na solução de fibroína de seda ocorreu de forma homogênea, assim como nas demais proporções estudadas. Os poros, calculados através do software ImageJ, tiveram tamanhos entre 1-60 $\mu \mathrm{m}$, com interconectividade devido a formação de canais e pelo resultado de absorção de líquidos elevada.

Figura 11 - Fotomicrografias por MEV da amostra 75\%HAp25\%FS prensada manualmente
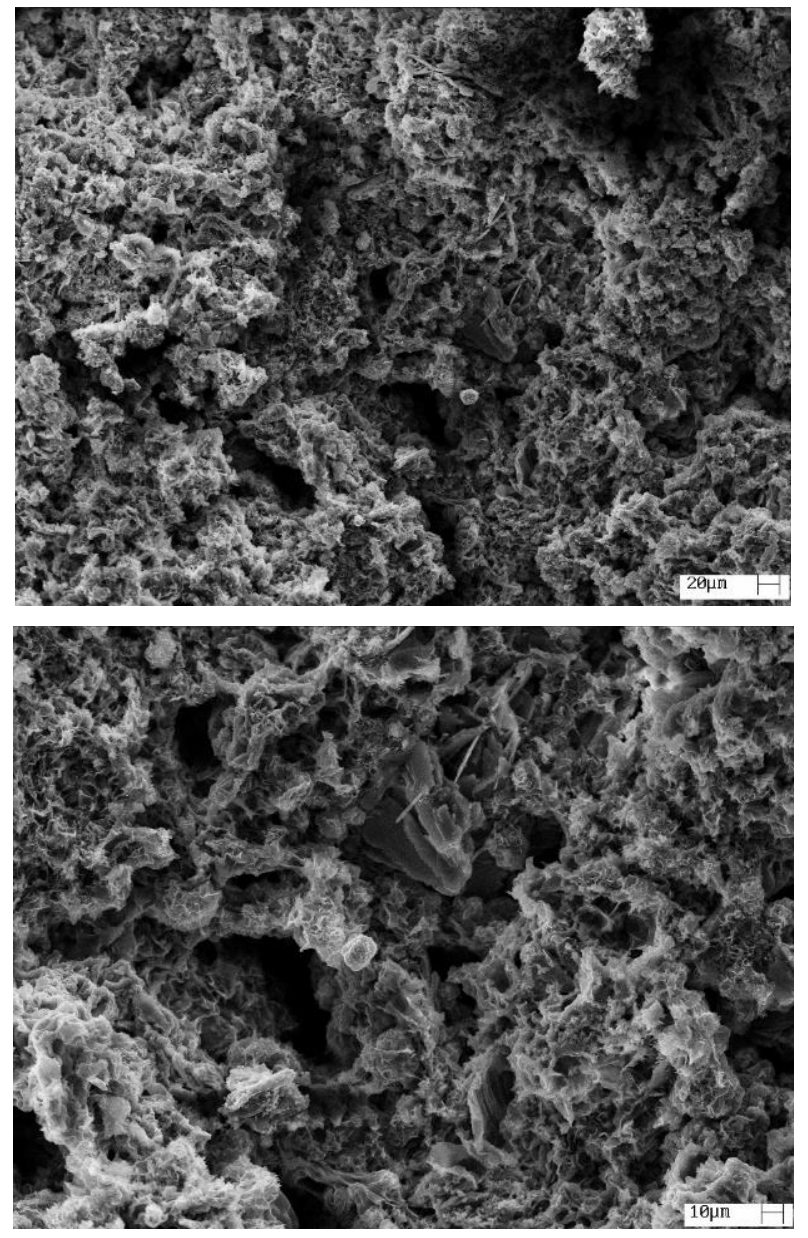

Fonte: Elaborado pela autora

\subsection{Microscopia eletrônica de varredura (MEV)}

A morfologia do scaffolds e de seus poros é um importante parâmetro a ser avaliado em materiais para substituição óssea. Estudos biológicos e clínicos demonstram que a interconexão dos poros é necessária para permitir a aderência, a proliferação e a diferenciação celular, além de providenciar caminhos aos biofluídos necessários para o crescimento do novo tecido e de vasos sanguíneos. (TEIMORI et al., 2015) (SIERRA et al., 2017)

As fotomicrografias do biocompósito estudado, $75 \% \mathrm{HAP}+25 \% \mathrm{FS}$, podem ser observadas nas Figuras 12 e 13. O número de poros e a estrutura, das amostras prensadas a 50 
e a $100 \mathrm{MPa}$, são similares, não sendo possível observar grandes diferenças entre as pressões utilizadas para a conformação dos blocos. Os scaffolds apresentam poros igualmente distribuídos com diâmetros entre 1 e $50 \mu \mathrm{m}$ (calculados através do software ImageJ) apresentando interconectividade. Nota-se ligação entre as partículas de fibroína de seda e hidroxiapatita, percebendo que elas estão conectadas entre si.

Figura 12 - Fotomicrografias do biocompósito prensado à 50MPa
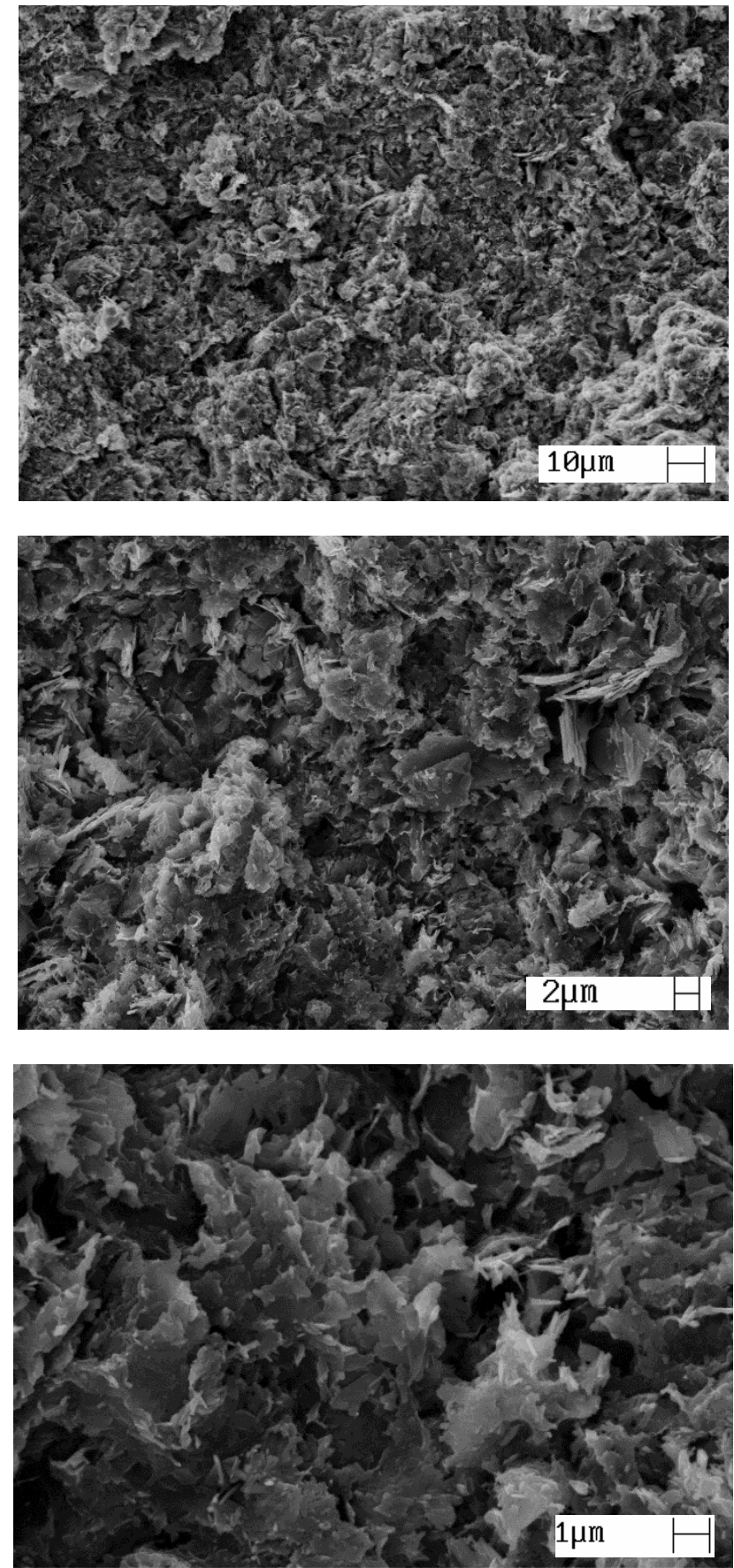

Fonte: Elaborado pela autora 
Figura 13 - Fotomicrografias do biocompósito prensado à 100MPa
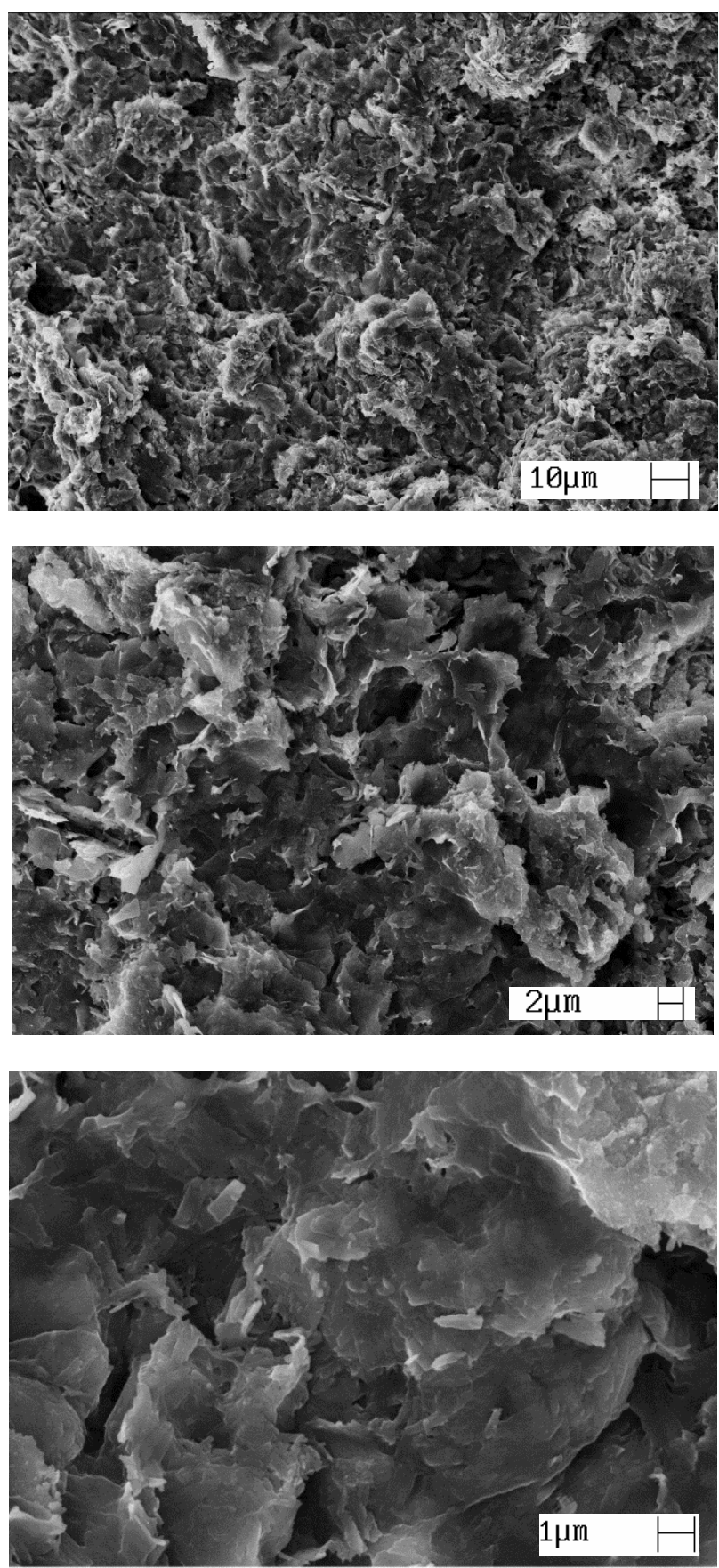

Fonte: Elaborado pela autora

A ligação entre as partículas de HAp e FS pode ser explicada devido ao grupo carbonila presente no polímero, o qual permite a ligação com os íons $\mathrm{Ca}^{+2}$, formando os complexos carbonila-cálcio (Figura 14). Ao entrar em contato com a solução de fosfato, os íons $\mathrm{PO}_{4}{ }^{3-}$ se acumulam ao redor desse complexo e iniciam a nucleação de HAp. Devido à forte interação química entres as carbonilas e os íons de $\mathrm{Ca}^{2+}$, a fibroína de seda induz a auto-organização e orientação dos cristais de HAp, tornando o seu crescimento espontâneo. Assim, HAp está fortemente reticulada com as fibras de FS, formando uma rede 3D por todo o biocompósito 


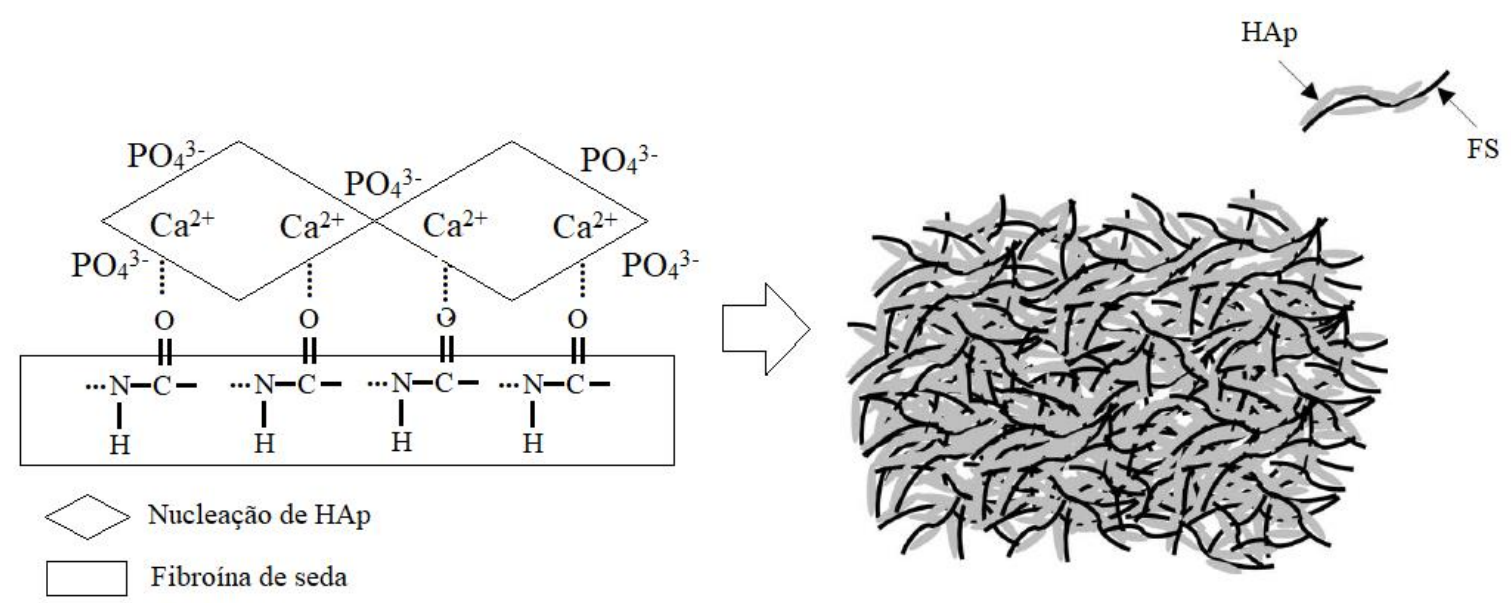

Fonte: Adaptado de Wang et al. (2004) e Fan et al. (2010)

Fan et al. (2010) e Zakharov et al. (2017) estudaram a fabricação de compósitos de fibroína de seda e hidroxiapatita através do processo de coprecipitação. Em seus estudos foi possível notar a integração e aglomeração entre fibroína de seda e hidroxiapatita, observação feita também em outros estudos que envolvem esses componentes, como o de Wang e Li (2007).

Gholipourmalekabadi et al. (2015) e Wang, Nemoto e Senna (2004) notaram que o aumento da \% de FS torna os poros condensados e compactados em orifícios menores. Em seus estudos concluiu-se que a densidade aumenta conforme acrescenta-se o polímero, devido a ligação entre as partículas de hidroxiapatita aglomeradas e as fibrilas da proteína da seda.

O composto estudado no presente trabalho apresenta boa reticulação das fibras de FS e HAp, sendo possível notar uma distribuição homogênea no suporte formado. O tamanho de poros está abaixo do determinado pela literatura para o desenvolvimento do novo tecido (acima de $100 \mu \mathrm{m}$ ), porém, somente os estudos in vivo poderão afirmar se haverá ou não crescimento ósseo através do material implantado.

\subsection{Porosidade e absorção de líquidos}

A porosidade dos suportes 3D é uma característica importante para avaliar as propriedades do biomaterial na engenharia de tecidos. Geralmente, autores sugerem que esta propriedade tem a necessidade de ser maior que $30 \%$ para, assim, permitir a interconexão e providenciar oportunidades suficientes para a migração e expansão celular. Os poros auxiliam no transporte de nutrientes e oxigênio para o interior dos scaffolds. Dessa maneira, células 
podem, então, se movimentar através dos poros e se aderirem em posições ideais para sua proliferação (LIN et al., 2008; PARK et al., 2015; TEIMOURI et al., 2015).

A capacidade de absorção de líquidos dos scaffolds é um importante fator a ser analisado também, pois, vai permitir que os nutrientes penetrem por todo o material implantado, facilitando a infiltração e a proliferação de células. Tem a capacidade de maximizar a área superficial interna dos suportes, pois, aumenta a porosidade total e o tamanho de seu poro. Os materiais que apresentam alta capacidade de absorção de líquidos tendem a possuir maior probabilidade de difusão das células, como também, seus crescimentos e adesões (PARK et al., 2015; TEIMORI et al., 2015).

A porosidade e a absorção de álcool do composto $75 \% \mathrm{HAP}+25 \% \mathrm{FS}$ estão descritos na Tabela 8. O líquido escolhido para realizar esse ensaio foi álcool, pois tende a não entumecer ou desidratar o material, sendo possível um resultado mais apurado. As amostras prensadas a 50 e 100 MPa não apresentaram grandes diferenças na porosidade média, porém, as amostras prensadas a $100 \mathrm{MPa}$ apresentam uma absorção de líquidos aproximadamente 5\% mais elevada do que as prensadas a $50 \mathrm{MPa}$. Ambas as amostras apresentaram estrutura propícia para adesão e crescimento celular, com porosidade acima de $50 \%$.

Tabela 8 - Porosidade e absorção de líquido do composto 75\%HAP + 25\%FS prensados a 50 e $100 \mathrm{MPa}$

\begin{tabular}{|c|c|c|}
\hline $\begin{array}{c}\text { Amostra } \\
(75 \% \text { HAp/25\% FS) }\end{array}$ & $\begin{array}{l}\text { Porosidade média } \\
\qquad(\%)\end{array}$ & $\begin{array}{c}\text { Absorção de álcool } \\
\text { média (\%) }\end{array}$ \\
\hline $50 \mathrm{MPa}$ & $52 \pm 2$ & $34 \pm 2$ \\
\hline $100 \mathrm{MPa}$ & $56 \pm 2$ & $40 \pm 5$ \\
\hline
\end{tabular}

Fonte: Elaborado pela autora

Diferentes trabalhos envolvendo os mesmos compostos são observados na literatura. Park et al. (2015), por exemplo, relataram em seus estudos uma porosidade acima de $65 \%$ e absorção de líquido acima de 83\%. Em outro estudo realizado por Lin et al. (2008), os scaffolds apresentaram porosidade acima de $40 \%$. Ambos estudos relatam que quanto maior a quantidade de HAp, maior a porosidade. Já a capacidade de absorção de líquidos diminui com o aumento de FS acrescentada, devido ao aumento da densidade do suporte. A porosidade do biocompósitos do presente projeto está de acordo com a esperada para materiais para substitutos ósseos. 


\subsection{Microtomografia computadorizada $(\mu-\mathrm{CT})$}

A microtomografia computadorizada é uma técnica utilizada para avaliar a porosidade interconectada do material. Nas Figuras 15 e 16 é possível observar as imagens 3D obtidas através da $\mu \mathrm{CT}$ para as amostras prensadas à 50 e $100 \mathrm{MPa}$ do biocompósito $75 \%$ HAp $+25 \%$ FS. Observa-se uma porosidade homogênea no centro das amostras, obtendo uma região mais densa nas extremidades devido a prensagem.

Após análise visual, utilizou-se o software CTAN para cálculo de porosidade, tamanho de poros e distribuição. Foi selecionada uma região de interesse (ROI) para realização da análise (somente poros acima de $35 \mu \mathrm{m}$ podem ser detectados com a resolução do equipamento).

Figura 15 - Imagens de $\mu \mathrm{CT}$ das amostras prensadas à $50 \mathrm{MPa}$
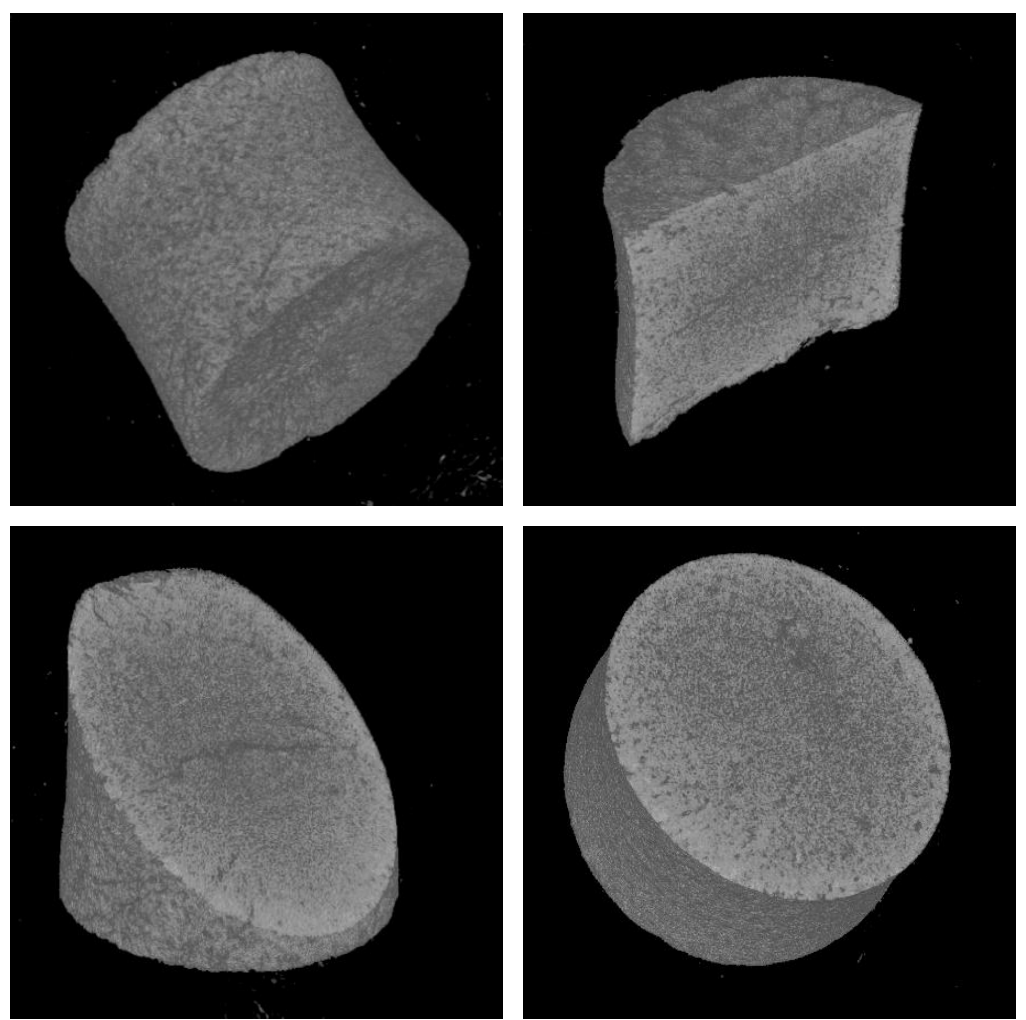

Fonte: Elaborado pela autora 
Figura 16 - Imagens de $\mu \mathrm{CT}$ das amostras prensadas à $100 \mathrm{MPa}$
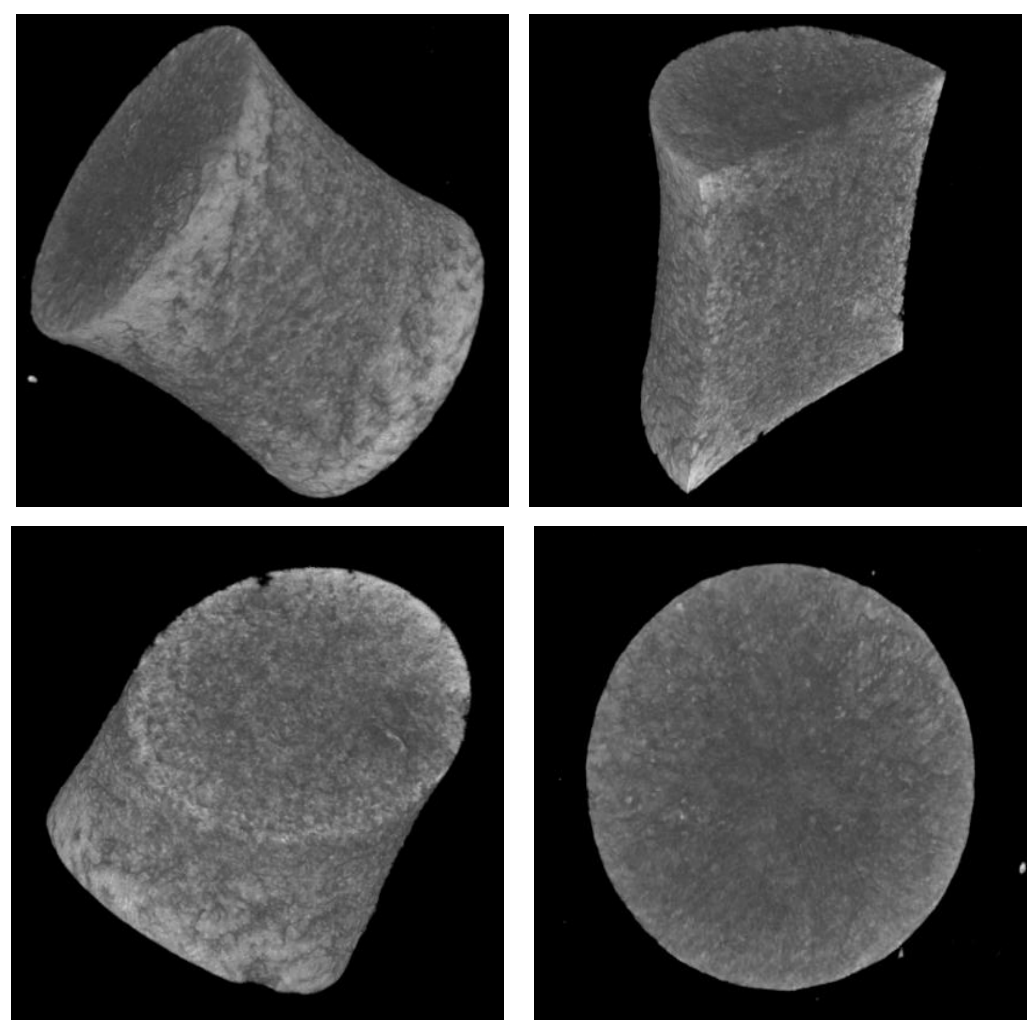

Fonte: Elaborado pela autora

A porosidade encontrada para as amostras prensadas a 50 e $100 \mathrm{MPa}$ são apresentadas na Tabela 9.

Tabela 9 - Resultados obtidos pela análise CTAN

\begin{tabular}{c|c|c}
\hline Amostras & $\mathbf{5 0} \mathbf{~ M P a}$ & $\mathbf{1 0 0} \mathbf{~ M P a}$ \\
(75\%HAp/25\%FS) & & \\
Volume total (mm3) & 404,12 & 570,45 \\
Volume preenchido (mm3) & 368,19 & 542,32 \\
Porcentagem de porosidade (\%) & 8,89 & 4,93 \\
\hline
\end{tabular}

Fonte: Elaborado pela autora

Para as imagens prensadas a $50 \mathrm{MPa}$, aproximadamente $9 \%$ dos poros são acima de $35 \mu \mathrm{m}$. Já para as amostras prensadas a $100 \mathrm{MPa}, 5 \%$ são poros acima de $35 \mu \mathrm{m}$. Os dados gerados estão de acordo com as análises realizadas por MEV, onde se avaliou que a grande maioria dos poros são menores que $35 \mu \mathrm{m}$, não ultrapassando $50 \mu \mathrm{m}$, porém, esse tamanho permite a difusão de osteócitos, osteoclastos e o crescimento de vasos sanguíneos. 


\section{5 Área superficial (BET)}

Um grande desafio no desenvolvimento de materiais porosos é sintetizar estruturas químicas similares com o osso e com alta área superficial. A hidroxiapatita do tecido ósseo possuí baixa estabilidade, boa solubilidade e alta reatividade. Essas características estão diretamente ligadas a morfologia de suas partículas, sendo essas de tamanho pequeno, apresentando baixa cristalinidade e alta área superficial (PADILLA; IZQUIERDO-BARBA; VALLET-REGÍ, 2008).

Combinada com as demais características morfológicas, tais como porosidade, interconexão e diâmetro do poro, a área superficial do material é uma grande aliada para promover o crescimento ósseo. Uma de suas vantagens é melhorar a interface, a adesão e a fixação entre o implante e o tecido hospedeiro. Há muitos fatores que influenciam na área superficial da hidroxiapatita, tais como, tamanho de partícula, processo de síntese, tratamentos térmicos, entre outros. (SEPULVEDA et al., 2000) (CHOI et al., 2006).

A área superficial de amostras macroscópicas de pós e materiais porosos é normalmente determinada pela medida de gás absorvido através da amostra, e, calculado utilizando isotermas de Brunauer-Emmett-Teller (BET). A área superficial do composto estudado $(75 \% \mathrm{HAp}+25 \% \mathrm{FS})$ foi medida utilizando absorção de nitrogênio e o valor encontrado foi de 20,61 $\mathrm{m}^{2} / \mathrm{g}$, dentro do esperado para a hidroxiapatita processada pela metodologia de precipitação (menor que $100 \mathrm{~m}^{2} / \mathrm{g}$ ).

Baseado em estudos de materiais in vivo, o tamanho das partículas demonstra ter um papel importante na resposta do tecido hospedeiro. Materiais metálicos e poliméricos no estado bulk, inseridos em tecido muscular ou ósseo, resultam em formação de membrana fibrosa. Em contraste, materiais em pó resultam em reação inflamatórias. Em estudos prévios, já se sabe que as características físicas das partículas de hidroxiapatita têm influenciado nas respostas inflamatórias. (GELB et al., 1994).

Evans (1990) analisou o efeito de três classes de tamanho de partículas de hidroxiapatita em fibroblastos (grande $>99 \mu \mathrm{m}$, média $>3,9 \mu \mathrm{m}$ e pequena $<3,9 \mu \mathrm{m}$ ). Em seu estudo foi possível identificar interferências somente em partículas consideradas pequenas. Essas reduziram a taxa de crescimento e proliferação celular, enquanto que aumentaram o número de células tóxicas, causadoras de apoptose.

Laquerriere et al. (2003) também analisaram a influência da morfologia das partículas de hidroxiapatita em respostas inflamatórias. Em seu estudo, in vitro, o tamanho (1-300 $\mu \mathrm{m})$, 
a forma (esfera, agulha e irregular) e a área superficial $\left(0,5-40 \mathrm{~m}^{2} / \mathrm{g}\right)$ foram avaliadas. Além disso, demonstrou que a produção de células tóxicas pode ser influenciada pelas características físicas, principalmente pela forma (agulha) e tamanho (1-30 $\mu \mathrm{m})$.

\subsection{Análise da relação Ca/P (EDS)}

O espectro mostrado na Figura 17 foi obtido através da análise de dispersão de energia de raios-X, uma técnica em que se avalia a composição química através de picos característicos da estrutura atômica dos átomos. Na tabela 10 encontram-se as porcentagens dos elementos químicos presentes no composto estudado e na hidroxiapatita padrão $\left(\mathrm{Ca}_{10}\left(\mathrm{PO}_{4}\right)_{6}(\mathrm{OH})_{2}\right)$. Nota-se que a relação $\mathrm{Ca} / \mathrm{P}$ está dentro do desejado, sendo essa de 1,67. Também se observam picos referentes aos elementos $\mathrm{C}$ e $\mathrm{O}$, no biocompósito, evidenciam a presença da fibroína de seda (ZAKHAROV et al., 2017).

Figura 17 - Espectro EDS do biocompósito (-) 75\%HAP + 25\% FS.

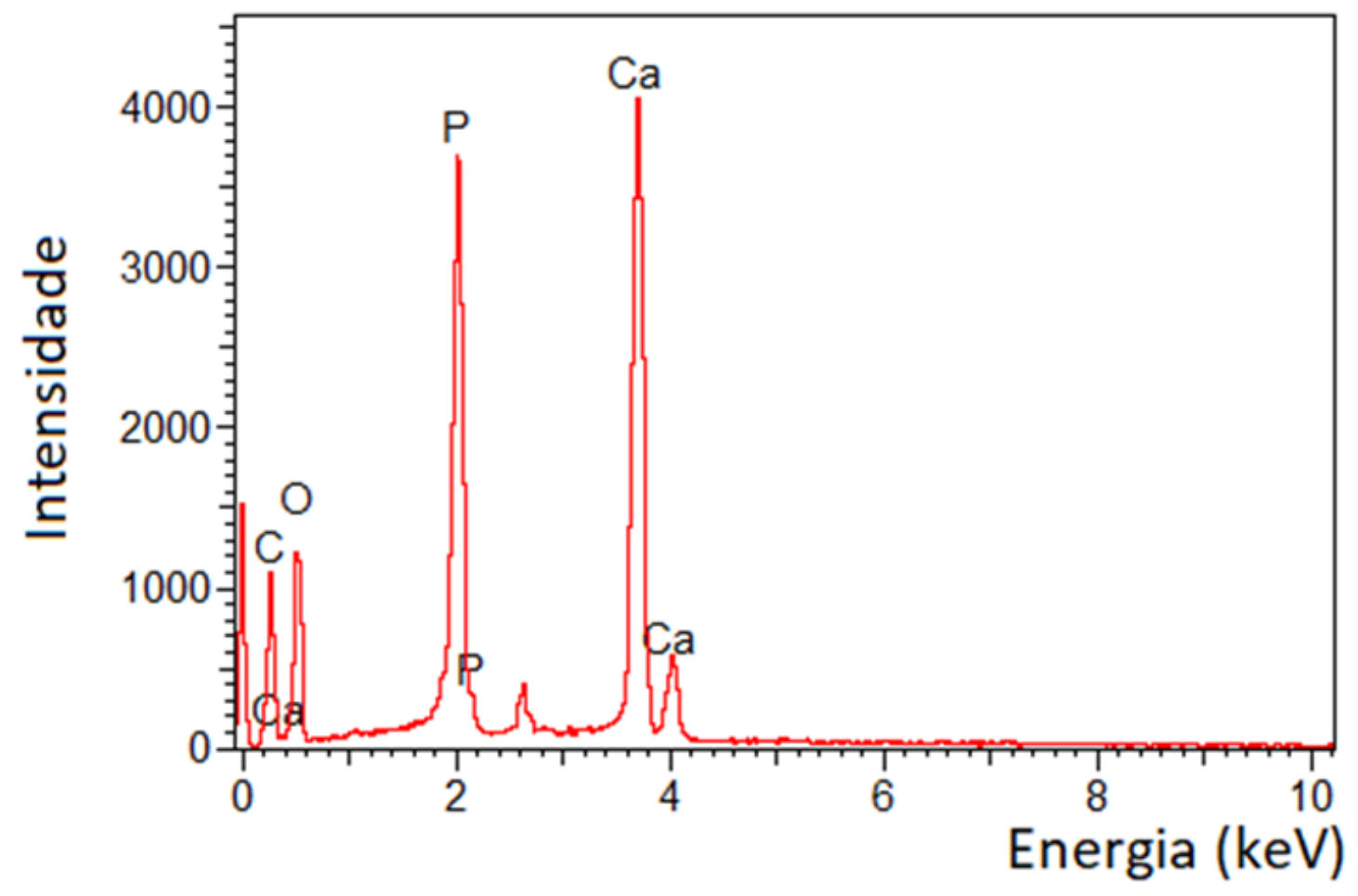

Fonte: Elaborado pela autora 
Tabela 10 - \% dos elementos químicos presentes no biocompósito experimental e na hidroxiapatita teórica

\begin{tabular}{ccc}
\hline Elemento & Experimental (\%) & Teórico*(\%) \\
\hline $\mathrm{C}$ & 27,27 & 0 \\
$\mathrm{O}$ & 39,73 & 59,09 \\
$\mathrm{P}$ & 12,39 & 13,64 \\
$\mathrm{Ca}$ & 20,61 & 22,73 \\
$\mathrm{H}$ & $\mathrm{N} / \mathrm{A}$ & 4,54 \\
$\mathrm{Ca} / \mathrm{P}$ & 1,67 & 1,67 \\
\hline
\end{tabular}

*Fonte: Adaptado de Du et al. (2009)

Nos trabalhos de Du et al. (2009) e Fan et al. (2010), ambos processaram compósitos de fibroína de seda e hidroxiapatita por coprecipitação, e obtiveram a relação $\mathrm{Ca} / \mathrm{P}$ próximas a 1,60 e 1,66, respectivamente. O composto estudo no presente projeto apresenta relação $\mathrm{Ca} / \mathrm{P}$ de 1,67, igual a esperada no valor teórico.

\subsection{Análise termogravimétrica (ATG)}

As curvas termogravimétricas da FS e do composto estudado HAp/FS estão mostradas na Figura 18. A primeira etapa, entre $25^{\circ} \mathrm{C}$ e $120^{\circ} \mathrm{C}$ é devido a perda de água do material. A segunda etapa, entre $300{ }^{\circ} \mathrm{C}$ e $600{ }^{\circ} \mathrm{C}$, representa a degradação térmica do componente orgânico. Para FS pura, essa inicia-se por volta de $290{ }^{\circ} \mathrm{C}$, enquanto que no biocompósito ela se acentua por volta de $300{ }^{\circ} \mathrm{C}$. Nota-se que não há mudança de massa após $600{ }^{\circ} \mathrm{C}$, indicando que todo o polímero foi degradado. A perda total de massa do composto foi de $35 \%$, sendo $5 \%$ referente a perda de $\mathrm{H}_{2} \mathrm{O}$. Entretanto, a composição Orgânico/Inorgânica é de aproximadamente 30/70, muito próxima à planejada de 25/75.

Liu et al., (2008) estudaram o comportamento térmico de scaffolds de HAp + FS processados por liofilização e relataram grande perda de massa entre 50-700 ${ }^{\circ} \mathrm{C}$. A primeira perda notável foi abaixo de $120^{\circ} \mathrm{C}$, devido a eliminação de água. A degradação térmica da fibroína de seda ocorreu por volta de $310-315^{\circ} \mathrm{C}$, sugerindo que as proteínas da FS possuem boa orientação molecular e alta cristalinidade, pois em sua estrutura amorfa, normalmente essa degradação ocorre por volta de $280{ }^{\circ} \mathrm{C}$ (ZHANG et al., 2002).

Em outro estudo com filmes do mesmo compósito os resultados foram semelhantes. Du 
et al. (2009) também relacionaram as temperaturas de degradação térmica ao comportamento cristalino da fibroína de seda. Alguns filmes com baixa \%HAp apresentaram decomposição térmica do polímero por volta de $289^{\circ} \mathrm{C}$, indicando que há estrutura amorfa remanescente. Nos filmes em que a \% de HAp é aumentada, essa temperatura aumenta para $315^{\circ} \mathrm{C}$.

O comportamento térmico de compósitos formados a partir do processo de coprecipitação, com solução ternária sem diálise, foi relatado no trabalho de Fan et al. (2010). Mais uma vez se tem a mesma observação em relação à ligação do polímero com a cerâmica. Em seus estudos, a degradação da fibroína de seda inicia-se por volta de $360{ }^{\circ} \mathrm{C}$, maior do que a esperada, por volta de $290{ }^{\circ} \mathrm{C}$, indicando que a há uma forte ligação entre HAp e FS, uma boa orientação molecular e a alta cristalinidade do polímero.

Figura 18 - Curva termogravimétrica (-) TGA (-) DTG (A) Biocompósito 75\%HAp/25\%FS (B) Fibroína de seda

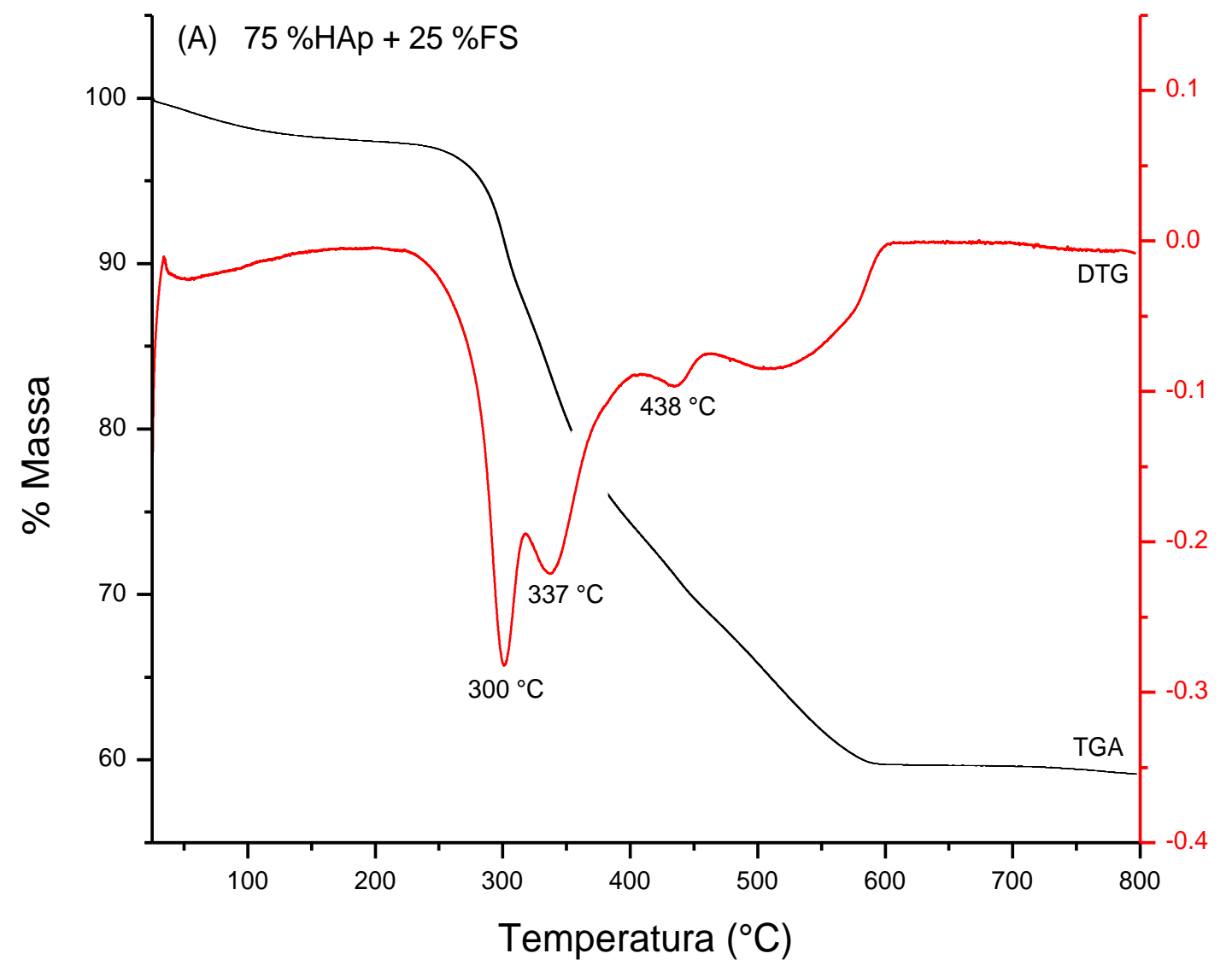




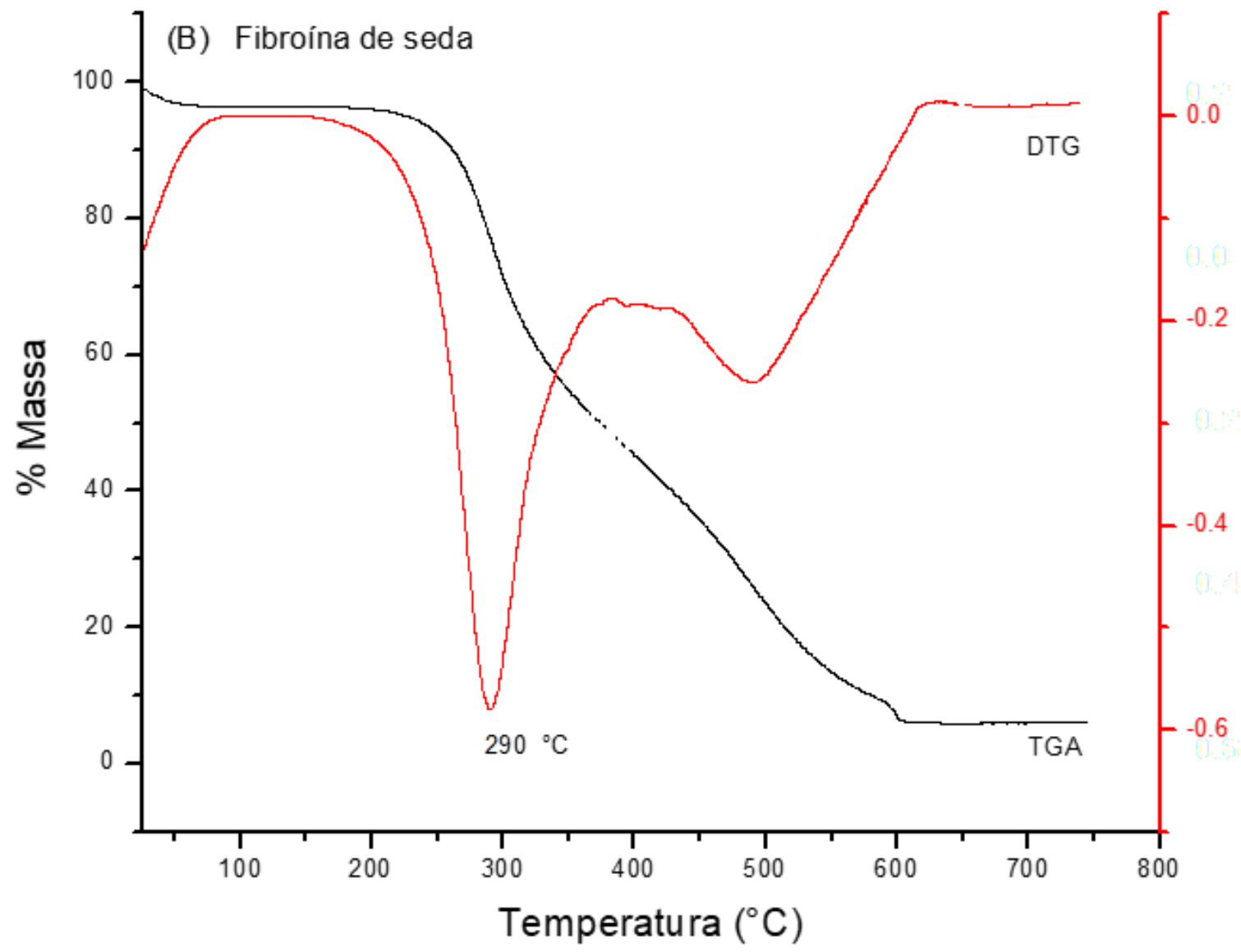

Fonte: Elaborado pela autora

\subsection{Espectroscopia na região do infravermelho (FTIR)}

A espectroscopia na região do infravermelho (FTIR) é uma ótima ferramenta para análise estrutural devido ao conhecimento das vibrações dos grupos funcionais do material. Na Figura 19 é possível observar os espectros do biocompósito estudado, da fibroína de seda pura e da hidroxiapatita do fêmur bovino (desproteinizado no grupo de bioquímica e biomateriais do IQSC- USP).

No espectro referente ao composto HAp+FS da Figura 19(A), as bandas de absorção de 1098, 1041, 844, 601 e $568 \mathrm{~cm}^{-1}$ são referentes aos íons $\mathrm{PO}_{4}{ }^{-3}$ da hidroxiapatita, as mesmas bandas também são identificadas no espectro (C) da HAp do fêmur bovino desproteinizado. Essas bandas estão associadas às vibrações das ligações dos íons fosfatos. A banda próxima a $1041 \mathrm{~cm}^{-1}$ é referente aos estiramentos de ligações de P-O, e as bandas em 601 e $568 \mathrm{~cm}^{-1}$ indicam deformações das ligações P-O (KMITA et al., 2005) (ŚLÓSARCZYK, et al., 2005) (MOBASHERPOUR, et al., 2007). Baseado no espectro do biocompósito estudado, concluise que não ocorreram mudanças significativas nas formas e intensidades das bandas características para hidroxiapatita. 
As bandas (espectro B) 1658, 1532 e $1368 \mathrm{~cm}^{-1}$ são características das vibrações dos grupos amida I, II e III, respectivamente, presentes na fibroína de seda. É possível notar que essas bandas apresentam picos mais intensos no biocompósito (75\%HAp+25\%FS) do que na fibroína pura, indicando que há um aumento da conformação folha- $\beta$ (CHEN et al., 2001; HOFMANN et al., 2006; NAZAROV; JIN; KAPLAN, 2004). Esses resultados mostraram que não ocorreram mudanças no padrão das ligações químicas dos precursores do biocompósito, ou seja, não ocorreu formação ou interações novas durante o processamento do mesmo.

Figura 19 - Espectroscopia de absorção no infravermelho de: A (一) biocompósito 75\%HAp/25\%FS; B (一) Fibroína de seda; C (-) HAP de fêmur bovino desproteinizado.

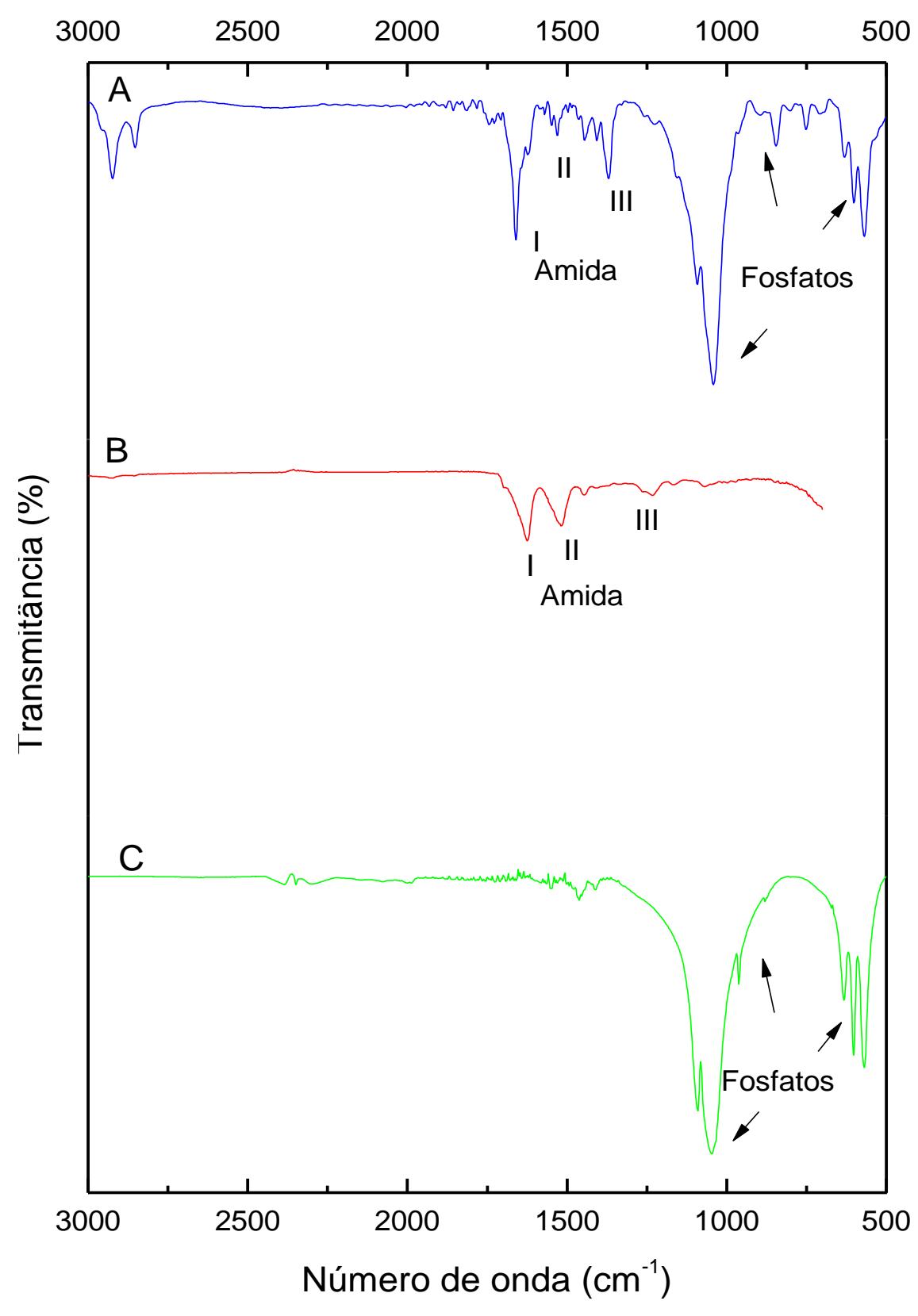

Fonte: Elaborado pela autora 


\subsection{Difratometria de Raios-X (DRX)}

A determinação da estrutura cristalina de um novo material é pré-requisito para o bom entendimento de suas propriedades no estado sólido. A técnica de difração de Raio-X (DRX) é utilizada para determinar o padrão de cristalinidade dos materiais (BRUNDAVANAM; POINERN; FAWCETT, 2013). Na Figura 20 observa-se o espectro padrão de difração de raio-X para o biocompósito $75 \% \mathrm{HAp}+25 \mathrm{FS}$. A identificação das fases foi comparada com o espectro para hidroxiapatita presente no documento A.S.T.M. No. 9-432 - ICDD - The International Centre of Diffraction Data - Powder diffraction.

O composto estudado apresenta linhas de difração características de hidroxiapatita, não sendo identificado presença de outros fosfatos de cálcio. Os planos cristalográficos encontrados, sendo (002), (211), (310), (222), (213) e (004) comprovam esse fato. Entretanto, a ampliação e a sobreposição de picos (evidenciado no plano 211) demonstra a presença de fase amorfa na hidroxiapatita precipitada (KOUTSOPOULOS, 2002; BRUNDAVANAM; POINERN; FAWCETT, 2013). Os resultados encontrados no espectro de DRX estão de acordo com os presentes no espectro FTIR e EDS, dessa maneira, afirma-se que houve a precipitação de hidroxiapatita com a metodologia estudada.

Figura 20 - Difração de Raio-X padrão (一) biocompósito 75\%HAp/25\%FS

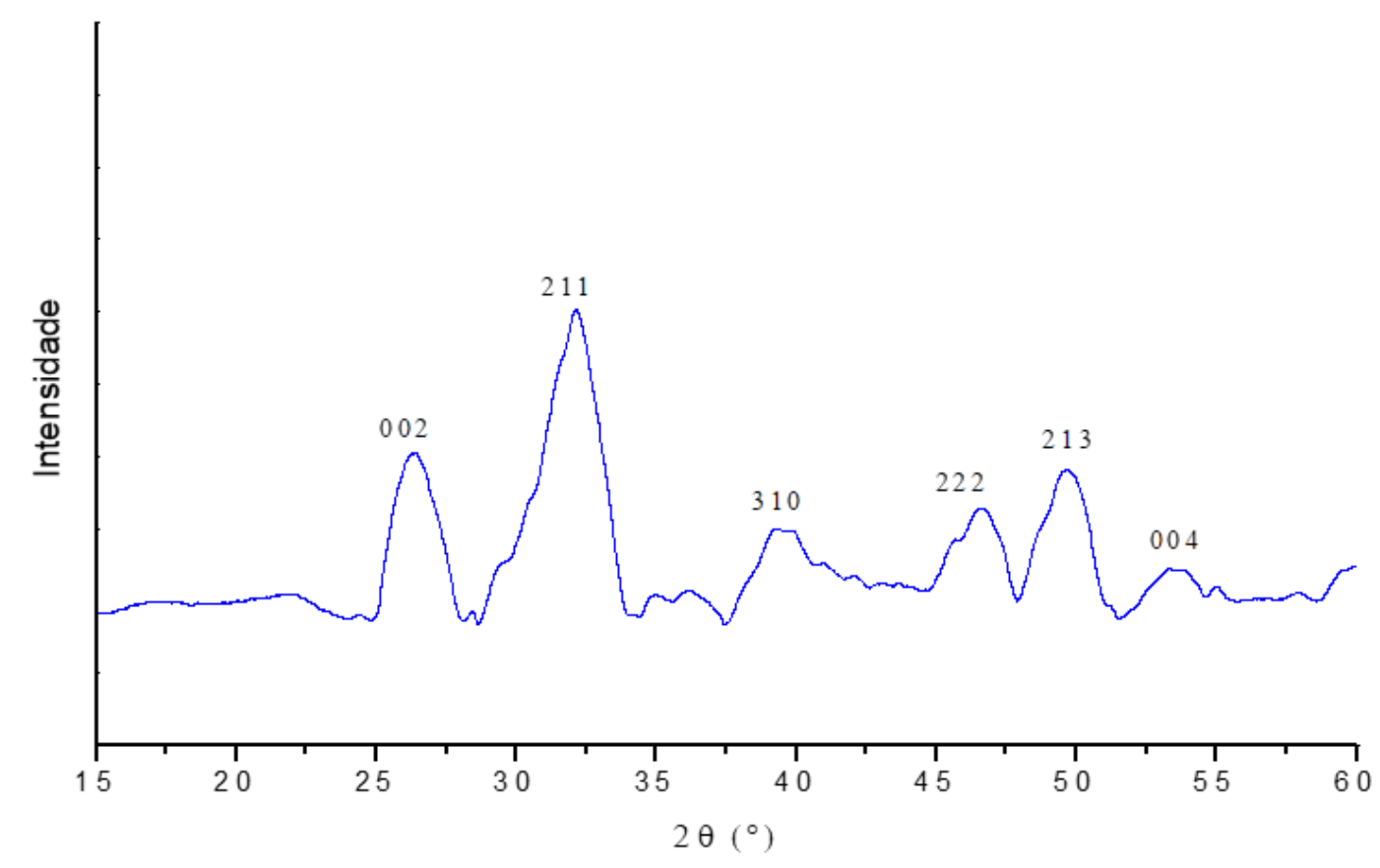

Fonte: Elaborado pela autora

Pang e Bao (2003) analisaram a influência da temperatura na cristalinidade de hidroxiapatita sintética. A baixas temperatura (entre $15-70{ }^{\circ} \mathrm{C}$ ) observa-se a ampliação e 
sobreposição dos picos, enfatizando sua fase amorfa. Foi noticiado que com o aumento da temperatura, esses picos se tornam agudos, indicando o aumento da cristalinidade. Porém, o aumento da fase cristalina só é observado em temperaturas acima de $70{ }^{\circ} \mathrm{C}$, abaixo dessa temperatura, os cristais de HAp são monocristalinos, enquanto que acima se tornam multicristalinos, explicando a mudança estrutural.

Os mesmos resultados foram obtidos em diferentes estudos de compósitos formados a partir de HAp e FS. Fan et al. (2010), Liu et al. (2008), Murugan e Ramakrishna (2004) e Wang, Nemoto e Senna (2004) observaram os mesmos picos amplificados e sobrepostos no plano cristalográfico (211), resultando em baixa cristalinidade e maior presença amorfa quando comparada com outras hidroxiapatitas sintéticas. Todos os estudos atrelam esses resultados aos processos de fabricação, evidenciando que a temperatura tem grande influência na formação de cristais. Apesar de seus resultados não estarem de acordo com HAp comercializada, eles demonstram a formação de uma fase inorgânica muito similar a apatita biológica presente no osso natural.

\subsection{Resistência à compressão}

Um dos grandes desafios no desenvolvimento de suporte de cargas na engenharia de tecido ósseo é atrelar a porosidade com a resistência mecânica. Uma estrutura com a porosidade ideal muitas vezes sacrifica as propriedades mecânicas. Não se sabe ao certo as propriedades mecânicas ideais, mas, busca-se um material mais próximo possível à resistência do osso que será substituído. Os ensaios de compressão mecânica foram realizados para avaliar o comportamento do biocompósito estudado. As resistências à compressão mecânica do biocompósito $75 \% \mathrm{HAp}+25 \% \mathrm{FS}$ prensados manualmente, a $50 \mathrm{MPa}$ e a $100 \mathrm{MPa}$ podem ser observadas na Figura 21. 
Figura 21 - Resistência à compressão mecânica do biocompósito 75\%HAP + 25\%FS

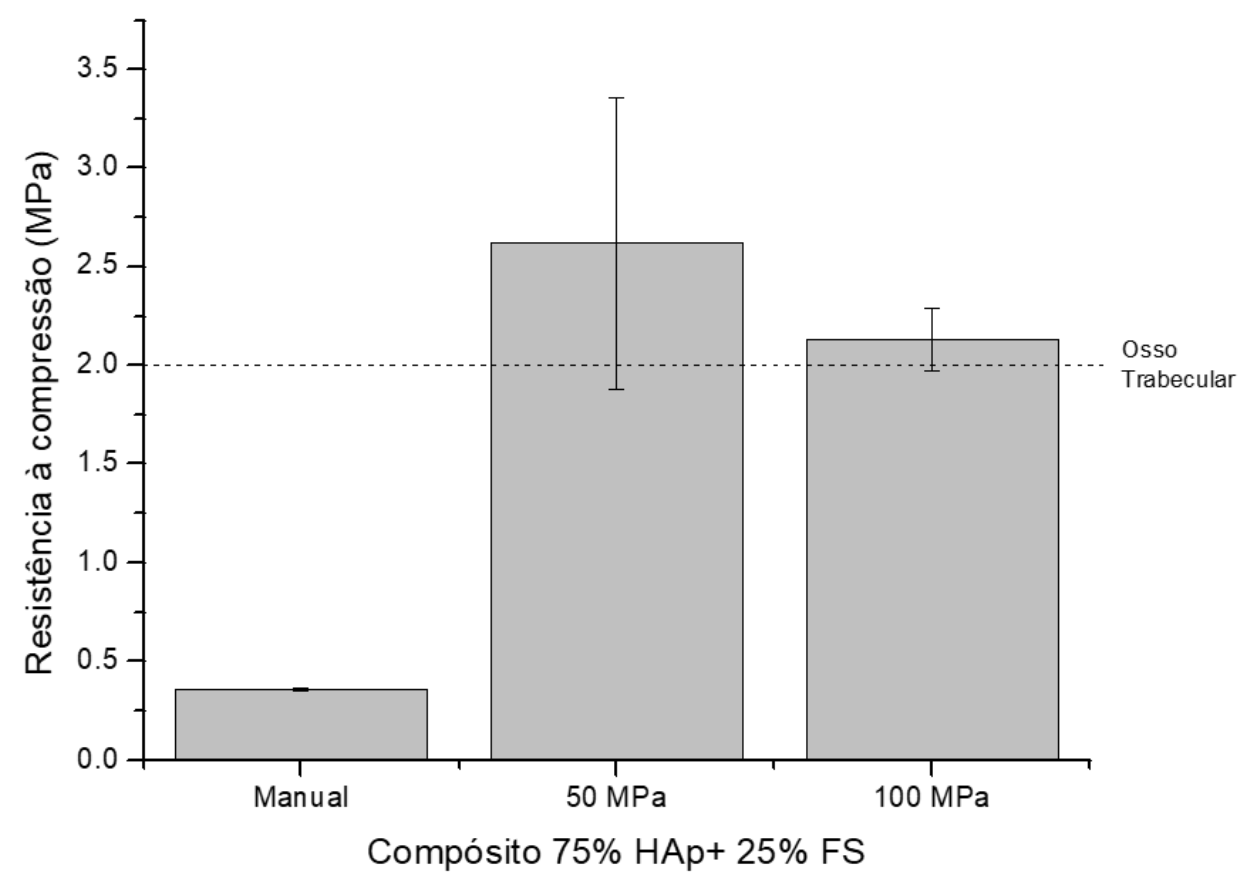

Fonte: Elaborado pela autora

Os scaffolds prensados a 50 e 100 MPa apresentaram resistências mecânicas próximas, sendo de 2,62 \pm 0,74 MPa e 2,13 $\pm 0,16 \mathrm{MPa}$, respectivamente, demonstrando ser comparável com as características do osso trabecular. Como esperado, apresentam uma resistência muito superior ao composto prensado manualmente de 0,360 $\pm 0,005 \mathrm{MPa}$. A resistência à compressão demonstra-se suficiente para garantir a estabilização pós-implante dos scaffolds, quando esses necessitam suportar as primeiras forças compressivas.

Esperava-se que as pressões de compactação gerassem diferenças consideráveis nas resistências à compressão entre as amostras conformadas a $50 \mathrm{MPa}$ e $100 \mathrm{MPa}$, porém isso não foi observado. A semelhança dessas resistências pode ser explicada devido à presença de laminação nas amostras. A laminação é um defeito caracterizado por trincas horizontais nos corpos prensados que ocorre quando a pressão de compactação é excessivamente alta (GLASS; EWSUK, 1997). Nas imagens da Figura 22, obtidas através da microtomografia computadorizada, é possível observar a presença do defeito. 
Figura 22 - Evidências de presença do defeito de laminação nas amostras prensadas
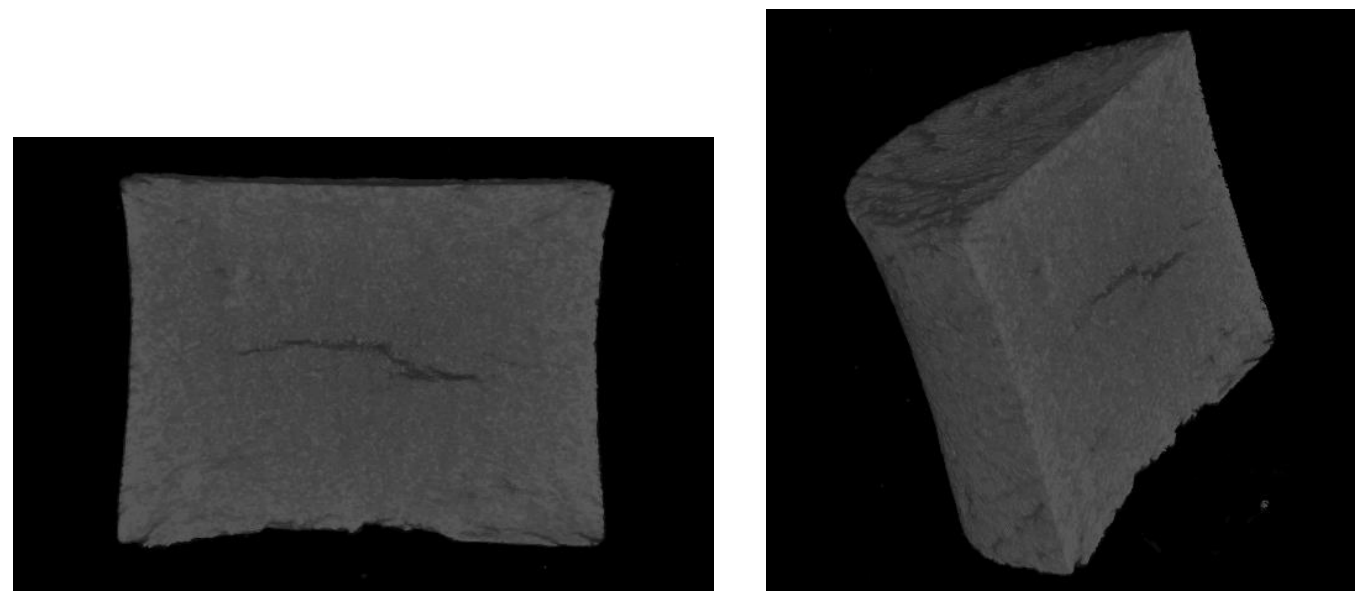

Fonte: Elaborada pela autora

Charrière, Lemaitre e Zysset (2003) estudaram o processamento de scaffolds macroporosos formados a partir de hidroxiapatita com porosidade de $56 \%$ com resistência à compressão de 12,5 \pm 4,6 MPa. Outro trabalho focado em scaffolds porosos de hidroxiapatita foi desenvolvido por Real et al. (2002), em seus estudos os suportes com porosidade de 51,8\% apresentaram resistência à compressão de 2,1 \pm 0,3 MPa. Já Landi et al. (2003) tiveram o mesmo objetivo, porém utilizando hidroxiapatita carbonatada, resultando em resistências de $6,0 \pm 0,5 \mathrm{MPa}$.

Gil et al. (2011) estudaram a resistência mecânica de scaffolds produzidos com fibroína de seda. A porosidade encontrada foi entre $92,7 \pm 0,9 \%$ e $74,6 \pm 0,9 \%$ e resistência á compressão entre de 0,47 $\pm 0,33 \mathrm{MPa}$ e 5,10 \pm 0,41 MPa. Concluiu-se em seu estudo que a resistência mecânica aumenta com o aumento de fibroína de seda adicionado

Muitos trabalhos foram desenvolvidos para compósitos com fibroína de seda junto a hidroxiapatita a fim de se produzir um material com porosidade e resistência ideais. No trabalho de Liu et al. (2008), as amostras com 70\%HAp+30\%FS exibiram resistência mecânica de 0,4 MPa e porosidade de $61,1 \% \pm 1,6$. Já Teimouri et al. (2015) produziram amostras com 70\% de HAp e 30\% FS com resistência de 0,9 MPa com porosidade de 50\%. Qi et al. (2014), desenvolveram compósitos com resistência à compressão de 4,5 MPa, com porosidade de $95 \%$.

\subsection{Bioatividade com solução de SBF}

Com o objetivo de investigar a capacidade de formação de apatita do material, as amostras foram submetidas a ensaio de bioatividade através de solução SBF (simulated body 
fluid).

Quando uma cerâmica bioativa é implantada, forma-se uma fina camada rica em Ca e P em sua superfície, denominada apatita. Esta, então, se conecta com o tecido vivo diretamente. A formação das camadas de apatita pode ser detectada por espectrometria de difração de raios-X (EDS) e/ou por microscopia eletrônica de varredura ASSOCIAÇÃO BRASILEIRA DE NORMAS TÉCNICAS, 2013; TEIMOURI et al., 2015).

A biomineralização de apatita na superfície de cerâmicas bioativas é considerado uma simulação da reação do material implantado com o plasma sanguíneo. Estudos in vitro com solução SBF possuem concentração iônicas próximas a esse fluído, mimetizando a formação de apatita em cerâmicas bioativas in vivo. Esse método pode ser utilizado com uma previsão antes de testes em animais, dessa maneira, otimizando o número de animais usados em estudos (KIM et al., 2004; KOKUBO; TAKADAMA, 2006).

As fotomicrografias das superfícies dos scaffolds do biocompósito estudado (Prensado a $50 \mathrm{MPa}$ ) antes e depois do ensaio SBF estão mostradas na Figura 23. As superfícies apresentam mudanças na morfologia entre a amostra sem SBF e as amostras com 2 e 4 semanas em SBF. Após duas semanas de ensaio já se nota a formação de apatita, comprovando que os scaffolds demonstraram alta habilidade em mineralizar em solução SBF na temperatura de $37^{\circ} \mathrm{C}$ e $\mathrm{pH} 7,4$.

Figura 23 - Fotomicrografias das amostras em ensaio SBF (A) 0 dias (B) 14 dias (C) 28 dias

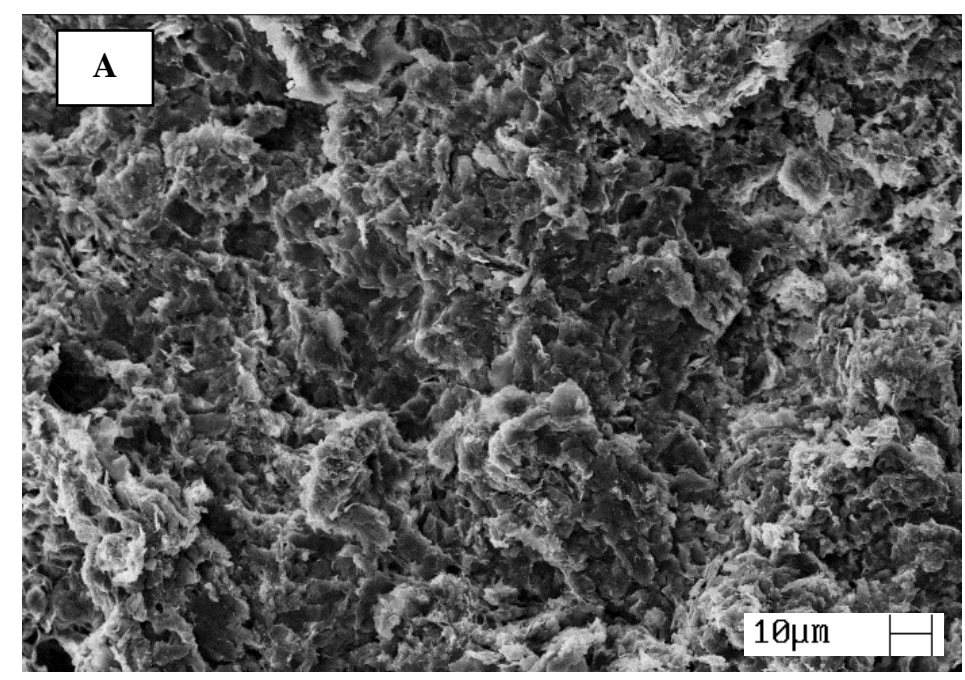



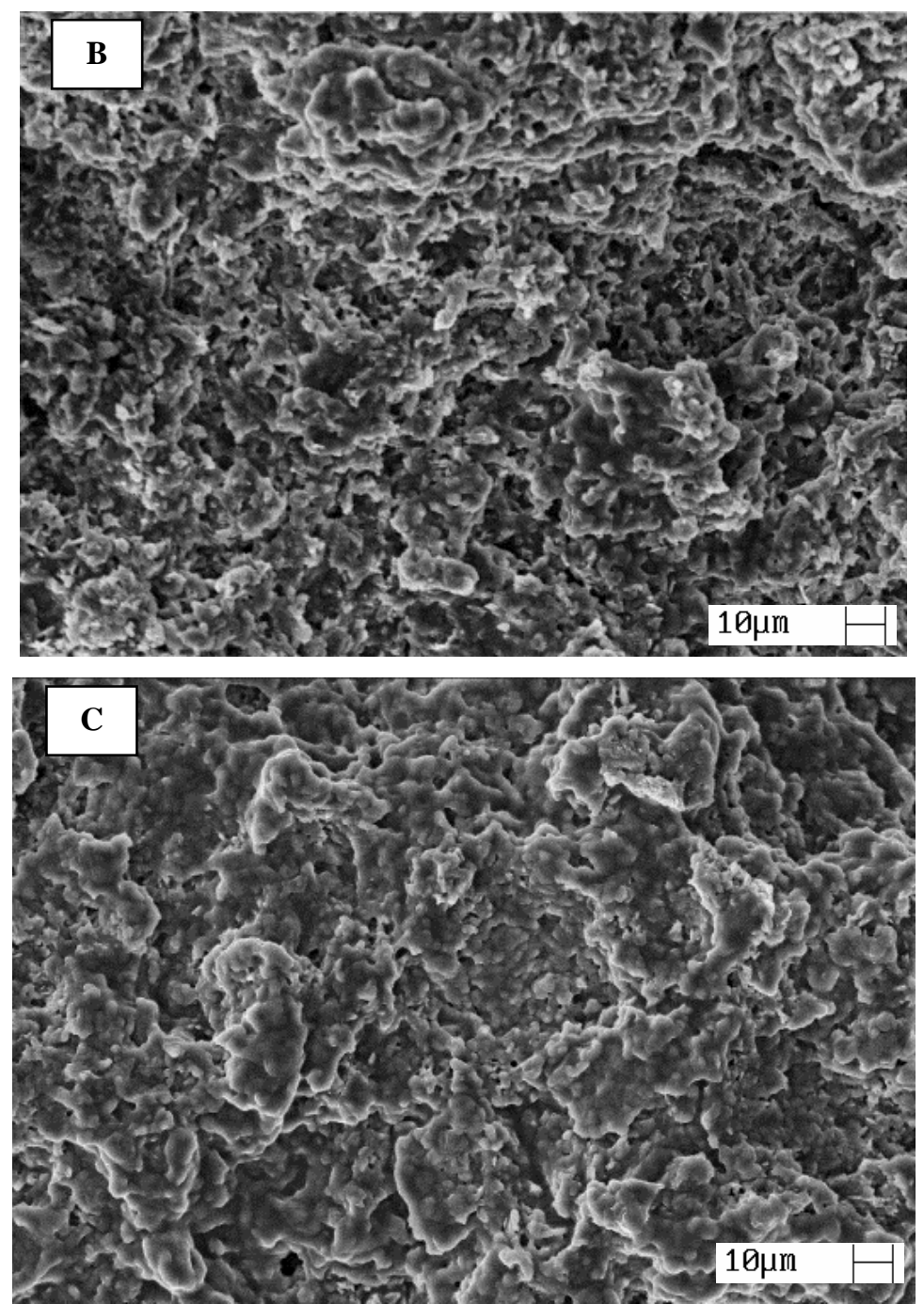

Fonte: Elaborado pela autora

A formação de apatita sob a superfície de hidroxiapatita sintética em solução de SBF foi estudada por Kim et al. (2004). Suas análises foram realizadas utilizando imagens geradas por microscópio eletrônico de transmissão (TEM) e EDX. A partir de 3h em contato com o fluído já é possível notar diferença na relação $\mathrm{Ca} / \mathrm{P}$ da superfície. Em $9 \mathrm{~h}$ de experimento, nota-se que a morfologia começa a alterar, sendo visível a formação de apatita, além de deposição de outros íons tais como, $\mathrm{Na}^{+}$e $\mathrm{Mg}^{+2}$, a partir desse tempo então, observa-se que a camada sob a hidroxiapatita só aumenta. Com seus estudos, comprovou-se a bioatividade da hidroxiapatita sintética, sendo que esta foi capaz de induzir a formação de apatita em meio SBF, assim como o biocompósito estudo no presente trabalho.

Teimouri et al. (2015) analisou a formação de apatita em scaffolds de HAp+FS, os quais demonstraram alta habilidade em mineralizar em meio SBF a $37{ }^{\circ} \mathrm{C}$. Após 14 dias de incubação as amostras foram avaliadas por $\mathrm{MEV}$, onde se detectou mudanças em sua morfologia. Em seu estudo concluiu que as amostras, contendo 
$70 \% \mathrm{HAp}+15 \% \mathrm{FS}+15 \%$ Gelatina, foram as que apresentaram mineralização com maior eficácia, demonstrando que o aumento da quantidade da cerâmica melhora a bioatividade do biocompósito. Esses estudos, assim como o presente trabalho, comprovam que a HAp sintética possui a capacidade de formação de apatita e auxilia na integração com o tecido hospedeiro. Além disso, a \% de HAp e FS do composto estudado demonstra-se como ideal para a melhor eficiência de formação de apatita.

A mudança observada na superfície da hidroxiapatita sintética ocorre devido interações eletrostáticas entre a mesma e os íons Ca e P presentes na solução SBF. O esquema pode ser notado na Figura 24. A HAp imersa em solução SBF possui cargas negativas, pois seu ponto isoelétrico (5-7) é menor que o $\mathrm{pH}$ da solução $(7,4)$. Dessa maneira, atrai os íons $\mathrm{Ca}^{+2}$ presentes no fluído formando uma camada com carga positiva, com isso, os íons de carga

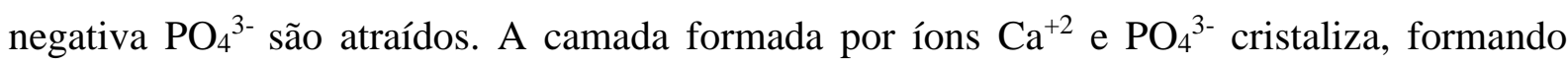
apatita estável sob a superfície de HAp, e dessa etapa em diante, mantém seu crescimento com o suplemento dos íons presentes na solução de SBF, incluindo sódio, magnésio e carbonatos, resultando em composição e estrutura semelhante ao osso mineral, conforme visto por Kim et al. (2004) e Teimouri et al. (2015).

Figura 24 - Esquema representativo da formação de apatita sob a camada de hidroxiapatita

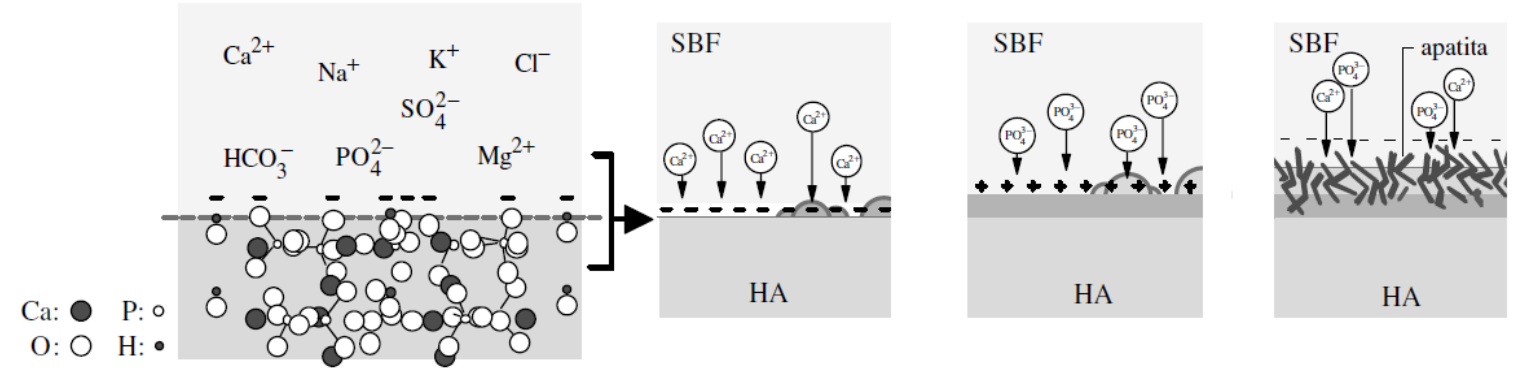

Fonte: Adaptado de Kim et al. (2004).

\subsection{Citotoxicidade por vermelho neutro}

O método de vermelho neutro é um dos mais utilizados para testes de citotoxicidade em aplicações biomédicas. Está baseado na habilidade de células vivas incorporarem-se e ligarem-se a coloração do reagente vermelho neutro. Essa coloração penetra nas células por difusão e se concentra nos lisossomos. A intensidade da cor é então extraída das células e a absorbância é obtida através de espectrofotômetro. Quando as células morrem ou o pH é alterado, não é possível observar essa coloração. Dessa maneira, a intensidade da cor do meio celular é indicativa da viabilidade celular (REPETTO; PESO; ZURITA, 2008)

O ensaio de citotoxicidade é o primeiro passo afim de comprovar a biocompatibilidade 
de um dispositivo médico. Um resultado negativo indica que o material está livre de elementos tóxicos ou possui em quantidade insuficiente para causar algum dano. Em contraste, um resultado positivo pode servir como um alerta que o material possui substâncias que podem ocasionar problemas ao corpo implantado. Em ambos os casos, há a necessidade de outros ensaios para se comprovar a total biocompatibilidade do material (WALLIN; ARSCOTT, 1998; ROGERO et al., 2003).

Na Figura 25 está apresentado o gráfico com as curvas da viabilidade celular do composto estudado, $75 \% \mathrm{HAp}+25 \% \mathrm{FS}$, prensado a 50 e $100 \mathrm{MPa}$. Neste gráfico pode-se verificar que todas as amostras de scaffolds testados apresentaram comportamento semelhante ao controle negativo (Alumina), ou seja, não mostraram toxicidade. Somente o controle positivo mostrou-se tóxico (Fenol), como era esperado, apresentando índice de citotoxicidade (IC50\%) abaixo de 70.

Figura 25 - Curvas de viabilidade celular: (-) Controle positivo (-) Controle negativo (-) 75\%HAp+25\%FS prensado $50 \mathrm{MPa}(-) 75 \% \mathrm{HAp}+25 \% \mathrm{FS}$ prensado $100 \mathrm{MPa}$

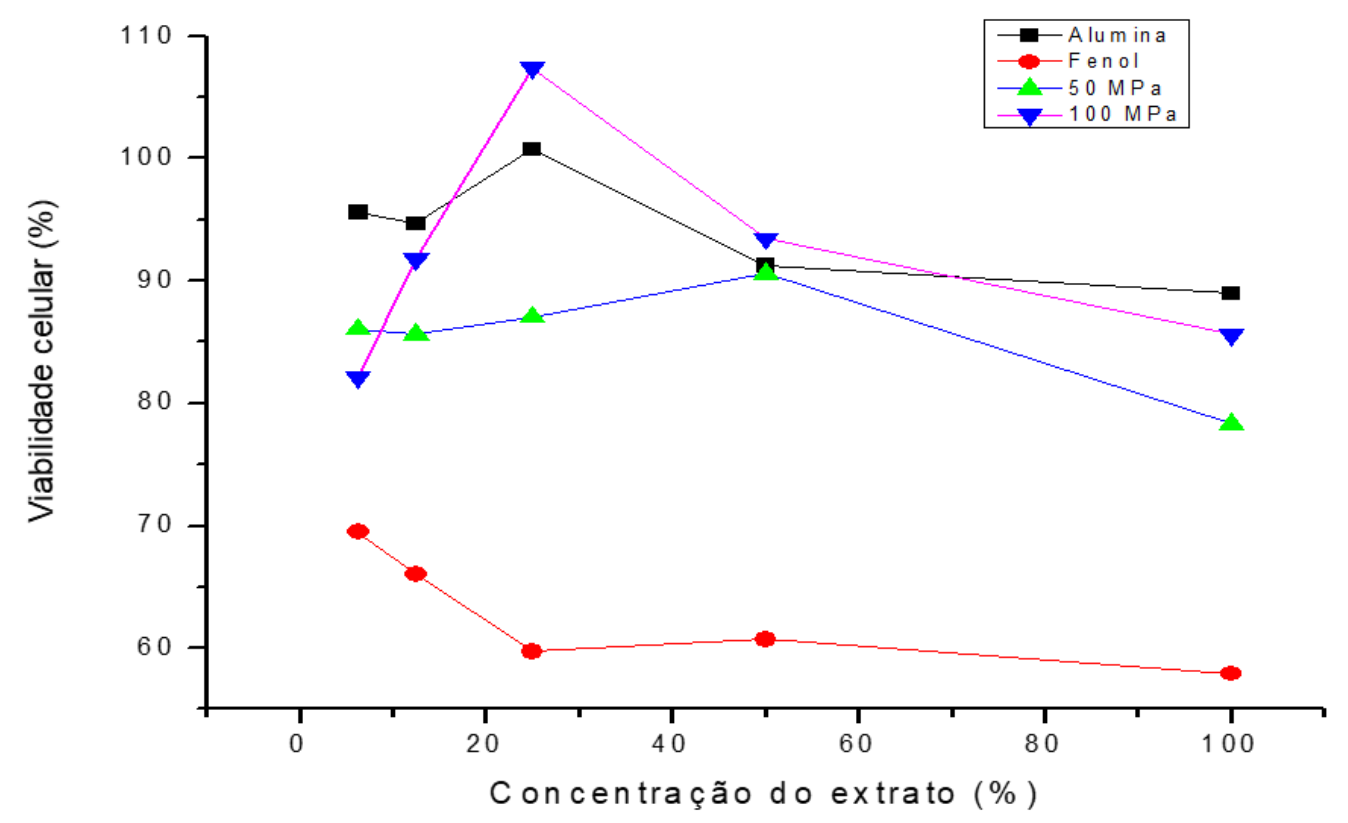

Fonte: Elaborado pela autora

O índice de citotoxicidade, IC50(\%), foi determinado como sendo a concentração do extrato do composto que inibe $50 \%$ da incorporação do vermelho neutro. O índice foi obtido correlacionando o percentual médio de células vivas com a concentração dos extratos. $\mathrm{O}$ controle positivo (Fenol) mostrou-se mais tóxico, apresentando IC (50\%) de 57. Os scaffolds obtidos, bem como o controle negativo, alumina, apresentaram percentuais de viabilidade celular boas, acima de $80 \%$. 


\section{CONCLUSÃO}

No presente estudo foi possível obter hidroxiapatita através do processo de coprecipitação junto à fibroína de seda. As análises químicas e estruturais comprovam que a junção de FS com HAp não alterou a estrutura dos compostos, mantendo suas funções desejadas. Além disso, a HAp sintética apresenta com estrutura menos cristalina, ótima para o processo de biodegradação.

Os blocos apresentam porosidade ideal para a adesão, proliferação celular e formação de vasos sanguíneos, além de boa capacidade de absorção de líquidos, demonstrando que estão interconectados. As fotomicrografias obtidas através de MEV e as imagens da microtomografia computadorizada comprovam a formação de poros e seus canais. A morfologia do composto se mostra como uma boa perspectiva para área de regeneração óssea.

O uso da fibroína de seda aumentou a resistência mecânica dos blocos, tornando-os materiais miméticos ao osso trabecular. A relação de matriz inorgânica/orgânica do biocompósito também se apresenta próxima ao futuro tecido hospedeiro. O biomaterial apresentou-se como bioativo, sendo comprovada a formação de camada de apatita após 28 dias de incubação em solução de SBF. Os testes preliminares de citotoxicidade sugerem um material biocompatível, sem causar danos às células.

Além de possuir características propícias a um substituto ósseo, a metodologia de fabricação do biocompósito (co-precipitação) é simples, rápida e não utiliza altas temperaturas para sua conformação, tornando o processo econômico e sustentável. O presente estudo é inédito na área de engenharia tecidual e apresenta grande potencial para futuras aplicações. 


\section{SUGESTÕES FUTURAS}

Para resultados conclusivos do biomaterial em questão, sugere-se que sejam realizados:

- Avaliação do comportamento do material com células ósseas (in vitro), avaliando a interação de osteoblastos e osteoclastos com o biocompósito;

- Avaliação in vivo, para estudar se há a necessidade de aumento dos poros para crescimento do novo tecido (ideal para tecido ósseo $>100 \mu \mathrm{m}$ );

- Caso haja necessidade, estudar um incremento de porosidade (além de açúcar cristalizado, sais de $\mathrm{NaCl}$ e amido de milho, pois todos foram testados no presente projeto e não apresentaram o efeito esperado);

- Uso da prensagem isostática nos blocos para processo de usinagem, focando na obtenção de parafusos de HAp e FS (resistente a torção para substituição dos parafusos metálicos). 


\section{BIBLIOGRAFIA}

AHADIAN, S. et al. Tissue engineering for artificial organs: regenerative medicine, smart diagnostics and personalized medicine. Boston: John Wiley \& Sons, 2017.

AJISAWA A. Studies on the dissolution of silk fibroin. The Journal of Sericultural Science of Japan, v. 38, p. 365-370, 1969.

ANDREAS S. et al. Controlling silk fibroin particle features for drug delivery. Biomaterials, v. 31, p. 4583-4591, 2010.

ASSOCIAÇÃO BRASILEIRA DE NORMAS TÉCNICAS. NBR ISO 23317: implantes para cirurgia: avaliação in vitro da capacidade de formação de apatita de materiais de implante. Rio de Janeiro, 2013.

BAJAJ, K. Global Biomaterial Market. Disponível em: https://www.picsnaper.com/p/Global-Biomaterial-Market-2009-to-2014-ppt-video-onlinedownload. Acesso em: 15 nov. 2018.

BICALHO, S. M. C. M., BORGES, A. P. B., REZENDE, C. F. HAP-91 ® casuística e estudos científicos. 4. ed. Belo Horizonte: Propartner. 2011.

BILEZIKIAN, J. P. et al. Principles of bone biology. 2. ed. San Diego: Academic Press, 2002.

BRUNDAVANAM, R. K.; POINERN, G. E. J.; FAWCETT, D. Modelling the crystal structure of a $30 \mathrm{~nm}$ sized particle based hydroxyapatite powder synthesised under the influence of ultrasound irradiation from X-ray powder diffraction data. American Journal of Materials Science, v. 3, n. 4, p. 84-90, 2013.

CHARRIÈRE, E.; LEMAITRE, J.; ZYSSET, P. Hydroxyapatite cement scaffolds with controlled macro porosity: fabrication protocol and mechanical properties. Biomaterials, v. 24, n. 5, p. 809-817, 2003.

CHEN, X. et al. Regenerated ombyx silk solutions studied with rheometry and FTIR. Polymer, v. 42, n. 25, p. 9969-9974, 2001.

CHOI, H.W. et al. Surface modification of hydroxyapatite nanocrystals by grafting polymers containing phosphonic acid groups. Journal of Colloid and Interface Science, v. 304, n. 1, p. 277-281, 2006.

CLARKE, B. Normal bone anatomy and physiology. Clinical Journal of the American Society of Nephrology, v. 3, n. Supplement 3, p. S131-S139, 2008.

DALTON, S. Paget's disease. 2017. Disponível em: <https://diseasesandconditions.net/pagets-disease/>. Acesso em: 19 jun. 2018.

DU, C. et al. Novel silk fibroin/hydroxyapatite composite films: structure and properties. Materials Science and Engineering: C, v.29, n. 1, p. 62-68, 2009. 
DZIADEK, M., STODOLAK-ZYCH, E., CHOLEWA-KOWALSKA, K. Biodegradable ceramic-polymer composites for biomedical applications: a review. Materials Science and Engineering: C, v. 71, p. 1175-1191, 2017.

EVANS, E. J. Toxicity of hydroxyapatite in vitro: the effect of particle size. Biomaterials, v. 12, n. 6, p. 574-576, 1991.

FAN, C. et al. Facile fabrication of nano-hydroxyapatite/silk fibroin composite via a simplified coprecipitation route. Journal of Materials Science, v. 45, n. 21, p. 5814-5819, 2010.

GELB, H. et al. In vivo inflammatory response to polymethylmethacrylate particulate debris: effect of size, morphology, and surface area. Journal of Orthopaedic Research, v. 12, n; 1, p. 83-92, 1994.

GHOLIPOURMALEKABADI, M. et al. In vitro and in vivo evaluations of three-dimensional hydroxyapatite/silk fibroin nanocomposite scaffolds. Biotechnology and Applied Biochemistry, v. 62, n. 4, p.441-450, 2015.

GIL, E. S. et al. Mechanical improvements to reinforced porous silk scaffolds. Journal of Biomedical Materials Research, v. 99, n. 1, p. 16- 28, 2011.

GLASS, S. J., EWSUK, K. G. Ceramic powder compaction. MRS Bulletin, v. 22, n. 12, p. 24-28, 1997.

GREENWALD, A. S. et al. Bone-graft substitutes: facts, fictions, and applications. Journal of Bone and Joint Surgery, v. 83, p. 98-103, 2001.

HAIDER, A. et al. Recent advances in the synthesis, functionalization and biomedical applications of hydroxyapatite: a review. The Royal Society of Chemistry, v. 7, n. 13, p. 7442-7458, 2017.

HOFMANN, S.; et al. Silk fibroin as an organic polymer for controlled drug delivery. Journal of Controlled Release, v. 111, n. 1-2, p. 219-227, 2006.

HU, X., KAPLAN, D., CEBE, P. Effect of water on the thermal properties of silk fibroin. Thermochimica Acta, v. 461, n. 1-2, p. 137-144, 2007.

IBRAHIM, M. Z. et al. Biomedical materials and techniques to improve the tribological, mechanical and biomedical properties of orthopedic implants: A review article. Journal of Alloys and Compounds, v. 714, p. 636-667, 2017.

JIANG, J. et al. Hydroxyapatite/regenerated silk fibroin scaffold-enhanced osteoinductivity and osteoconductivity of bone marrow-derived mesenchymal stromal cells. Biotechnology Letters, v. 35, n. 4, p. 657-661, 2013.

JUDAS, F. et al. Estrutura e dinâmica do tecido ósseo. [S.1.: s.n.], 2012.

KAO, S. T.; SCOTT, D. D. A Review of bone substitutes. Oral and Maxillofacial Surgery 
Clinics of North America, v. 19, n. 4, p. 513-521, 2007.

KIM, H. S.; KIM, J. T.; JUNG, Y. J. Preparation of a porous chitosan/fibroin-hydroxyapatite composite matrix for tissue engineering. Macromolecular Research, v. 15, n. 1, p. 65-73, 2007.

KIM, H.M. et al. T. The mechanism of biomineralization of bone-like apatite on synthetic hydroxyapatite: an in vitro assessment. Journal of the Royal Society Interface, v. 1, n. 1, p. 17-22, 2004.

KLAWITTER, J. J.; HULBERT, S. F. Application of porous ceramics for the attachment of load bearing internal orthopedic applications. Journal of Biomedical Materials Research, v. 5, n. 6, p.161-229, 1971.

KMITA, A. R et al. FTIR and XRD investigations on the thermal stability of hydroxyapatite during hot pressing and pressureless sintering processes. Journal of Molecular Structure, v. 744, p. 653-656, 2005.

KOH, L.-D. et al. Structures, mechanical properties and applications of silk fibroin materials. Progress in Polymer Science, v. 46, p. 86-110, July 2015.

KOKUBO, T.; KIM, H. M.; KAWASHITA, M. Novel bioactive materials with different mechanical properties. Biomaterials, v. 24, n. 13, p. 2161-2175, 2003.

KOKUBO, T.; TAKADAMA, H. How useful is SBF in predicting in vivo bone bioactivity? Biomaterials, v. 27, n. 15, p. 2907-2915, 2006.

KOMLEV, V.S.; BARINOV, S.M. Porous hydroxyapatite ceramics of bi modal pore size distribution. Journal of Materials Science: Materials in Medicine, v. 13, n. 3, p. 295-299, 2002.

KOUTSOPOULOS, S. Synthesis and characterization of hydroxyapatite crystals: a review study on the analytical methods. Journal of Biomedical Materials Research, v. 62, n. 4, p. 600-612, 2002.

LANDI, E. et al. Carbonated hydroxyapatite as bone substitute. Journal of the European Ceramic Society, v.23, n. 15, p. 2931-2937, 2003.

LAQUERRIERE, P. et al. Importance of hydroxyapatite particles characteristics on cytokines production by human monocytes in vitro. Biomaterials, v. 24, n. 16, p. 2739-2747, 2003.

LIM, S. et al. Comparison study of porous calcium phosphate blocks prepared by piston and screw type extruders for bone scaffold. Tissue Engineering and Regenerative Medicine, v. 9, n. 1, p. 51-55, 2012.

LIU, L. et al. Preparation and characterization of nano-hydroxyapatite/silk fibroin porous scaffolds. Journal of Biomaterials Science: Polymer Edition, v. 19, n. 3, p. 325-338, 2008.

MANDAL, B. B. et al. High-strength silk protein scaffolds for bone repair. Proceedings of the National Academy of Sciences, v. 109, n. 20, p. 7699-7704, 2012. 
MCNAMARA, S.L. et al. Silk as a biocohesive sacrificial binder in the fabrication of hydroxyapatite load bearing scaffolds. Biomaterials, v. 35, n. 25, p. 6941-6953, 2014.

MELKE, J. et al. Silk fibroin as biomaterial for bone tissue engineering. Acta Biomaterialia, v. 31, p. 1-16, 2016.

MOBASHERPOUR, I. et al. Synthesis of nanocrystalline hydroxyapatite by using precipitation method. Journal of Alloys and Compounds, v. 430, n. 1-2, p. 330-333, 2007.

MOTTAGHITALAB, F. et al. Silk as a potential candidate for bone tissue engineering. Journal of Controlled Release, v. 215, p. 112- 128, 2015.

MURUGAN, R.; RAMAKRISHNA, S. Bioresorbable composite bone paste using polysaccharide based nano hydroxyapatite. Biomaterials, v. 25, n. 17, p. 3829-3835, 2004.

NAZAROV, R.; JIN, H. J.; KAPLAN, D. L. Porous 3-D scaffolds from regenerated silk fibroin. Biomacromolecules, v. 5, n. 3, p. 718-726, 2004.

ORYAN, A.; ALIDADI, S. Bone regeneration. Iran: AvidScience: 2017.

PADILLA, S.; IZQUIERDO-BARBA, I.; VALLET-REGÍ, M. High specific surface area in nanometric carbonated hydroxyapatite. Chemistry of Materials, v. 20, n. 19, p. 5942-5944, 2008.

PANG, Y.X.; BAO, X. Influence of temperature, ripening time and calcination on the morphology and crystallinity of hydroxyapatite nanoparticles. Journal of the European Ceramic Society, v. 23, n. 10, p. 1697-1704, 2003.

PARK, H. J. et al. Fabrication of 3D porous silk scaffolds by particulate (salt/sucrose) leaching for bone tissue reconstruction. International Journal of Biological Macromolecules, v. 78, p. 215-223, 2015.

PERDIGÃO, A.L. et al. Synthetic hydroxyapatite, silk fibroin and hyaluronic acid in bone regeneration in an experimental model. In: WORLD BIOMATERIALS CONGRESS, 10., 2016, Montréal. Proceedings..., Red Hook: Curran Associates, 2016.

PRAKASAM, M. et al. Fabrication, properties and applications of dense hydroxyapatite: a review. Journal of Functional Biomaterials, v. 6, n. 4, p. 1099-1140, 2015.

PRECHEUR, H. V. Bone graft materials. Dental Clinics of North America, v. 51, n. 3, p. 729-746, 2007.

QI, X. et al. Q. Preparation of chitosan/silk fibroin/hydroxyapatite porous scaffold and its characteristics in comparison to bi-component scaffolds. Journal of Biomedical Materials Research: Part A, v.102, n. 2, p. 366-372, 2014.

QI, M. L. et al. Hydroxyapatite fibers: a review of synthesis methods. The Journal of the Minerals, Metals \& Materials Society, v. 69, n. 8, p. 1354-1360, 2017a. 
QI, Y. et al. A Review of structure construction of silk fibroin biomaterials from single structures to multi-level structures. International Journal of Molecular Sciences, v. 18, n. 3, p. 1- 21, $2017 b$.

RAMAKRISHNA, S. et al. Biomedical applications of polymer-composite materials: a review. Composites Science and Technology, v. 61, n. 9, p. 1189-1224, 2001.

RATNAYAKE, J. T. B.; MUCALO, M.; DIAS, G. J. Substituted hydroxyapatites for bone regeneration: a review of current trends. Journal of Biomedical Materials Research Part B: Applied Biomaterials, v. 105, n. 5, p. 1285-1299, 2016.

RATNER, B. D. et al. Biomaterials science: an introduction to materials in Medicine. 3rd ed., Canada: Academic Press, 2012.

REAL, R. P. P. et al. A New method to produce macropores in calcium phosphate cements. Biomaterials, v. 23, n. 17, p. 3673-3680, 2002.

REBELO, R.; FERNANDES, M.; FANGUEIRO, R. Biopolymers in medical implants: a brief review. Procedia Engineering, v. 200, p. 236-243, 2017.

REPETTO, G.; PESO, A.; ZURITA, J. L. Neutral red uptake assay for the estimation of cell viability/cytotoxicity. Nature Protocol, v. 3, n. 7, p. 1125-1131, 2008.

ROCKWOOD, D. N., et al. Materials fabrication from Bombyx mori silk fibroin. Nature Protocols, v. 6, p. 1612 - 1631, 2011.

ROGERO, S. O. et al. Teste in vitro de citotoxicidade: estudo comparativo entre duas metodologias. Materials Research, v. 6, n. 3, p. 317-320, 2003.

SABIR, M. I.; XU, X.; LI, L. A Review on biodegradable polymeric materials for bone tissue engineering applications. Journal of Material Science, v. 44, n. 21, p. 5713-5724, 2009.

SAILAJA, G. S. et al. Biomimetic approaches with smart interfaces for bone regeneration. Journal of Biomedical Science, v. 23, n. 1, p. 77- 90, 2016.

SEPULVEDA, P. et al. Properties of highly porous hydroxyapatite obtained by the gelcasting of foams. Journal of the American Ceramic Society, v. 83, p. 3021-3024, 2000.

SHOJAI, M. S. et al. Synthesis methods for nanosized hydroxyapatite with diverse structures. Acta Biomaterialia, v. 9, p. 7591-7621, 2013.

SIERRA, S. A. et al. Interconnected porosity analysis by 3D X-ray microtomography and mechanical behavior of biomimetic organic-inorganic composite materials. Materials Science and Engineering C, v. 80, p. 45-53, 2017.

SIONKAWSKA, A. Current research on the blends of natural and synthetic polymers as new biomaterials: review. Progress in Polymer Science, v. 36, n. 9, p. 1254- 1276, 2011.

ŚLÓSARCZYK, A.; PASZKIEWICZ, Z.; PALUSZKIEWICZ, C. FTIR and XRD evaluation of carbonated hydroxyapatite powders synthesized by wet methods. Journal of Molecular 
Structure, v. 744-747, p. 657-661, 2005.

STEVENS, M. M. Biomaterials for bone tissue engineering. Materials Today, v. 11, n. 5, p. 18-25, 2008.

TEIMOURI, A. et al. Preparation, characterization, degradation and biocompatibility of different silk fibroin based composite scaffolds prepared by freeze-drying method for tissue engineering application. Polymer Degradation and Stability, v. 121, p. 18-29, 2015.

WALLIN, R. F.; ARSCOTT, E. F. A Practical guide to ISO 10993-5: cytotoxicity. Medical Device and Diagnostic Industry, v. 20, p. 96-98, 1998.

WANG, L.; LI, C. Preparation and physicochemical properties of a novel hydroxyapatite/chitosan-silk fibroin composite. Carbohydrate Polymers, v. 68, n. 4, p. 740$745,2007$.

WANG, L.; NEMOTO, R.; SENNA, M. Changes in microstructure and physico-chemical properties of hydroxyapatite-silk fibroin nanocomposite with varying silk fibroin content. Journal of the European Ceramic Society, v.24, n. 9, p.2707-2715, 2004.

YOUSAFZAI, M. I am Malala: the girl who stood up for education and was shot by the taliban. New York: Little, Brown \& Company, 2013.

ZAKHAROV, N. A. et al. Synthesis and properties of calcium hydroxyapatite/silk fibroin organomineral composites. Inorganic Materials, v. 53, n. 3, p. 333-342, 2017.

ZHANG, H. et al. Thermal properties of Bombyx mori silk fibers. Journal of Applied Polymer Science, v. 86, n. 8, p. 1817-1820, 2002.

ZHAO, H.; LIANG, W. A Novel comby scaffold with improved mechanical strength for bone tissue engineering. Materials Letters, v. 194, p. 220-223, 2017. 